UNIVERSIDADE ESTADUAL PAULISTA

FACULDADE DE MEDICINA VETERINÁRIA E ZOOTECNIA

INTERFERÊNCIA DOS ANTICORPOS COLOSTRAIS EM BEZERROS VACINADOS AOS DOIS, QUATRO E SEIS MESES DE IDADE, FILHOS DE VACAS REVACINADAS CONTRA A RAIVA BOVINA

OTÁVIO AUGUSTO FILHO

Botucatu - SP

2010 
UNIVERSIDADE ESTADUAL PAULISTA

FACULDADE DE MEDICINA VETERINÁRIA E ZOOTECNIA

INTERFERÊNCIA DOS ANTICORPOS COLOSTRAIS EM BEZERROS VACINADOS AOS DOIS, QUATRO E SEIS MESES DE IDADE, FILHOS DE VACAS REVACINADAS CONTRA A RAIVA BOVINA

\section{OTÁVIO AUGUSTO FILHO}

Tese apresentada junto ao Programa de Pós-Graduação em Medicina Veterinária para obtenção do título de Doutor.

Orientadora: Profa. Dra. Jane Megid

Botucatu - SP

2010 
FICHA CATALOGRÁFICA ELABORADA PELA SEÇÃO TÉCNICA DE AQUISIÇÃO E TRATAMENTO DA INFORMAÇÃO

DIVISÃO TÉCNICA DE BIBLIOTECA E DOCUMENTAÇÃO - CAMPUS DE BOTUCATU - UNESP BIBLIOTECÁRIA RESPONSÁVEL: Selma Maria de Jesus

Augusto Filho, Otávio.

Interferência dos anticorpos colostrais em bezerros vacinados aos dois, quatro e seis meses de idade, filhos de vacas revacinadas contra a raiva bovina./ Otávio Augusto Filho. - Botucatu, 2010.

Tese (doutorado) - Universidade Estadual Paulista, Faculdade de Medicina Veterinária e Zootecnia, Botucatu, 2010

Orientador: Jane Megid

Assunto CAPES: 50502050

1. Bovino - Aspectos imunológicos $\quad$ 2. Raiva

Palavras-chave:Anticorpos colostrais; Bezerros; Sorologia; Vacina antirrábica 
Nome do autor: Otavio Augusto Filho

Título: Interferência dos anticorpos colostrais em bezerros vacinados aos dois, quatro e seis meses de idade, filhos de vacas revacinadas contra a raiva bovina.

\section{COMISSÃO EXAMINADORA}

Profa. Dra $^{\mathrm{a}}$. Jane Megid

Presidente e Orientadora

Departamento de Higiene Veterinária e Saúde Pública

FMVZ - UNESP - Botucatu

Prof. Dr. José Paes de Almeida Nogueira Pinto

Membro

Departamento de Higiene Veterinária e Saúde Pública

FMVZ - UNESP - Botucatu

Prof. Dr. Antônio Carlos Paes

Membro

Departamento de Higiene Veterinária e Saúde Pública

FMVZ - UNESP - Botucatu

Pesq. Cient. Dr. Avelino Albas

Membro

Secretaria de Agricultura do estado de São Paulo

APTA - Presidente Prudente

Profa. Dra . Luzia Helena Queiroz

Membro

Departamento de Apoio, Produção e Saúde Animal

FMVZ - UNESP - Araçatuba

Data da Defesa: 12 de abril de 2010 
"Ninguém sabe tudo, assim como ninguém ignora tudo. O saber começa com a consciência do saber pouco. É sabendo que se sabe pouco que uma pessoa se prepara para saber mais... O homem, como um ser histórico, inserido num permanente movimento de procura, faz e refaz constantemente o seu saber."

Paulo Freire 


\section{Dedicatória}


Alo meu pai, Otávio Alugusto, e sua esposa Mariluci que souberam, apesar dos sacrificios, assumir a ausência prolongada, pelos conselhos e pelo carinho, a quem devo esta oportunidade.

As minhas mães Odete Siuf Caltheng Alugusto (in memorian) e Nely Xaria Barros (in memorian) que apesar de pouco tempo de convivio, fizeram parte da minha vida.

Zlos meus irmãos Dedro e Xarcele, meus cunhados e sobrinhos, pelo carinho e apoio.

A minha mãe de coração Ana Fresneda, seu esposo José Ramiro pelo carinho, amizade, compreensão exemplo de vida.

Zlos meus amigos e compadres Luiz Henrique Xachado e Fabiola Zann pelo carinho e amizade durante todos estes anos.

Zlo grande amigo e companheiro de trabalho José Eduardo Bosco, sempre presente nos momentos dificeis, a quem devo muito.

Zl amiga Satie Katagiri, pelas ajudas no decorrer deste trabalho.

Zl Lucinéia Geronutti, amiga de graduação, residência, Dós graduação e sempre.

Zlos meus cães e fieis companheiros Juca, Carlinhos e Samba (in memorian). 
Zlgradecimentos 


\section{Zlgradeço}

A Deus, pela minha vida e oportunidade de estar realizando mais uma etapa em minhajornada..

A minha orientadora, Jane Xegid, exemplo de vida a ser seguido tanto pelo seu profissionalismo, quanto pela amizade, confiança, experiência e dedicação.

Zlos docentes do Departamento de Higiene Veterinária e Saúde Dública, Antonio Carlos Paes, Xarcio Garcia Ribeiro, Hélio Langoni, Rafael Modolo e Paulo Domingues.

Is biólogas Luzia Fátima Alves Xartorelli e Znna Paula A.G. Kataoka do laboratório de raiva do Centro de Controle de Zoonoze de São Paulo (CCZ), assim como ao Zootecnista João Ratti Junior da FXMZ - Fazenda São Xanoel, pela valiosa colaboração no desenvolvimento desse trabalho de pesquisa.

A bibliotecária Rosemary Cristina e aos funcionários da Biblioteca Central da UNESD do Campus de Botucatu, pelas orientações e pela elaboração da ficha catalográfica.

Is amigas de Dós Graduação Suzan e Camila pelo companherismo e dedicação.

Al todos que contribuiram de forma direta e indireta para a realização deste trabalho. 
LISTA DE ABREVIATURAS E SÍMBOLOS

RESUMO

1. INTRODUÇÃO

2. REVISÃO DE LITERATURA _ 20

2.1. Definição ........................................................................... 21

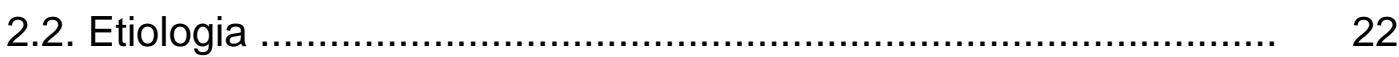

2.3. Patogenia e resposta imune antirrábica .................................... 23

2.4. Sinais clínicos ....................................................................... 25

2.5. Epidemiologia ................................................................. 26

Controle e Profilaxia ................................................................ $\quad 30$

3. OBJETIVO _ 44

4. MATERIAL E MÉTODOS_ $\quad 46$

4.1. Seleção dos animais .......................................................... 47

4.2. Delineamento experimental.................................................... 47

4.2.1. Grupo de vacas revacinadas ............................ 48

4.2.2. Lotes de bezerros................................................... 48

4.3. Colheita de material................................................................. 48

4.3.1. Seleção e colheita de sangue dos animais........................ 48

4.3.2. Soroneutralizacão em cultura celular (SN)....................... 49

4.3.3. Imunofluorescência direta (IFD)....................................... 49

4.4. Análise estatística .................................................................. 50

5. RESULTADOS 51

6. DISCUSSÃO__ 61

$\begin{array}{ll}\text { 7. CONCLUSÕES } & 73\end{array}$

$\begin{array}{ll}\text { 8. REFERÊNCIAS } & 75\end{array}$

ANEXOS $\quad 89$

ARTIGO I

Importance of antirabies revaccination for an adequate antirabies protection in newborn.

\section{ARTIGO II}

Vaccinal immune response and interference of colostral antibodies in calves vaccinated at 2, 4 and 6 month of age born from revaccinated females 


\section{Lista de Abreviaturas e Simbolos}




\section{LISTA DE ABREVIATURAS E SÍMBOLOS}

\begin{tabular}{|c|c|}
\hline$\%=$ & Porcentagem \\
\hline$\geq=$ & maior/igual \\
\hline$A c=$ & Anticorpos \\
\hline $\operatorname{AcSN}=$ & Anticorpos soroneutralizantes \\
\hline et al. = & e colaboradores \\
\hline $\lg =$ & Imunoglobulina \\
\hline $\lg G=$ & Imunoglobulina G \\
\hline $\lg M=$ & Imunoglobulina M \\
\hline $\lg A=$ & Imunoglobulina A \\
\hline$m L=$ & Mililitro \\
\hline SNC = & Sistema Nervoso Central \\
\hline
\end{tabular}


Resumo 
AUGUSTO FILHO, O. Interferência dos anticorpos colostrais em bezerros vacinados aos dois, quatro e seis meses de idade, filhos de vacas revacinadas contra raiva bovina. Botucatu, 2010. --- p. Tese (Doutorado) Faculdade de Medicina Veterinária e Zootecnia, Campus de Botucatu, Universidade Estadual Paulista.

\section{RESUMO}

Bezerros nascidos de vacas revacinadas contra raiva no terço final de gestação foram vacinados aos dois, quatro e seis meses de idade e revacinados 30 dias após. Os títulos de anticorpos (Ac) foram mensurados nas mães e em seus descendentes 48 horas após o parto. Os bezerros foram separados em quatro lotes com dez animais, sendo representados por bezerros não vacinados, vacinados com dois meses, quatro meses e seis meses de idade. O título de Ac antirrábicos nos bezerros dos diferentes grupos foi avaliado mensalmente e 15 dias pós vacinação e revacinação até completarem 12 meses de vida. Todas as vacas apresentaram titulo de anticorpos antirrábicos soroneutralizantes (AcSN) superiores a 0,5UI/mL 48 horas após o parto. Anticorpos transferidos pelo colostro com títulos semelhantes ao materno foram observados em todos os bezerros estudados 48 horas após o nascimento. Títulos de AcSN superiores a $0,5 \mathrm{UI} / \mathrm{mL}$ se mantiveram até o $5^{\circ}$ mês nos bezerros vacinados aos dois meses sendo que nos demais lotes houve queda nos títulos a partir do $3^{\circ}$ mês de vida apresentando um período de desproteção decorrente de queda de anticorpos colostrais superior ao grupo vacinado aos dois meses de idade. Nenhum dos grupos de bezerros estudados apresentou resposta sorológica satisfatória a primo vacinação, porém, todos apresentaram resposta adequada após a revacinação. O estudo demonstrou que é recomendável a vacinação antirrábica em bezerros aos dois meses de idade independentemente do estado vacinal materno seguida de revacinação 30 dias após, e ao completarem 12 meses de vida.

Palavras-chave: Vacina antirrábica, Bezerros, Anticorpos colostrais, Sorologia. 
Abstract 
AUGUSTO FILHO, O. Interference of colostral antibodies in calves vaccinated at two, four and six months of age, born from cows revaccinated against rabies. Botucatu, 2010. --- p. Tese (Doutorado) Faculdade de Medicina Veterinária e Zootecnia, Campus de Botucatu, Universidade Estadual Paulista.

\section{ABSTRACT}

Calves born from cows revaccinated against rabies in the final third of pregnancy were vaccinated at two, four and six months of age and revaccinated 30 days later. Seraneutralizing antibody titers (AcSN) against rabies were measured in mothers and their calves 48 hours after delivery. The calves were separated into four groups of 10 animals, represented by non-vaccinated and vaccinated calves with two months, four months and six months of age. The AcSN titers was evaluated monthly and 15 days after vaccination and revaccination until 12 months of life in each group. All cows had AcSN greater than $0,5 \mathrm{UI} / \mathrm{mL} 48$ hours after delivery. Antibodies trasnferred by colostrum with similar titers were observed in all calves studied 48 hours after birth. AcSN titers higher than $0,5 \mathrm{UI} / \mathrm{mL}$ remained to the 5 th month in calves vaccinated at two month of age in contrast to the others groups that presented decrease of AcSN begining at 3th month of age until 30 days after first vaccination representing a longer period of lack of protection comparatively to the group vaccinated at two month of age. Absence of satisfatory antibody response was observed in all groups after the first vaccination, however, all calves had an adequate response after revaccination. The study demonstrated that antirabies vaccination can be recommended in calves at two months of age regardless of vaccination status of mothers being mandatory the revaccination 30 days after and at 12 months of life.

Keywords: Rabies vaccines, calves, colostral antibodies, serology 
Nos últimos anos tem-se notado um aumento no número de casos de raiva bovina no Estado de São Paulo. Por esse motivo instituiu-se a obrigatoriedade da vacinação antirrábica em áreas de risco conforme legislação estadual SSA- 29 de 24 de setembro de 2001, estabelecendo a vacinação de forma compulsória em áreas em focos e perifocos da doença numa área de até $12 \mathrm{~km}$ de raio, além do controle dos morcegos hematófagos e educação sanitária (SÃO PAULO, 2002).

A vacinação contra raiva induz a produção de anticorpos (Ac) séricos que persistem por um período prolongado e que pode ser transmitido aos filhos através do colostro, aspecto relevante quando da primovacinação dos animais jovens.

Em experimentos anteriores realizados por GERONUTTI (2002) com vacas primo vacinadas, observou-se que bezerros a partir de dois meses de idade responderam à vacinação antirrábica, independentemente do estado vacinal materno, condicionada ao reforço vacinal 30 dias após a primovacinação, sendo sugerido a utilização deste esquema vacinal em regiões epidêmicas para a enfermidade. Questiona-se a interferência da revacinação materna na vacinação de bezerros nesta mesma faixa etária, aspecto que impossibilitaria a aplicação do protocolo sugerido anteriormente o qual a preconiza a vacinação antirrábica a partir do $3^{\circ}$ mês de idade.

O presente estudo avaliou a resposta à vacinação antirrábica de bezerros filhos de mães revacinadas contra a raiva, vacinados aos dois, quatro e seis meses de idade com especial ênfase a possível interferência dos Ac colostrais, bem como a efetividade da vacinação mais precoce. 
2. Revisão de Literatura 


\subsection{DEFINIÇÃO}

A raiva é uma doença de origem viral, caracterizada por uma encefalite severa, de notificação obrigatória que pode acometer todos os mamíferos, inclusive o homem. Reveste-se da maior importância epidemiológica por apresentar letalidade de 100\% em animais, além de ser uma doença passível de eliminação no seu ciclo urbano e rural através de medidas eficientes de prevenção (BRASIL, 2006).

É considerada uma das zoonoses de maior importância em saúde pública, não só pela evolução drástica e letal, como também pelo elevado custo social e econômico. Numerosas variantes do vírus já foram identificadas, sendo que no Brasil, foram encontradas quatro variantes: variante 2, própria dos cães; variante 3, própria do morcego hematófago Desmodus rotundus; variante 4 própria do morcego insetívoro Tardarida brasiliensis; e variante 6, própria do morcego insetívoro Lasiurus cinereus. Estudos realizados com amostras isoladas nos últimos anos, no Brasil, permitiram a proposição de um ciclo epidemiológico da raiva, no qual há uma estreita interrelação entre os quatro ciclos clássicos do vírus rábico, sendo estes representados como ciclos aéreo, silvestre, rural e urbano (RIET-CORRÊA et al., 2007).

A doença apresenta uma forma clínica paralítica, que predomina em bovinos, e uma forma predominantemente furiosa nos carnívoros. É considerada uma das doenças neurológicas mais prevalentes na espécie bovina sendo no Brasil transmitida principalmente pelo morcego hematófago Desmodus rotundus (BARROS et al., 2006).

Os herbívoros são hospedeiros acidentais do vírus da raiva, pois, apesar de participarem da cadeia epidemiológica da raiva rural, somente contribuem como sentinelas à existência do vírus. Sua participação nesse processo 
restringe-se ao óbito do animal, não havendo envolvimento no processo de transmissão a outras espécies, salvo quando de forma acidental (BARROS et al., 2006).

\subsection{ETIOLOGIA}

O vírus da raiva é classificado na ordem Mononegavirales, família Rhabdoviridae, gênero Lyssavirus. Possui um genoma de RNA de fita simples, linear e não segmentado de polaridade negativa e envolvido por uma complexa ribonucleoproteína. Apresenta-se sob forma de projétil de revolver com 45 a $100 \mathrm{~nm}$ de diâmetro e 100 a $430 \mathrm{~nm}$ de comprimento variando com a amostra considerada (QUINN et al., 2005).

O vírus da raiva foi classificado originalmente em 7 genotipos sendo 0 genotipo-1 o vírus clássico, que compreende amostras vacinais e amostras de vírus de rua isoladas de animais domésticos e silvestres (WUNNER, 2007).

É constituído essencialmente de cinco proteínas principais: uma grande RNA-polimerase RNA-dependente (L), uma glicoproteína de superfície (G), uma nucleoproteína $(\mathrm{N})$, uma proteína componente da polimerase viral $(P)$ e uma proteína matriz (M). A glicoproteína G forma os polímeros superficiais que interagem com os receptores da célula hospedeira, tendo um importante papel na patogenia da raiva já que é responsável pela adesão do vírus a membrana da célula alvo e a fusão entre a membrana celular e o vírus durante o processo de endocitose (ACHKAR et al., 2007; ROSS et al., 2008).

O vírus clássico, genótipo-1, é envelopado, sensível aos agentes químicos (éter, clorofórmio, ácidos e álcalis fortes). Sua resistência fora do hospedeiro é baixa, sendo rapidamente inativado a temperaturas altas, sendo destruído a $50^{\circ} \mathrm{C}$ durante 15 minutos. É sensível ao dessecamento, luz solar, radiação ultravioleta, agentes físicos (calor, luz ultravioleta) e às condições ambientais como temperatura excessiva. O vírus se mantém estável por longos 
períodos a $4^{\circ} \mathrm{C}$, e por vários anos quando conservado a $-20^{\circ} \mathrm{C}$ em tecidos mergulhados em glicerina tamponada. $\mathrm{A}-70^{\circ} \mathrm{C}$ ou temperaturas mais baixas, $\mathrm{O}$ vírus se mantém viável indefinidamente (FAUQUET et al., 2004; QUINN et al., 2005; ACHKAR et al., 2007).

\subsection{PATOGENIA E RESPOSTA IMUNE ANTIRRÁBICA}

A transmissão da raiva se dá através da penetração do vírus presente na saliva do animal infectado, principalmente por meio da mordedura e, raramente pela arranhadura e lambedura de pele com solução de continuidade ou de mucosa integra. Os herbívoros podem contrair a raiva por mordedura de um cão ou animal silvestre infectado, no entanto em bovinos e eqüinos a enfermidade é normalmente transmitida por mordeduras de morcegos hematófagos infectados com o vírus rábico, sendo principalmente o Desmodus rotundus (RIET-CORRÊA et al., 2007).

Uma vez inoculado no novo hospedeiro, ocorre a replicação do vírus da raiva inicialmente nas células musculares, próximas ao local de inoculação até que atinjam concentrações suficientes para alcançar as terminações nervosas, sendo este período de replicação extra neural responsável pelo período de incubação relativamente longo da raiva, quando comparado com outras infecções virais (JACKSON, 2007).

Ao contrário de muitos vírus que causam infecção aguda, o vírus da raiva consegue evadir-se as defesas imunes do hospedeiro por um longo período; face ao seu neurotropismo, sua amplificação no local de inoculação produz quantidade de vírus suficiente para chegar às terminações nervosas, porém insuficiente para ser antigênica (ZANETTI, 2003).

Nas junções neuromusculares o vírus rábico, através da glicoproteína (G) presente em seu envelope, se liga especificamente ao receptor nicotínico da acetilcolina (AchR) considerado a principal porta de entrada do vírus para os neurônios (JACKSON, 2007). A seguir, o vírus atinge os nervos periféricos, 
seguindo um trajeto centrípeto, em direção ao sistema nervoso central (SNC), e segue através do fluxo axoplasmático retrógrado diretamente através das fibras nervosas sem liberação para o meio extracelular (JACKSON, 2007).

Ao penetrar nos neurônios, o vírus da raiva torna-se protegido da ação dos Ac, das células do sistema imune e da ação dos intérferons, responsáveis pela resposta imune inespecífica. A ausência desta resposta é reforçada pela capacidade do vírus rábico de induzir a uma imunossupressão periférica, tendo como conseqüência, o escape do vírus da ação dos Ac, facilitando a invasão ao SNC (LAFON, 2007).

Ao atingir o SNC, o vírus rábico apresenta rápida replicação em diferentes locais, sendo que o local de eleição varia de acordo com a espécie animal e talvez com a variante viral. Assim, nos cães e gatos o local onde é encontrado em maior quantidade é o hipocampo (Corno de Amon) e giro denteado (neurônios piramidais), nos eqüinos é a medula espinhal e nos bovinos o cerebelo (Células de Purkinje) (ZANETTI, 2003; JACKSON, 2007).

A partir da intensa replicação no SNC, o vírus se dissemina via nervos periféricos de forma centrífuga para os tecidos não neuronais, distribuindo-se por todo o organismo. Antígenos virais já foram detectados em células da epiderme, folículos pilosos, retina, córnea, pulmões, coração, rins, bexiga, folículo piloso e glândulas salivares, sendo eliminado pela saliva, principal mecanismo de disseminação e perpetuação do mesmo na natureza (ZANETTI, 2003; JACKSON, 2007).

As células apresentadoras de antígeno (macrófagos, células dendríticas, células de Langherans, etc.) quando entram em contato com o vírus da raiva, o fagocitam e o processam para apresentação para as células imunes. Esta apresentação é fundamental para a ativação dos linfócitos T auxiliares, que vão produzir diferentes citocinas; estas ativam diferentes células implicadas na eliminação direta do vírus ou de células infectadas e auxiliam na produção de anticorpos pelos linfócitos $B$, o que na infecção natural tem o seu inicio após o aparecimento dos sintomas clínicos (LAFON, 2007) e em resposta a quantidade maciça de antígeno viral (ZANETTI, 2003). 
$\mathrm{Na}$ infecção natural, a estimulação dos linfócitos B para produção de Ac acontece tardiamente, após o aparecimento dos sintomas. A atividade principal dos Ac é bloquear o vírus extracelular, antes que ele encontre o receptor das células musculares, impedindo sua propagação no local da infecção e sua progressão para o sistema nervoso central (LAFON, 2007). A resposta imune celular talvez seja o mecanismo imunológico mais importante contra o vírus da raiva. Os linfócitos $T$ participam da proteção de diferentes maneiras: estimulando, através dos linfócitos $T$ auxiliares, as células B a produzirem Ac; como efetoras de imunidade, na forma de células $T$ citotóxicas, lisando as células infectadas; induzindo a síntese de substâncias mediadoras de estimulação de diferentes células e como células de memória imunológica (LAFON, 2007).

A possibilidade de neutralização da capacidade infecciosa viral ocorre, portanto, após a invasão do SNC e, neste momento, a doença já adquiriu uma forma irreversível, e o título de anticorpos neutralizantes ( $\mathrm{AcN}$ ) contra o vírus permanece baixo até a fase terminal da doença, atingindo seu pico máximo próximo da morte (LAFON, 2007).

\subsection{SINAIS CLÍNICOS}

O período de incubação é variável, porém normalmente varia entre 25 e 90 dias. Depende da susceptibilidade do animal, do estado imunitário, da idade, do local da mordedura, da variante viral e da quantidade de vírus inoculado (KOTAIT, 2009).

Em herbívoros a forma mais comum é a raiva paralítica, porem a forma furiosa também pode ser observada, levando o animal a investir contra outros animais e seres humanos (CALLAN \& METRE, 2004). Como sinais clínicos, primeiramente há um afastamento do animal dos demais, seguido por apatia, inapetência, podendo apresentar cabeça baixa e indiferente ao que passa ao seu redor. Pode haver aumento da sensibilidade e prurido na área de 
mordedura, mugido constante, tenesmo, hiperexcitabilidade, aumento da libido, sialorréia, e dificuldade para engolir (o que sugere que o animal esteja engasgado). Com a evolução da doença, apresenta movimentos desordenados da cabeça, tremores musculares e ranger dos dentes, midríase com ausência de reflexo pupilar, incoordenação motora, andar cambaleante e contrações musculares involuntárias. Após o decúbito não consegue mais se levantar; são observados movimentos de pedalagem, dispnéia, opstótomo, e morte por asfixia, normalmente de três a seis dias, podendo se prolongar até dez dias após o início dos sintomas clínicos (FERNANDES, 2001; LANGOHR et al., 2003; CALLAN \& METRE, 2004; PUGH, 2005).

\subsection{EPIDEMIOLOGIA}

A raiva clássica causada pelos vírus genótipo 1 está distribuída em todos os continentes, com exceção da Oceania. Alguns países Insulares como Japão, Nova Zelândia, Maldivas Barbados e Fiji, são considerados livres da doença mesmo entre os animais silvestres, considerados reservatórios naturais, porém, em certas áreas do mundo principalmente nos países em desenvolvimento, a raiva continua a ser altamente endêmica (WHO, 2008).

A raiva em animais silvestres terrestres assume papel importante nas Europa, Estados Unidos e Canadá, onde várias espécies estão envolvidas na transmissão para animais domésticos e para o homem (WHO, 2008). Na América do Norte, os reservatórios mais importantes são as raposas (Vulpes vulpes ), os raccoons ( Procyon Lotor); os skunks (Mephitis mephitis), os lobos (Canis lupus arabs, Canis latrans) e as raposas do ártico ( Alopex lagopus) . Na Europa, as raposas vermelhas (Vulpes vulpes) e o raccoon-dog (Nictereutes procyonoides) são os mais citados (KREBS et al., 2002). No Brasil há relatos esporádicos de isolamento do vírus da raiva em animais silvestres como guaxinins (Procyon cancrivorous), lobo guará (Crysocyon brachyurus), sagüi do Nordeste (Callitrix jacchus), raposa do Nordeste (Dusicyon vetulus), coati 
(Nasua nasua), gato do mato (Leopardus tigrinus), onça pintada (Panthera onça), cachorro do mato (Cerdocyon thous) (CORREA; PASSOS, 2001).

FAVORETO et al., em 2006, realizaram um levantamento epidemiológico dos casos de raiva em animais silvestres no estado do Ceará entre os anos de 1990 a 2005, onde relataram um total de 173 casos de raiva em cachorro do mato (Cerdocyon thous), 25 em sagüi do Nordeste (Callitrix jacchus) e seis em guaxinins (Procyon cancrivorous). Durante este período, em 13 dos 40 casos humanos registrados no Ceará, os animais silvestres a fonte de infecção.

Com o desmatamento, a destruição e fragmentação do habitat natural, estes animais terminam migrando para áreas urbanas e periurbanas, e ao contato com seres humanos e animais domésticos, tornam-se potenciais fonte de infecção da raiva (CARNIELI et al., 2008).

De acordo com a Organização Mundial da Saúde (OMS) 2004, o número estimado de mortes humanas causadas pela raiva ao redor do mundo é de 55.000 por ano, principalmente em áreas rurais da África (24.000 mortes) e da Ásia (31.000 mortes), representando para os governos um custo de aproximadamente 560 milhões de dólares todos os anos direcionados a profilaxia após a exposição. Nos últimos anos, após a implementação dos programas de vacinações de cães e gatos tem-se observado uma redução de casos de raiva em humanos na América do Sul e em alguns países Asiáticos (BELOTTO et al., 2005; WHO, 2006). Na Ásia e na África o cão continua sendo o mais importante reservatório e transmissor da raiva aos humanos, sendo considerado como um grave problema de saúde pública nesses Países (WHO, 2004).

No Brasil, a raiva tanto em humanos quanto em animais, está controlada em conseqüência de um Programa Nacional de Controle instituído, pelos Ministérios da Saúde e Agricultura o qual visa o tratamento profilático em humanos, vacinação em cães e gatos, diagnóstico laboratorial, educação e saúde, captura de cães errantes e vigilância epidemiológica (SCHNEIDER et al., 1996). 
Dados parciais obtidos pelo Ministério da Saúde em 2008, informam que foram registrados no Brasil 27 casos de raiva em caninos, sendo dez casos na região norte, 13 na região nordeste, quatro no centro oeste e nenhum caso registrado na região sudeste. Em referencia a raiva humana foram registrados somente três casos, sendo dois na região nordeste e um no centro-oeste (WADA, 2008). Contrariamente, em herbívoros notou-se um aumento no número de casos (BRASIL, 2009).

Segundo dados da Organização Panamericana da Saúde (OPAS, 2004) a raiva em animais de interesse econômico ocorre principalmente em países da América Latina e está relacionada à presença do morcego hematófago (Desmodus rotundus), principal reservatório do vírus da raiva para estas espécies.

As primeiras citações sobre a raiva paralítica dos herbívoros no Brasil estiveram relacionadas com o foco ocorrido no litoral do Estado de Santa Catarina entre 1906 a 1908 quando bovinos, eqüinos, suínos, ovinos e caprinos encontravam-se acometidos. Foi somente em 1911, que Antônio Carini, no Instituto Pasteur em São Paulo, diagnosticou a doença em material encefálico coletado de bovinos oriundos da Ilha de Santa Catarina.

Durante o período de 1914-1918, HAUPT e REHAAG (1925) estudaram os casos de raiva ocorridos na mesma região e confirmaram que a ocorrência da doença estava associada aos morcegos. Mais tarde, pesquisas realizadas com morcegos de diferentes áreas afetadas concluíram que a infecção com o vírus da raiva entre os morcegos hematófagos era muito mais elevada que entre as espécies frugívoras e que eram um excelente transmissor do vírus, sendo então reconhecida à importância do morcego vampiro na disseminação do vírus da raiva (QUEIROZ LIMA, 1934; TORRES; QUEIROZ LIMA, 1935).

Os morcegos têm grande importância na manutenção de circulação do vírus rábico em uma determinada área geográfica, pois esses animais possuem características ideais para a perpetuação do vírus, tais como alta densidade populacional, interações sociais com outras espécies de morcegos que freqüentam os mesmos abrigos e uma grande capacidade de 
deslocamento, podendo voar num raio de $15 \mathrm{~km}$ do seu refúgio a procura de alimentos (BRASIL, 1996).

A exploração da mata atlântica, a introdução e a expansão da pecuária bovina, no sentido litoral para o interior do país, estimularam a interiorização do morcego hematófago em busca de alimentos e a abertura de novas fronteiras agropecuárias por meio do desmatamento e implantação de pastagens povoadas por bovinos, propiciou-se uma abundante fonte de alimento para os morcegos e consequentemente o aparecimento da doença em áreas anteriormente livres do problema (MORI \& LEMOS, 1998; SILVA et al., 2000).

Os ataques dos morcegos aos bovinos, causam sérios prejuízos à pecuária, pois além da morte conseqüente a doença, os animais agredidos perdem peso devido à anemia, e apresentam lesões em diversas partes do corpo o que prejudica a qualidade do couro causando grandes perdas econômicas aos criadores (OPAS, 2001).

Segundo dados da Organização Panamericana de Saúde (OPAS, 2004), foram notificados em 2004 nos países das Américas 2797 casos de raiva em bovinos, 87\% mais casos que em 2002. Destes, 2591 (92,6\%) ocorreram na América Latina; 130 (4,6\%) na América do Norte e 76 no Caribe e Guatemala. $\mathrm{Na}$ América Latina, o Brasil notificou $60,6 \%$ dos casos, seguido pelo México, $13 \%$ e nos Andes, 8,9\%.

A ocorrência dos casos de raiva está diretamente relacionada à predominância da espécie de herbívoros criados na região (MOLINA, 2004). Dados obtidos pelo Instituto Brasileiro de Geografia e Estatística (IBGE), referem que o Brasil é o país que apresenta o maior rebanho bovino do mundo, com aproximadamente 202,2 milhões de cabeças em 2008 (JUNIOR, 2009).

De acordo com o Programa Nacional de Controle da Raiva dos Herbívoros (PNCRH), entre os anos de 1987 a 2008 foram notificados no Brasil 55.780 casos confirmados em bovinos (BRASIL, 2009).

Em 2006, foram registrados oficialmente no país 2443 casos de raiva em herbívoros sendo destes, 2221 na espécie bovina. Apesar de a doença ser 
considerada endêmica, ou seja, com incidência em todas as regiões, 55\% desses casos registrados ocorreram nos estados de Minas Gerais, Mato Grosso, Goiás e Paraná (AGRO REDE ESPECIAL, 2007), o que coincide com a distribuição do rebanho no território brasileiro, a qual mostra que a maior população bovina está concentrada na região Centro-Oeste. Nessa região, encontra-se cerca de um terço do rebanho nacional, com destaque aos Estados do Mato Grosso do Sul e Mato Grosso, sendo representantes de 13,24 e 11,07 \%, respectivamente do rebanho brasileiro. Em segundo lugar situam-se a Região Sudeste, especialmente os Estados de Minas Gerais e São Paulo, com 12,5 e 7,13 \%, respectivamente, seguidos pelos Estados do Sul, Nordeste e Norte (SEAG, 2007). Dados parciais obtidos pela Secretaria de Vigilância em Saúde em 2008, relatam que no Brasil, neste ano, foram notificados 1012 casos de raiva animal sendo que em 742 destes a espécie animal envolvida era a bovina (WADA, 2008).

Dados acumulados do Estado de São Paulo, obtidos aos anos de 2002 a 2007 reportam 1085 casos de raiva animal, destacando a espécie bovina, com 492 casos confirmados (BRASIL, 2009).

Neste mesmo Estado, em 2007 foram notificados 38 casos de raiva bovina, enquanto que dados parciais relativos a 2008, registravam no estado 91 casos, observando-se um importante aumento no número de animais infectados pelo vírus (WADA, 2008).

Devido o aumento nos casos de raiva em bovinos, a Secretaria de Agricultura e Abastecimento criaram a Coordenadoria de Defesa Agropecuária no final de 1998, responsável por definir as normas estaduais de controle da raiva nos herbívoros, onde estabelece normas para execução do projeto de controle da doença nos herbívoros, contido no capitulo III, artigo 18 o qual determina a obrigatoriedade da vacinação nas áreas de ocorrência de raiva a partir de novembro de 2001 (SÃO PAULO, 2002). 


\section{CONTROLE E PROFILAXIA}

Os esforços para controle da raiva estão ligados às estratégias regionais, que vão se adequando aos avanços dos programas nacionais, à mudança na situação da raiva, e às modificações no ecossistema dos reservatórios tanto humanos como silvestres (RUIZ \& ALVAREZ, 1998).

A raiva dos herbívoros é controlada pela vacinação de animais em áreas de foco e perifóco da doença e pelo controle das populações de morcegos hematófagos (SINDAM, 2007; BRASIL, 2009).

Atualmente o combate aos morcegos é realizado pelo método seletivo (uso de redes especiais e pastas anticoagulantes) o qual evita a destruição de espécies de morcegos insetívoros e frugívoros. A captura de morcegos deve ser realizada pela equipe da defesa sanitária animal, pois necessita de equipes estruturadas, com pessoas devidamente treinadas e imunizadas (BRASIL, 2009).

Para a vacinação, a indicação é a utilização de vacinas inativadas, que representam atualmente $95 \%$ das vacinas para bovinos comercializadas no Brasil (SIDAM, 2007; BRASIL, 2009).

O vírus da raiva, por sua natureza protéica complexa, e por possuir RNA, constitui-se em bom indutor de imunidade, quando comparado a outros vírus. Isto significa que, em condições de campo, os animais vacinados apresentam bom nível de Ac e imunidade duradoura após a vacinação (VAN KAMPEN, 1999).

O objetivo da vacinação é proporcionar imunidade, tanto em seres humanos quanto em animais, induzindo resposta específica através da imunidade humoral e celular, estimulando a produção dos AcSN contra o antígeno vacinal (SANTOS et al., 1980).

Os níveis de Ac induzidos pelas vacinas variam de acordo com a potência da cepa utilizada, o estado imunitário e nutricional dos animais, além das variantes antigênicas virais (ITO et al., 1991). 
Vários tipos de vacinas contra raiva foram utilizadas para imunização de seres humanos e animais domésticos. As vacinas mais antigas eram produzidas a partir de tecido nervoso de animais infectados pelo vírus rábico e inativados com formalina, éter e outras substâncias que destroem a partícula viral (VAN KAMPEN, 1999).

Todas as vacinas para herbívoros, atualmente comercializadas no Brasil são produzidas em culturas celulares, e inativadas de forma a se apresentarem absolutamente inócuos para todos os animais susceptíveis a doença (KOTAIT, 2009).

A vacina atenuada está associada à indução de resposta rápida, elevada e imunidade persistente. Se consideradas as dificuldades de armazenamento existentes em um país tropical, a possibilidade de reversão da atenuação e o despreparo dos vacinadores entendem-se que as citadas vantagens deste tipo de vacina não são obtidas, pois quando conservada inadequadamente, resulta em uma concentração viral bem inferior à esperada, visto a termolabilidade do vírus atenuado (VAN KAMPEN, 1999).

O advento das vacinas em cultura de tecido celular replicadas em linhagens de células específicas, levou ao uso generalizado de vacinação antirrábica em todo o mundo, tanto em seres humanos como em animais. Estas vacinas têm demonstrado serem altamente antigênicas, seguras e econômicas com a duração da imunidade por períodos de um a três anos, dependendo da espécie em que a vacina foi utilizada (VAN KAMPEN, 1999).

As vacinas inativadas, embora não apresentem as vantagens das atenuadas, no que se refere à rapidez e durabilidade da resposta imune, tem como fatores importantes a inocuidade e termoestabilidade. Todas contem adjuvantes, como Hidróxido de Alumínio e saponinas, o que faz com que a resposta imunológica seja equiparável às vacinas atenuadas, quando conservadas em condições ideais (KOTAIT, 2009).

Pelo exposto, a Comissão Especial de Raiva dos Herbívoros e Quirópteros, ligados ao Programa de Controle da Raiva do Estado de São 
Paulo, tem recomendado o uso da vacina inativada em todo o Estado (KOTAIT, 2009).

Atualmente, apenas os estados das regiões Norte, Nordeste e parte do Centro-Oeste utilizam principalmente a vacina atenuada e os estados das regiões Sudeste, Sul e parte do Centro-Oeste, a vacina inativada (KOTAIT, 2009).

No Brasil, a instrução Normativa $n^{0}$. 5, de $1^{0}$ de março de 2002, preconiza que a vacinação dos herbívoros seja realizada com vacina contendo vírus inativado, na dosagem de $2 \mathrm{~mL}$ por animal, independentemente da idade, sendo aplicada por via subcutânea ou intramuscular. A vacinação compulsória é recomendada quando da ocorrência dos focos da doença e deve ser adotada preferencialmente em bovídeos e eqüídeos com idade igual ou superior a três meses. Porém, em animais com idade inferior a três meses, poderá ser orientada caso a caso, de acordo com avaliação técnica de um médico veterinário. Animais primovacinados deverão ser revacinados 30 dias após a primeira vacinação. É importante ressaltar que os animais nascidos após a vacinação do rebanho deverão ser vacinados quando atingirem a idade de três meses (BRASIL, 2009).

Falhas vacinais podem ocorrer com freqüência em herbívoros, em decorrência do armazenamento inadequado das vacinas, principalmente as vacinas contendo vírus atenuado (ESDALL, 1969; SUREAU \& ARELLANO, 1971), da via de administração errônea, do estado fisiológico do animal e da idade no momento da primo vacinação (PASTORET et al., 1985), da excessiva carga viral à qual os animais são submetidos (SUREAU \& ARELLANO, 1971) ou ainda pela infecção com variantes do vírus rábico (HIROSE \& VILLEGAS, 1996).

$\mathrm{Na}$ raiva não existe predisposição de raça, sexo ou idade, mas uma prevalência maior da doença pode ser observada em animais jovens (LANGOHR et al., 2003). A ocorrência de numerosos casos em bezerros abaixo de um ano de idade pode estar relacionado principalmente ao estado imunitário dessa categoria animal, uma vez que nessa fase ocorre o declíneo 
da imunidade colostral e os animais ainda não foram vacinados contra raiva, ou quando o foram, na maioria das vezes, não receberam o reforço vacinal, e, em animais recentemente vacinados, que, provavelmente, estavam incubando a doença (LEMOS et al., 2001; MORI et al., 2004).

Estudos para avaliação dos níveis de Ac em bovinos vacinados contra raiva têm sido realizados por diferentes pesquisadores na América do Sul e no Brasil (ARNOLD et al., 1973; ALBAS et al., 1998; OLIVEIRA et al., 2000; ALBAS et al. 2004; ALBAS et al., 2006) em condições experimentais. Nestes trabalhos foram avaliados diferentes períodos pós-vacinais, porém são escassas as publicações relativas ao calendário ideal para o inicio da vacinação antirrábica em bezerros, e pouco se conhece quanto à interferência de Ac colostrais na vacinação nestes animais (CHRISTOPHER et al., 2008).

Em estudo realizado por LIMA et al. (2005), nos 25 casos de raiva bovina diagnosticados no Hospital Veterinário da Universidade Federal de Campina Grande, Paraíba, no período de janeiro de 2002 a agosto de 2004, foi observada uma maior prevalência em animais jovens, com menos de dois anos de idade. Os autores justificaram esse fato em função de menor imunidade desses animais por não terem sido revacinados após 30 dias da primeira vacinação, realizada aos três e quatro meses de idade. A mesma situação foi observada no Mato Grosso do Sul onde também se observou uma maior prevalência em animais jovens (LANGOHR et al., 2003; MORI et al.,2004; LEMOS 2005).

A presença de AcSN em bovinos vacinados contra a raiva é um bom indicador da eficácia da vacina utilizada (ATANASIU, 1973).

ALBAS et al., (2004) Avaliaram a resposta imune humoral induzida por dez lotes de diferentes vacinas antirrábicas em 139 bovinos primovacinados em Presidente Prudente-SP. Os resultados mostraram diferenças importantes quanto à capacidade de diferentes tipos de vacinas de induzirem títulos de Ac antirrábicos. Das dez vacinas antirrábica testadas, três delas apresentaram percentuais de 52,9, 73,3 e 80 de animais não reagentes, demonstrando que 
estes animais poderiam estar expostos a infecção pelo vírus em decorrência de falhas vacinais.

Alguns pesquisadores também relataram resultados semelhantes, confirmando que a resposta imune induzida por apenas uma dose de vacina, não induz altos títulos de Ac (SILVA et al., 2000; UMEHARA et al., 2002; QUEIROZ DA SILVA et al., 2003; PIZA et al., 2002). No entanto, quando se faz uso de doses de reforço, os títulos aferidos se tornam bastante superiores (ALBAS et al., 1998; OLIVEIRA et al., 2000).

É importante considerar que na imunoprofilaxia da raiva podem ser observados insucessos, mesmo quando da utilização de vacinas de comprovada eficácia ou em tratamentos antirrábicos instituídos logo após a agressão (WIKTOR, 1982).

No que se refere ao período de imunidade e eficácia da vacina antirrábica, BAUMGARTEN et al., (1976) em um acompanhamento vacinal em bovinos no México durante um período de três anos, relataram 100\% de efetividade nos animais vacinados com a vacina antirrábica inativada, produzida em cultivo de tecidos.

Em um estudo com 35 bovinos, ALBAS et al., (1998) relataram que o reforço vacinal induziu a uma maior permanência dos AcSN. Os autores observaram que dos 21 animais que receberam uma dose de reforço 30 dias após a primo vacinação, quatro mantiveram títulos de AcSN maior ou igual a 0,5UI/mL após 360 dias, contrariamente ao grupo que não recebeu o reforço, onde apenas um animal apresentou título igual a 0,5UI/mL, 270 dias após.

Em 2006, ALBAS et al., seguindo esta mesma linha de pesquisa, compararam em três grupos de bovinos ( $A, B$ e $C$ ) os níveis de AcSN induzidos por vacina inativada contra raiva usando três protocolos alternativos de imunização. O grupo A recebeu uma única dose de vacina, o grupo B uma dose com reforço após 30 dias e o grupo C uma dose com reforço após 180 dias demonstrando que o título de Ac do grupo $C$ foi superior e também se mantiveram mais elevados por um período mais longo quando comparado com os outros dois grupos. 
SILVA et al., (2000) no Estado de São Paulo, avaliaram a resposta de Ac em bovinos vacinados com duas doses de vacina inativada (PV) e com uma dose de vacina atenuada (ERA), e não observaram diferença significativa entre os títulos de Ac nos animais soropositivos. Entretanto, os títulos de Ac dos animais vacinados com uma única dose de vacina atenuada diminuíram a partir dos 150 dias, ao contrário dos animais vacinados com duas doses de vacina inativada nos quais os títulos mantiveram-se inalterados até os 180 dias após a revacinação.

QUEIROZ DA SILVA et al., (2003) avaliaram os títulos de Ac antirrábicos em 100 bovinos de diferentes propriedades da região de Araçatuba-SP, vacinados em condições de campo pelos proprietários ou encarregados do rebanho. Foram utilizadas três diferentes vacinas comerciais, sendo dois grupos (A e B) com dois tipos de vacina inativada e um grupo (C) com vacina de vírus vivo modificado. Os animais foram avaliados durante 12 meses, nos quais se observou queda do título de Ac em 45\% dos animais vacinados com vacina atenuada e 10\% nos vacinados com a inativada, enfatizando a importância da utilização das vacinas inativadas contra raiva, de acordo com a recomendação oficial, devendo-se realizar o reforço dos animais primo vacinados e revacinar anualmente ou semestralmente de acordo com as características epidemiológicas da região.

Comparativamente com a imunidade ativa descrita acima, a imunidade passiva transferidas através do colostro aos bezerros após o nascimento, tem duração limitada, tendo sido verificado que ela é evidênciavel por um período relativamente curto, ao passo que a imunidade ativamente induzida pela vacinação é em muitos casos mais duradoura. Os ungulados recém-nascidos apresentam essa capacidade de produzir Ac pouco desenvolvida, sendo a sua proteção inicial conseguida pela transferência passiva de imunoglobulinas (Ig) da mãe para o recém-nascido (PORTER, 1972). A via através a qual os Ac maternos alcançam o feto é determinada pela estrutura da placenta. A placenta dos ruminantes é sindesmocorial, ou seja, o epitélio coriônico está em contato direto com os tecidos uterinos. Esse tipo de placenta impossibilita totalmente a passagem transplacentária das moléculas de lg e os recém-nascidos dessa 
espécie são, portanto, dependentes dos Ac recebidos através do colostro e do nível da imunidade sistêmica das mães (CHAMPPUIS, 1998; TIZARD, 2004; ELIZONDO-SALAZAR \& HEINRICHIS, 2008).

Apesar de todos os componentes para o desenvolvimento imune dos bezerros recém nascidos estarem presentes logo após o nascimento, estes são poucos funcionais até que atinjam pelo menos de duas a quatro semanas de vida, se desenvolvendo de forma lenta e gradativa até a maturidade do sistema imune (CHASE et al., 2008; CHRISTOPHER et al., 2008; CORTESE, 2009).

A imediata exposição a agentes infecciosos, ao nascimento, implica que os animais neonatos possuam um mecanismo de defesa apropriado. A imunização passiva, através da absorção de lg presentes no colostro, consequentemente, é considerada como o processo natural mais significativo para conferir uma proteção imunitária eficaz, nas fases iniciais da vida do bezerro (ROBISON et al., 1988; TIZARD, 2004; ELIZONDO-SALAZAR \& HEINRICHIS, 2008).

Durante o seu desenvolvimento, os bezerros recém-nascidos estão sujeitos a diversos efeitos imunomoduladores. Além disso, as vacas também produzem estrogênio e cortisol antes e durante o parto, que tem efeitos imunossupressores, como parte do processo de parturição (CORTESE, 2009). Os bezerros também produzem altos níveis de cortisol no momento do nascimento devido ao "stress" fetal; estes níveis permanecem elevados durante a primeira semana de vida contribuindo no processo de absorção das imunoglobulinas pelo trato gastrintestinal (CHRISTOPHER et al., 2008; CORTESE, 2009).

O colostro tem em sua composição todos os fatores necessários para a sobrevivência do neonato, dentre os quais as Imunoglobulinas (Ig), como os componentes mais importantes, pois garantem a imunidade do animal no período pós-natal (CHAMPPUIS, 1998; TIZARD, 2004; ELIZONDO-SALAZAR \& HEINRICHIS, 2008). Em animais domésticos, o colostro é rico em IgG e IgA, possuindo também $\operatorname{lgM}$ e IgE. A IgG é a imunoglobulina com maior concentração no plasma, compreendendo de 65 a $80 \%$ do total de Ig. A IgM 
corresponde aproximadamente 5 a 10\% de todas Ig presentes na circulação sanguínea (OLSEN \& KRAKOWKA, 1979; GORMAN \& HALLIWELL, 1989). Nos ruminantes, a $\operatorname{lgG}_{1}$ é a classe imunológica predominante, tanto no leite como no colostro (TIZARD, 2004).

Sendo assim, o sucesso da transferência de imunidade passiva através do colostro para os bezerros recém-nascido está, sobretudo, dependente de três fatores: qualidade do colostro, quantidade ingerida e o tempo da ingestão, pois a transferência de lg da corrente sanguínea da mãe para a glândula mamária ocorre principalmente próxima ao parto e geralmente diminui após o nascimento do bezerro (BESSER \& GAY, 1994; MOREIN et al., 2002).

Conclui-se, portanto, que a sobrevivência de bezerros está intimamente vinculada a uma adequada transferência de imunidade passiva por meio do colostro, pois quanto mais elevados os níveis de lg no soro, melhor será a defesa contra agentes infecciosos pelo menos durante o período da $2^{\mathrm{a}}$ à $4^{\mathrm{a}}$ semanas de vida (CHRISTOPHER et al., 2008; MOREIN et al., 2002). Bezerros que ingerem o colostro logo após o nascimento têm grande concentração de lg no soro, enquanto que os bezerros privados do colostro apresentam apenas vestígios durante os três primeiros dias de vida (CHRISTOPHER et al., 2008).

No que se refere aos animais de produção em geral, deve-se destacar que existe uma grande variabilidade na persistência dos Ac maternos. Um dos fatores importantes desta persistência, é o titulo no soro de suas respectivas mães (CHAMPPUIS, 1998; TIZARD, 2004; WEAVER et al., 2000). Por outro lado, estes altos níveis de Ac passivos podem também interferir na resposta imune frente aos desafios vacinais nestes animais, impedindo uma resposta adequada na imunidade ativa (FULTON et al., 2004).

Este problema tem sido demonstrado com vários patógenos, incluindo 0 Vírus respiratório sincicial (BRSV), herpesvírus bovino-1 (BHV-1) e Pasteurella haemolítica. A maioria dos Ac maternos tem uma meia vida de 16 a 28 dias, e o período de inicio das vacinações pode variar de três semanas a oito meses dependendo do antígeno utilizado (CHRISTOPHER et al., 2008). 
Estudo realizado por DONOVAN et al., em 2007, mostrou que bezerros ao receberam colostro fresco contendo células sanguíneas materna responderam ao estímulo com o vírus da diarréia viral bovina (BVDV), 24 horas após o nascimento. Estes estudos fornecem evidencia de que células vivas presentes no colostro materno podem estimular e talvez melhorar a resposta imune de bezerros se expostos a estímulos imunológicos, como vacinação ou infecção.

Nos bovinos, é essencial que os recém-nascidos mamem o colostro até as 24 horas pós-nascimento, porque a concentração das enzimas proteolíticas nos intestinos é muito baixa nas primeiras horas após o nascimento e desta forma, as imunoglobulinas obtidas através da ingestão do colostro alcançam o intestino delgado onde são absorvidas atingindo as células epiteliais por pinocitose, passando completamente para dentro dos capilares intestinais alcançando o sistema circulatório resultando em absorção maciça de lg maternas (CHAMPPUIS, 1998).

Em bezerros, os níveis de IgG alcançam os valores mínimos por volta dos 60 dias de idade, em contraste com as variações das frações IgM e IgA, que diminuem mais rapidamente, alcançando as menores concentrações em torno de 21 dias de idade (OLSEN \& KRAKOWKA, 1979; PERINO et al., 1995).

Pode, porém, existir falha de uma transferência de Ac colostral adequada devido a alguns fatores como: produção de colostro insuficiente ou de má qualidade, volume do colostro ingerido, a concentração de lgG no colostro, idade da vaca na primeira gestação e o peso do bezerro ao nascimento (CHASE et al., 2008, ELIZONDO-SALAZAR \& HEINRICHIS, 2008).

$\mathrm{Na}$ vacinação antirrábica de animais jovens, assim como em qualquer outra vacina, a presença de Ac colostrais pode inibir o estabelecimento da imunidade ativa (PRECAUSTA et al., 1982; TIZARD, 2004). Isso pode ser decorrente em parte de um feedback negativo, através do qual a conjugação dos Ac específicos com os receptores de fragmento cristalizável de imunoglobulina das células $B$, bloqueia a atividade do receptor da célula $B$ e consequentemente inibe a produção adicional de mais Ac da mesma 
especificidade, impedindo dessa forma, sucesso na vacinação em animais jovens, pois os Ac maternos mascaram epítopos dos agentes vacinais, impedindo seu reconhecimento pelas células $B$, logo, a resposta imune só se desenvolve quando os ac maternos caem abaixo do limiar crítico. Esse período refratário pode durar meses, dependendo da quantidade de Ac transferidos para o neonato e da meia vida da Ig (TIZARD, 2004).

BERNARDI e ITO (2000) avaliaram a transferência e a interferência da imunidade materna aos seus descendentes após a vacinação antirrábica em hamsters utilizando fêmeas vacinadas e não vacinadas e vacinando seus descendentes na idade de sete, 14, 21 e 30 dias de vida. Trinta dias após, os filhotes foram desafiados com a inoculação do vírus rábico CVS pela via intracerebral. Percentuais de mortalidade de 97.0, 76.9, 60.9 e 24.0 foram observados em filhotes vacinados aos sete, 14, 21 e 30 dias respectivamente, nascidos de mães vacinadas. Por outro lado, nos filhotes de mães não vacinadas estes percentuais foram de 51.4, 28.6, 8.7 e 0.0, constatando assim que a resposta imunológica à vacinação, de filhotes nascidos de mães vacinadas, foi menor quando comparada com a observada nos filhotes de mães não vacinadas sugerindo a interferência dos Ac colostrais frente à vacinação.

O estudo da competência imunológica dos animais jovens é importante para entender e planejar esquemas de vacinação que aumentem a resistência do rebanho às doenças infecciosas (INGRAM \& SMITH, 1965; PASTORET et al., 1985; AGHOMO, 1990).

SILVA et al. (2008) monitoraram a imunidade passiva em bezerros alimentados com colostro de vacas imunizadas e não imunizadas com vacina contra rotavírus e constataram que a imunização materna não protegeu efetivamente os bezerros das infecções naturais por estes agentes, pois, apesar de aumentar os títulos séricos de Ac antirrotavírus nos animais vacinados, não foi capaz de impedir a ocorrência da rotavirose nos bezerros alimentados com colostro das vacas imunizadas, porém, a imunidade ativa foi 
mais tardia e menos intensa, indicando que os anticorpos maternos poderiam estar suprimindo a resposta imune.

Em estudo realizado por BUNN (1988), a interferência na vacinação de bezerros com a vacina constituída por amostra viral SAD também foi atribuída a Ac colostrais. O autor observou, entretanto, que o título de Ac mensurado nos bezerros mais jovens foi extremamente menor e não correlacionado com o título das mães após o nascimento. Desta forma considerou que, uma vez que bezerros de mães não vacinadas não haviam sido incluídos nesse estudo, existia a possibilidade de ter ocorrido uma resposta imune inadequada em animais jovens, decorrente da resposta imunológica insuficiente muito mais que da interferência dos Ac colostrais.

Pesquisa realizada na Bolívia por ARNOLD et al., (1973), avaliaram a possibilidade da interferência de Ac colostrais maternos contra raiva em bezerros, filhos de mães revacinadas seis meses antes do parto com vacina ERA. Os bezerros foram vacinados com uma única dose da mesma vacina aos quatro, cinco, seis e sete meses de idade. A média de títulos de AcSN entre os quatro grupos foi de 5.0, 7.7, 15.8 e $31.9 \mathrm{UI} / \mathrm{mL}$ respectivamente, sendo detectados Ac maternos até o $6^{\circ}$ mês de idade. Os resultados indicaram interferência sobre a resposta da vacinação em bezerros jovens recomendando a revacinação aos 12 meses de idade.

Em pesquisas anteriores com vacas primovacinadas e não submetidas ao reforço vacinal, observou-se interferência de Ac colostrais em bezerros filhos de mães vacinadas, vacinados aos dois e quatro meses de idade, evidenciado por menor número de animais que soroconverteram 15 dias após a vacinação antirrábica. Após o reforço vacinal, no entanto, os bezerros responderam à vacina de forma similar. Adicionalmente, neste experimento, os autores observaram ausência de soro conversão em nove $(35,7 \%)$ de 30 vacas, caracterizando possíveis falhas vacinais sugerindo a necessidade do reforço vacinal (GERONUTTI, 2002).

Tem-se preconizado a primo vacinação aos três meses de idade com reforço vacinal após 30 dias na profilaxia da raiva. Até essa idade, a maioria 
dos bezerros, provenientes de mães vacinadas, têm Ac de origem colostral em níveis satisfatórios para a proteção. Quando os bezerros são filhos de mães não vacinadas, devem ser vacinados logo ao nascer, pois embora não tenham um sistema imunológico tão competente quanto de animais mais velhos, a vacinação precoce vai ativar as células de memória, colaborando com uma futura resposta imunológica (KOTAIT, 2009).

SOULEBOT (1978) refere que, para ser efetiva, é contra indicada a vacinação antes dos quatro meses de idade em animais filhos de mães vacinadas. De acordo com o mesmo autor, de forma ideal, os bezerros devem atingir a idade de nove meses antes de serem vacinados. Quando vacinados entre quatro e seis meses, é aconselhável o reforço vacinal antes de atingirem um ano de idade.

O calendário da administração de muitas vacinas envolve a estimativa do momento em que o nível de Ac maternos é baixo o suficiente para induzir uma resposta imune ativa nos bezerros visando fornecer imunidade para um determinado antígeno vacinal, pois a maioria dos Ac maternos tem um declínio entre 16 a 28 dias após o nascimento (FULTON et al., 2004).

Desta forma, considerando a obrigatoriedade da vacinação e revacinação antirrábica em áreas de ocorrência da doença, assim como, a orientação da vacinação em bezerros a partir de três meses de idade, com permissão de vacinação mais precoce de acordo com a avaliação técnica do médico veterinário responsável $(\mathrm{PNCRH})$ partiu-se da hipótese de que há a possibilidade de interferência na vacinação antirrábica decorrente dos Ac colostrais em bezerros filhos de fêmeas revacinadas, o que reduziria o sucesso dos programas de controle da enfermidade. 


$$
\text { - }
$$


Considerando a necessidade do controle da raiva em herbívoros, fundamentada na vacinação e revacinação dos animais, pretendeu-se neste experimento avaliar a possível interferência de anticorpos colostrais na vacinação antirrábica em bezerros com dois, quatro e seis meses de idade, filhos de mães revacinadas contra a raiva. 


\subsection{SELEÇÃO DOS ANIMAIS}

Os animais utilizados no trabalho pertencem a Fazenda experimental da FMVZ - UNESP - Botucatu, situada à Rodovia Marechal Rondon, município de São Manuel.

\subsection{DELINEAMENTO EXPERIMENTAL}

Foram selecionadas 40 vacas adultas, nelore, que se encontravam no terço final de gestação. Estes animais foram revacinados contra a raiva um ano após a primo vacinação, juntamente com a vacinação de febre aftosa, e mantidas em observação até o nascimento dos bezerros, que mamaram o colostro livremente, sem interferência externa.

Foi colhido sangue das mães 48 horas após o nascimento dos bezerros para avaliação do título de AcSN antirrábicos.

Neste mesmo momento, os bezerros foram divididos em lotes e coletado sangue para avaliação do título de AcSN antirrábicos. Foram constituídos quatro grupos compostos de dez bezerros independentes do sexo, sendo um grupo de bezerros não vacinados, e três grupos que foram vacinados, respectivamente, aos dois, quatro e seis meses de idade e submetidos a reforço vacinal após 30 dias. Os animais foram acompanhados sorológicamente 15 dias após cada vacinação e mensalmente até completarem um ano de idade.

Os resultados foram avaliados comparativamente entre os diferentes grupos. 


\subsubsection{Grupo de vacas revacinadas}

Dia zero: 40 vacas, em terço final de gestação, foram revacinadas por via subcutânea, com vacina inativada ${ }^{*}$ contendo $\geq 1$ UI INH de vírus fixo Pasteur em volume de $2 \mathrm{~mL}$, acrescido de hidróxido de alumínio e saponina qsp como adjuvantes. Após o nascimento, as vacas juntamente com seus bezerros foram divididos em quatro grupos compostos por dez animais.

\subsubsection{Grupos de bezerros:}

- Grupo A: bezerros não vacinados

- Grupo B: bezerros vacinados aos dois meses

- Grupo C: bezerros vacinados aos quatro meses

- Grupo D: bezerros vacinados aos seis meses

\subsection{COLHEITA DE MATERIAL}

\subsubsection{Seleção e colheita de sangue dos animais}

Foram colhidas amostras de sangue de todos os bezerros 48 horas após o nascimento, juntamente com sangue de suas mães. A colheita dos materiais foi realizada após assepsia local com álcool iodado. O sangue foi colhido através de venopunção jugular utilizando-se sistema à vácuo estéril sem anticoagulante (Vacuttainer), retirando-se aproximadamente $10 \mathrm{~mL}$ de sangue por animal. Após retração e retirada do coágulo, cada alíquota de soro foi armazenada em tubos tipo eppendorf®, identificada e conservadas em freezer $\left(-20^{\circ} \mathrm{C}\right)$ até a realização das provas sorológicas.

\footnotetext{
${ }^{1}$ * Alurabiffa Merial
} 


\subsubsection{Soroneutralizacão em cultura celular (SN)}

As provas sorológicas foram realizadas no laboratório de raiva do Centro de Controle de Zoonose, São Paulo-SP. Os soros obtidos dos animais foram descongelados no momento da realização da prova, inativados a $56^{\circ} \mathrm{C}$ por 30 minutos e diluídos a 1:5 com meio Eagle enriquecido e acrescido de antibiótico, sendo realizadas diluições em placas de 96 poços, da seguinte forma: $20 \mu$ le soro teste e $80 \mu \mathrm{l}$ de meio no primeiro poço e $50 \mu \mathrm{l}$ de meio nos três poços seguintes. O soro e o meio de cultura do primeiro poço, após a diluição foram homogeneizados com micropipetas e $50 \mu \mathrm{l}$ transferidos aos poços subseqüentes da coluna vertical. A cada poço foi adicionado $50 \mu$ do vírus PV pré titulado e as placas incubadas por $1 \mathrm{~h}$ a $37^{\circ} \mathrm{C}$ em estufa de $\mathrm{CO}_{2}$, após o que foi adicionado, a cada poço, $50 \mu$ de suspensão de células BHK $\left(73^{\mathrm{a}}\right.$ passagem). As placas foram mantidas em estufa de $\mathrm{CO}_{2}$ a $37^{\circ} \mathrm{C}$ por $24 \mathrm{hs}$, para realização da leitura em microscópio de imunofluorescência (SMITH et al., 1973; FAVORETTO et al., 1993).

Utilizou-se soro antirrábico padrão previamente titulado em unidades internacionais (UI) como referencia, sendo considerados $0,5 \mathrm{UI} / \mathrm{mL}$ como título protetor (ALBAS et al., 1998).

\subsubsection{Imunofluorescência direta (IFD)}

Para a realização da IFD, foi realizada a aspiração dos sobrenadantes dos poços das placas de cultivo celular com micropipeta de oito canais, sendo a camada celular fixada com solução de acetona $80 \%$ por dez minutos à $-20^{\circ} \mathrm{C}$. Após a retirada da acetona, as placas fixadas foram secas em estufa a $37^{\circ} \mathrm{C}$, adicionadas a cada poço $50 \mu \mathrm{L}$ de conjugado antirrábico e mantidas em estufa a $37^{\circ} \mathrm{C}$ por 1 hora. Em seguida, foi realizada uma lavagem com solução salina tamponada, seguida de uma lavagem com água destilada. Após as placas estarem secas, acrescentou-se uma gota de glicerina tamponada $\mathrm{pH}$ 8,5 por poço e a leitura foi realizada com o auxílio de um microscópio de imunofluorescência em objetiva 16X. O título final dos soros foi considerado tomando como base a última diluição em que se observou $50 \%$ de neutralização viral e calculada através de regra de três frente ao soro padrão. 


\subsection{ANÁLISE ESTATÍSTICA}

Foram realizadas as seguintes análises estatísticas:

Análise exploratória e comparação entre bezerros não vacinados e vacinados em diferentes idades em relação a variação em percentual dos títulos de AcSN dos bezerros 48 horas após o nascimento em relação aos títulos de AcSN maternos, pelo teste de Kruskal-Wallis para amostras independentes.

Comparação entre as idades na $1^{\text {a }}$ vacinação em relação ao título sorológico por meio do teste de Kruskal-Wallis seguido do teste de Dunn para comparações múltiplas após aplicação do teste de Shapiro-Wilk para verificação do ajuste da distribuição normal ao desafio investigado (SIEGEL \& CASTELLAN, 1988; CORDER \& FOREMAN, 2009).

Comparação entre as idades na primeira vacinação em relação ao percentual de bezerros desprotegidos (título abaixo de $0,5 \mathrm{UI} / \mathrm{mL}$ ) por meio do teste de Qui-quadrado ou pelo teste exato de Fisher.

Comparação entre as idades na primeira vacinação em relação ao percentual de bezerros soro convertidos (aumento de título de no mínimo quatro vezes entre dois momentos de observação) pelo teste de Quí-quadrado ou pelo teste exato de Fisher.

Resumo descritivo dos títulos de AcSN antirrábicos dos bezerros não vacinados e dos vacinados aos dois, quatro e seis meses de idade ao longo do período estudado nos diferentes momentos representados em mediana e quartis.

Para exploração dos dados e análises estatísticas foram utilizados os programas SPSS v15.0 e GraphPad Prism v4.

As diferenças estimadas foram consideradas estatisticamente significativas se $p<0,05$ em qualquer teste estatístico aplicado. 
Foram avaliados os títulos de AcSN das vacas e dos bezerros 48 horas pós parto e mensalmente nos grupos de bezerros vacinados ou não vacinados, a partir de 15 dias após a vacinação (PV1) e revacinação (PV2) nos grupos de bezerros vacinados nas diferentes faixas etárias. Os resultados detalhados estão apresentados no Anexo 1.

Quando considerados os títulos de AcSN dos diferentes lotes de bezerros comparativamente ao título de AcSN materno 48 horas pós nascimento observou-se que dos bezerros não vacinados e vacinados aos dois, quatro e seis meses de idade 10\%, 11\%, 30\% e 20\% respectivamente, apresentaram titulo de AcSN superiores aos de suas respectivas mães. Títulos de AcSN inferiores ao materno foram observados nos bezerros não vacinados, vacinados aos dois e seis meses 10\%,11\%, e 10\% enquanto que os bezerros vacinados com quatro meses, 0\% apresentaram títulos de AcSN inferiores ao materno. AcSN iguais ao materno foram determinados em 80\%, 77\%, 70\% e $70 \%$ dos bezerros não vacinados, vacinados aos dois, quatro e seis meses de idade respectivamente. Os resultados demonstraram haver uma relação direta entre o título materno e o adquirido via colostro pelos bezerros (Figura 1).

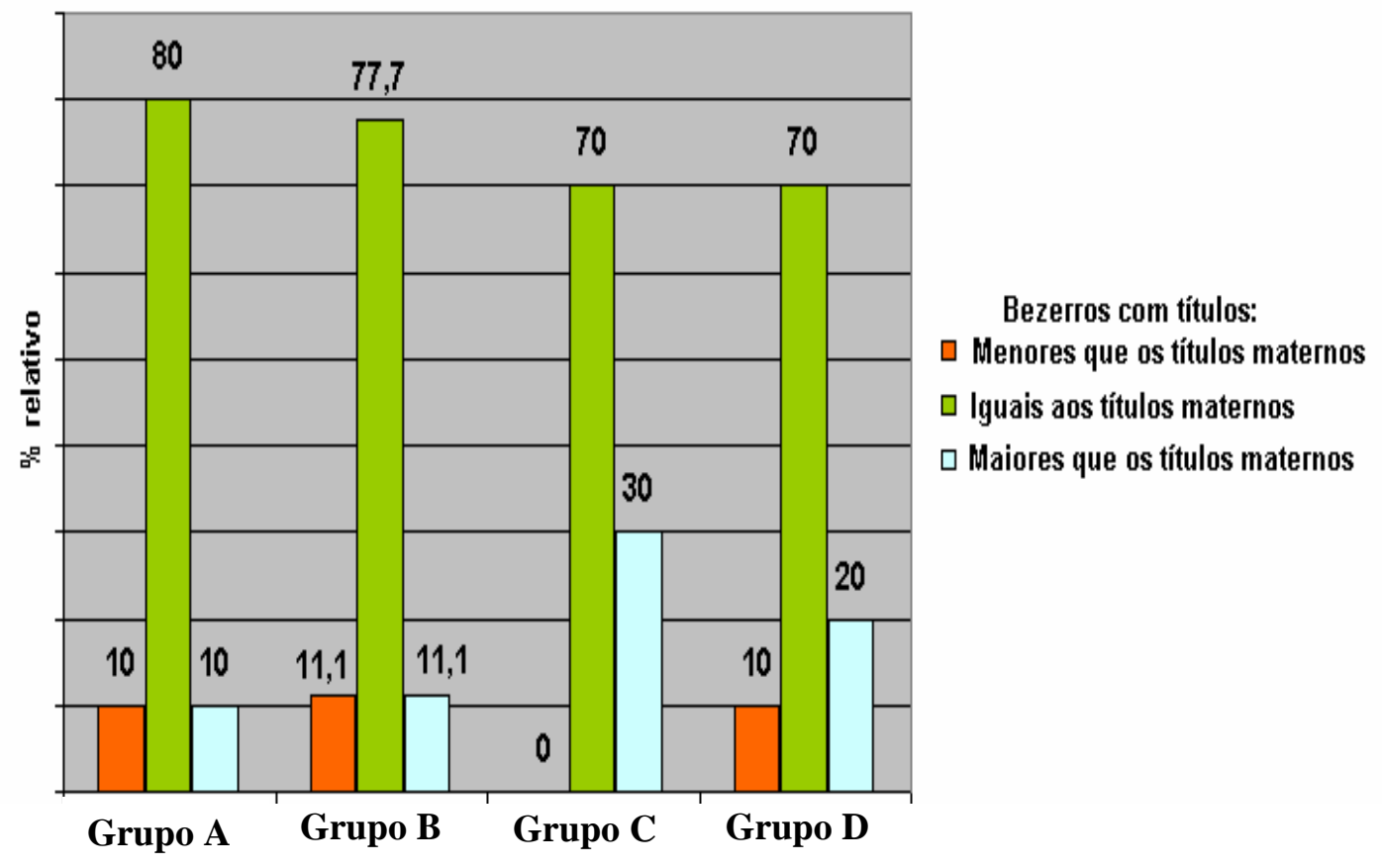

Figura 1 - Distribuição da variação (em \%) dos títulos AcSN dos bezerros 48 horas pós nascimento em relação aos títulos AcSN maternos, segundo idade na vacinação. 
Outro fator de importância para a constituição dos grupos e interferência de anticorpos maternos na vacinação antirrábica dos bezerros nas várias faixas etárias seria a diferença de títulos de anticorpos nos grupos de bezerros constituídos. Desta forma a avaliação estatística demonstrou que com base no teste de Kruskal-Wallis para amostras independentes, que não houve diferença significativa entre os grupos formados em relação à transferência de anticorpos colostrais (Tabela 1).

Tabela 1 - Resumo descritivo da variação em percentual dos títulos dos bezerros 48horas após o nascimento e o título materno segundo idade na vacinação

\begin{tabular}{|c|c|c|c|c|c|}
\hline & \multicolumn{4}{|c|}{ Idade na vacinação } & \multirow[b]{2}{*}{$P^{(*)}$} \\
\hline & $\begin{array}{c}\text { Grupa A } \\
\text { Não } \\
\text { vacinados } \\
\end{array}$ & $\begin{array}{c}\text { Grupo B } \\
\text { vacinados } \\
\text { aos } 2 \text { meses } \\
\end{array}$ & $\begin{array}{c}\text { Grupo C } \\
\text { vacinados } \\
\text { aos } 4 \text { meses } \\
\end{array}$ & $\begin{array}{c}\text { Grupo } D \\
\text { vacinados } \\
\text { aos } 6 \text { meses } \\
\end{array}$ & \\
\hline Média \pm Desvio-padrão & $0,80 \pm 13,5$ & $8,3 \pm 35,2$ & $9,7 \pm 15,6$ & $5,8 \pm 20,8$ & \multirow{2}{*}{0,576} \\
\hline Mediana (Quartís) & $0,0(0,0 ; 0,0)$ & $0,0(0,0 ; 0,0)$ & $0,0(0,0 ; 32,5)$ & $0,0(0,0 ; 8,1)$ & \\
\hline
\end{tabular}

$\left(^{\star}\right)$ Teste de Kruskal-Wallis para amostras independentes.

Foram avaliadas as respostas à vacinação e revacinação dos diferentes grupos nos vários momentos (Tabela 2).

Diferença significativa foi observada entre os grupos quanto ao título de AcSN do dia da vacina comparativamente às 48 horas do nascimento; 15 dias pós revacinação ( PV2) frente ao dia da revacinação e frente ao dia da vacinação; e 12 meses pós nascimento frente o dia da vacina.

Os resultados estatísticos significativos estão apresentados na tabela 2 e figura 2. 
Tabela 2 - Comparação entre as idades nas vacinações em relação ao título sorológico.dos diferentes grupos nos vários momentos

\begin{tabular}{|c|c|c|c|c|}
\hline \multirow{2}{*}{ Variação (\%) } & \multicolumn{3}{|c|}{ Idade na vacinação } & \multirow{2}{*}{$p^{(*)}$} \\
\hline & 2 meses $(n=9)$ & 4 meses $(n=10)$ & 6 meses $(n=10)$ & \\
\hline Nascimento $x$ Vacina & $0,0(-50,5 ; 0,0) \mathbf{a}$ & $-78,3(-87,7 ;-43,6) \mathbf{b}$ & $-62,3(-84,7 ;-46,7) \mathbf{b}$ & $0,008^{(1 a)}$ \\
\hline Vacina x PV1 (15 dias pós vacina) & $-23,1(-43,0 ; 0,0) \mathbf{a}$ & $-17,5(-38,8 ; 7,5) \mathbf{a}$ & $30,0(-20,9 ; 116,3) \mathbf{a}$ & 0,196 \\
\hline $\begin{array}{l}\text { PV1 (15 dias pós vacina) x } \\
\text { Revacina }\end{array}$ & $0,0(-46,0 ; 0,0) \mathbf{a}$ & $53,8(-29,8 ; 151,9) \mathbf{a b}$ & $155,8(-5,8 ; 715,4) \mathbf{b}$ & $0,034^{(1 b)}$ \\
\hline $\begin{array}{l}\text { Vacina } \times \text { Revacina (30 dias pós } \\
\text { vacina) }\end{array}$ & $-24,5(-71,3 ;-11,5) \mathbf{a}$ & $0,0(-37,8 ; 182,5) \mathbf{a b}$ & $132,5(24,4 ; 334,6) \mathbf{b}$ & $0,002^{(1 c)}$ \\
\hline $\begin{array}{l}\text { Revacina x PV2 (15 dias pós } \\
\text { revacina) }\end{array}$ & $32,5(0,0 ; 318,9) \mathbf{a}$ & $307,7(-0,95 ; 430,0) \mathbf{a}$ & $16,2(0,0 ; 132,5) \mathbf{a}$ & 0,257 \\
\hline $\begin{array}{l}\text { PV2 } \times 1 \text { mês pós revacina ( } 30 \text { dias } \\
\text { pós PV2) }\end{array}$ & $0,0(-56,1 ; 0,0) \mathbf{a}$ & $-50,5(-75,5 ; 0,0) \mathbf{a}$ & $-12,3(-24,5 ; 0,0) \mathbf{a}$ & 0,398 \\
\hline $\begin{array}{l}\text { Revacina x } 1 \text { mês pós revacina ( } 30 \\
\text { dias pós revacina) }\end{array}$ & $32,5(0,0 ; 100,0) \mathbf{a}$ & $30,0(0,0 ; 151,9) \mathbf{a}$ & $0,0(-6,1 ; 37,1) \mathbf{a}$ & 0,201 \\
\hline $\begin{array}{l}1 \text { mês pós revacina } \times 12 \text { meses pós } \\
\text { nascimento }\end{array}$ & $0,0(-55,2 ; 15,0) \mathbf{a}$ & $77,3(-29,7 ; 207,7) \mathbf{a}$ & $16,2(0,0 ; 32,5) \mathbf{a}$ & 0,170 \\
\hline Vacina $\times 12$ meses pós nascimento & $-24,5(-58,8 ; 0,0) \mathbf{a}$ & $203,8(-6,1 ; 451,3) \mathbf{b}$ & $165,0(131,9 ; 715,4) \mathbf{b}$ & $0,002^{(1 d)}$ \\
\hline $\begin{array}{l}\text { Revacina } \times 12 \text { meses pós } \\
\text { nascimento }\end{array}$ & $0,0(-29,8 ; 66,3) \mathbf{a}$ & $186,3(22,5 ; 301,9) \mathbf{a}$ & $16,3(0,0 ; 116,3) \mathbf{a}$ & 0,115 \\
\hline
\end{tabular}

$\left.{ }^{\star}{ }^{\star}\right)$ Teste de Kruskal-Wallis para amostras independentes. Resumo descritivo em mediana e quartís.

PV1 $=15$ dias pós vacinação $\quad$ PV2 = 15 dias pós revacinação 


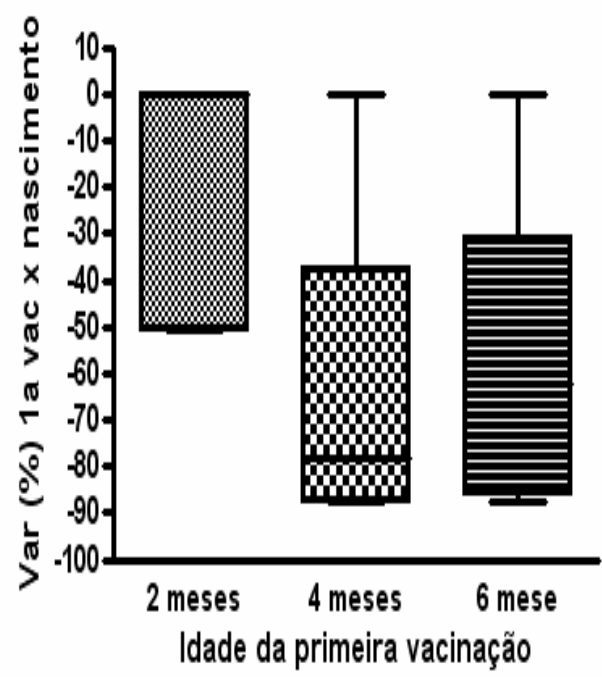

(1a)

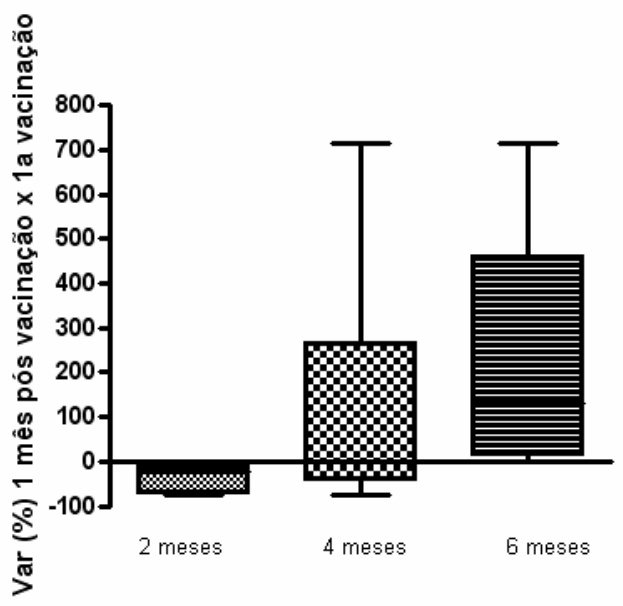

(1c)

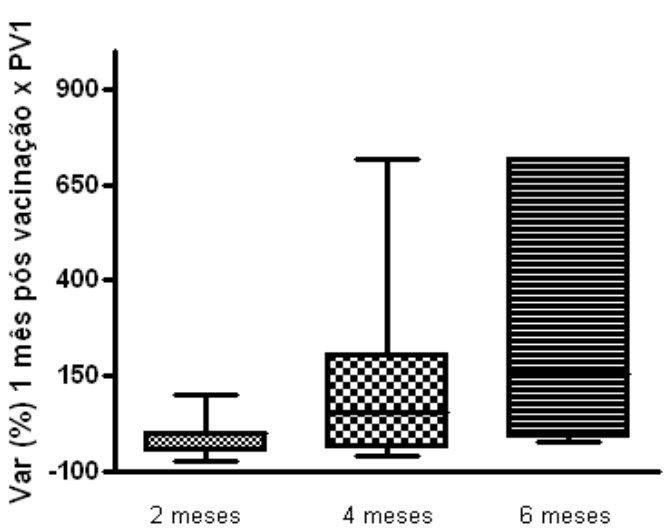

(1b)

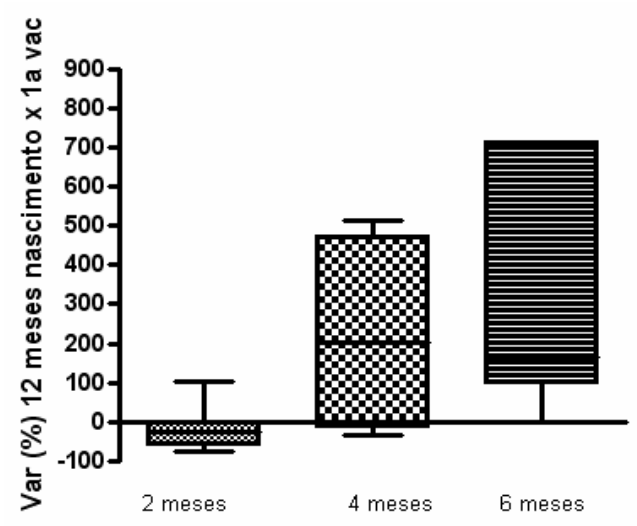

(1d)

Figura 2 - Distribuição das variações percentuais dos títulos de AcSN: (1a) Da $1^{a}$ vacinação em relação ao titulo de Ac 48 horas pós nascimento, (1b) 30 dias após a vacinação $x$ título de Ac 15 dias pós PV1, (1c) 30 dias pós vacina $x$ título de Ac no dia da primo vacinação e (1d) 12 meses pós nascimento em relação ao título de Ac na primo vacinação. 
A figura 2 apresenta a distribuição das variações percentuais dos títulos de AcSN nos grupos e momentos em que se observou diferença significativa a vacinação ou revacinação.

O gráfico (1a) representa a distribuição da variação em \% do título de AcSN no dia da primeira vacinação em relação ao título de Ac 48 horas pós nascimento. Os títulos de AcSN nos bezerros vacinados aos dois meses de idade não apresentou variação frente ao título apresentado 48 horas após o nascimento, pois cerca de $50 \%$ dos bezerros apresentou valores abaixo de $0 \%$, resultado que diferiu estatisticamente dos outros grupos de bezerros vacinados aos quatro e seis meses de idade, que apresentaram queda de $78 \%$ e $62 \%$ nos título de AcSN maternos do nascimento a primo vacinação.

No gráfico (1b) observamos os títulos de AcSN 30 dias após a primo vacinação comparados com os títulos apresentados 15 dias após a mesma. Verificamos que os valores diferiram significativamente entre os grupos de bezerros vacinados aos dois meses e seis meses de idade, não se observando diferença estatística no grupo vacinado com quatro meses de idade. Este resultado foi evidenciado por títulos de AcSN similares nos dois momentos nos bezerros vacinados aos dois meses, enquanto que observou-se aumento expressivo de títulos de AcSN no grupo vacinados aos seis meses. O grupo vacinado aos quatro meses, embora tenha apresentado aumento, este se situou intermediário entre os dois grupos anteriores.

O gráfico (1c) representa a variação em \% do título de AcSN um mês após a primo vacinação. De forma similar aos resultados anteriores, o grupo vacinado aos dois meses apresentou diferença significativa do grupo vacinado aos seis meses quando comparados os títulos de AcSN 30 dias após a primo vacinação frente aos títulos de $\operatorname{AcSN}$ no dia da vacinação. No grupo de bezerros vacinado com dois meses de idade, cerca de 50\% dos animais apresentaram queda de 24,5\% nos títulos de AcSN no momento da revacinação frente aos títulos de AcSN mensurados na aplicação da primeira vacina, diferenciando significativamente do grupo vacinado aos seis meses, 
que não apresentou queda nos títulos de AcSN entre a primo vacinação e revacinação.

O gráfico (1d) representa os títulos de AcSN 12 meses após o nascimento frente a primo vacinação. O grupo de bezerros vacinados aos dois meses diferiu significativamente dos demais grupos vacinados aos quatro e seis meses. Aos dois meses, cerca de 50\% apresentou queda de $24 \%$ do título de Ac, enquanto que os grupos vacinados aos quatro meses e seis meses não apresentaram diferença estatística entre eles tendo sido observado aumento dos títulos de Ac frente ao dia da vacinação.

O percentual de desproteção nos vários grupos e vários momentos está apresentado na tabela 3. Aos 15 dias pós primo vacinação, 33,3\% dos bezerros vacinados aos dois meses encontravam-se desprotegidos enquanto que nos vacinados com quatro meses e seis meses observou-se, respectivamente, $70 \%$ e $60 \%$ de desproteção. Aos 15 dias após a revacinação (booster), dos bezerros vacinados aos dois meses, 11,1\% encontravam-se desprotegidos em relação dos vacinados aos quatro meses e seis meses de idade, nos quais todos se apresentaram protegidos, não sendo verificada diferença significativa entre os grupos.

Aos 12 meses após o nascimento, 44,4\% dos bezerros vacinados pela primeira vez aos dois meses encontravam-se desprotegidos enquanto que o percentual observado de bezerros desprotegidos vacinados aos quatro meses foi de $20 \%$ e todos os bezerros vacinados aos seis meses estavam protegidos aos 12 meses. Com base no teste exato de Fisher, houve evidência para concluir sobre uma diferença significativa, do ponto de vista estatístico, entre as vacinas realizadas aos dois e seis meses de idade $(p=0,032)$, porém, não houve diferença significativa entre as vacinas realizadas entre dois e quatro meses de idade $(p=0,349)$ e entre as vacinas realizadas entre quatro e seis meses de idade $(p=0,473)$. 
Tabela 3 - Comparação entre as idades na primeira vacinação em relação ao percentual de bezerros desprotegidos (título abaixo de 0,5 Ul/mL)

\begin{tabular}{ccccc}
\hline \multirow{2}{*}{ Momento } & \multicolumn{4}{c}{ Idade na vacinação } \\
\cline { 2 - 5 } & Não vacinados $(\boldsymbol{n}=\mathbf{1 0})$ & $\mathbf{2}$ meses $(\boldsymbol{n}=\mathbf{9})$ & $\mathbf{4}$ meses $(\boldsymbol{n}=\mathbf{1 0})$ & $\mathbf{6}$ meses $(\boldsymbol{n}=\mathbf{1 0})$ \\
\hline Nascimento & 0,0 & 0,0 & 0,0 & 0,0 \\
$1^{\circ}$ mês & 0,0 & 0,0 & 0,0 & 0,0 \\
$2^{\circ}$ mês & 20,0 & 11,1 & 0,0 & 10,0 \\
$3^{\circ}$ mês & 40,0 & 44,4 & 50,0 & 30,0 \\
$4^{\circ}$ mês & 40,0 & 33,3 & 70,0 & 60,0 \\
$5^{\circ}$ mês & 60,0 & 44,4 & 70,0 & 60,0 \\
$6^{\circ}$ mês & 100,0 & 66,7 & 40,0 & 80,0 \\
$7^{\circ}$ mês & 100,0 & 77,8 & 70,0 & 20,0 \\
$8^{\circ}$ mês & 90,0 & 44,4 & 30,0 & 10,0 \\
$9^{\circ}$ mês & 40,0 & 22,2 & 20,0 & 0,0 \\
$10^{\circ}$ mês & 40,0 & 0,0 & 20,0 & 0,0 \\
$11^{\circ}$ mês & 20,0 & 33,3 & 0,0 & 0,0 \\
$12^{\circ}$ mês & 10,0 & $44,4 \mathbf{a}$ & 20,0 ab & 0,0 b \\
\hline PV1 & & $33,3 \mathbf{a}$ & 70,0 a & 60,0 a \\
PV2 & $11,1 \mathbf{a}$ & $0,0 \mathbf{a}$ & $0,0 \mathbf{a}$ \\
\hline
\end{tabular}

A tabela 4 demonstra o percentual de soro conversão nos diferentes grupos pós vacinação. Observou-se que aos 15 dias pós vacinação, nenhum dos grupos apresentou bezerros soro convertidos, enquanto que, 15 dias pós revacinação 33,3\% dos bezerros vacinados aos dois meses apresentaram soro conversão enquanto que $50 \%$ dos bezerros vacinados aos quatro meses soro converteram; não se observou soroconversão em nenhum dos bezerros vacinados aos seis meses ( $p<0,05$ - Teste exato de Fisher). 
Tabela 4 - Comparação entre as idades na primeira vacinação em relação ao percentual de bezerros soro convertidos (aumento de título de, no mínimo, quatro vezes entre dois momentos de observação)

\begin{tabular}{ccccc}
\hline Momento & \multicolumn{4}{c}{ Idade na vacinação } \\
\cline { 2 - 5 } & $\begin{array}{c}\text { Não vacinados } \\
(\boldsymbol{n}=\mathbf{1 0})\end{array}$ & $\begin{array}{c}\mathbf{2} \text { meses } \\
(\boldsymbol{n}=\mathbf{9})\end{array}$ & $\begin{array}{c}\mathbf{4} \text { meses } \\
(\boldsymbol{n}=\mathbf{1 0})\end{array}$ & $\begin{array}{c}\mathbf{6} \text { meses } \\
(\boldsymbol{n}=\mathbf{1 0})\end{array}$ \\
\hline $1^{\circ}$ Mês $\times$ nasc & 0,0 & 0,0 & 0,0 & 0,0 \\
$2^{\circ}$ mês $\times 1^{\circ}$ mês & 0,0 & 0,0 & 0,0 & 0,0 \\
$3^{\circ}$ mês $\times 2^{\circ}$ mês & 0,0 & 0,0 & 0,0 & 0,0 \\
$4^{\circ}$ mês $\times 3^{\circ}$ mês & 0,0 & 0,0 & 0,0 & 0,0 \\
$5^{\circ}$ mês $\times 4^{\circ}$ mês & 0,0 & 0,0 & 20,0 & 0,0 \\
$6^{\circ}$ mês $\times 5^{\circ}$ mês & 0,0 & 0,0 & 20,0 & 10,0 \\
$7^{\circ}$ mês $\times 6^{\circ}$ mês & 0,0 & 11,1 & 0,0 & 20,0 \\
$8^{\circ}$ mês $\times 7^{\circ}$ mês & 10,0 & 33,3 & 20,0 & 10,0 \\
$9^{\circ}$ mês $\times 8^{\circ}$ mês & 50,0 & 33,3 & 10,0 & 10,0 \\
$10^{\circ}$ mês $\times 9^{\circ}$ mês & 20,0 & 22,2 & 0,0 & 0,0 \\
$11^{\circ}$ mês $\times 10^{\circ}$ mês & 10,0 & 0,0 & 20,0 & 0,0 \\
$12^{\circ}$ mês $\times 11^{\circ}$ mês & 0,0 & 0,0 & 0,0 & 0,0 \\
\hline PV1 $\times$ vacina & & 0,0 a & 0,0 a & 0,0 a \\
\hline PV2 $\times$ revacina & & 33,3 ab & 50,0 a & 0,0 b \\
\hline
\end{tabular}

$\mathrm{Na}$ tabela 5 observamos que não houve diferença significativa na mediana dos títulos de AcSN entre os todos os grupos, no período correspondente ao nascimento até os dois meses de idade. Títulos de AcSN menores que $0,5 \mathrm{UI} / \mathrm{mL}$ foram observados nos grupos de bezerros não vacinados a partir do $5^{\circ}$ até $08^{\circ}$ mês. Nos vacinados aos dois meses, observou-se do $6^{\circ}$ ao $8^{\circ}$ mês; no grupo vacinado aos quatro meses títulos não protetores foram evidenciados do $4^{\circ}$ ao $7^{\circ}$ mês e do grupo correspondente a vacinação aos seis meses de idade, esta situação foi evidenciada do $4^{\circ}$ ao $6^{\circ}$ mês. Aumento nos títulos de AcSN ocorreu em todos os grupos a partir do $9^{\circ}$ mês 
Tabela 5 - Resumo descritivo dos títulos de AcSN antirrábicos dos bezerros não vacinados e dos vacinados aos dois, quatro e seis meses de idade ao longo do período estudado nos diferentes momentos (valores representados em mediana e quartis).

\begin{tabular}{|c|c|c|c|c|c|c|c|c|c|c|c|c|}
\hline \multirow{2}{*}{$\begin{array}{l}\text { Momento } \\
\text { de } \\
\text { observação }\end{array}$} & \multicolumn{3}{|c|}{ Não vacinados } & \multicolumn{3}{|c|}{2 meses } & \multicolumn{3}{|c|}{4 meses } & \multicolumn{3}{|c|}{6 meses } \\
\hline & Q1 & Mediana & $3 Q$ & Q1 & Mediana & $3 Q$ & Q1 & Mediana & $3 Q$ & Q1 & Mediana & $3 Q$ \\
\hline $\begin{array}{c}48 \text { horas } \\
\text { pós } \\
\text { nascimento }\end{array}$ & 1,06 & 1,06 & 1,06 & 1,06 & 1,06 & 1,06 & 1,06 & 1,06 & 1,06 & 1,06 & 1,06 & 1,06 \\
\hline 1 mês & 1,06 & 1,06 & 1,06 & 1,06 & 1,06 & 1,06 & 1,06 & 1,06 & 1,06 & 0,87 & 1,06 & 1,06 \\
\hline 2 mês & 0,80 & 0,80 & 1,06 & 0,52 & 1,06 & 1,06 & 0,80 & 1,06 & 1,06 & 0,66 & 1,06 & 1,06 \\
\hline 3 mês & 0,40 & 0,68 & 1,00 & 0,20 & 0,80 & 0,80 & 0,40 & 0,60 & 0,80 & 0,43 & 0,67 & 1,00 \\
\hline 4 mês & 0,30 & 0,53 & 0,73 & 0,40 & 1,06 & 1,06 & 0,15 & 0,23 & 0,50 & 0,20 & 0,23 & 0,73 \\
\hline 5 mês & 0,13 & 0,26 & 0,73 & 0,40 & 0,53 & 0,80 & 0,22 & 0,26 & 0,50 & 0,20 & 0,26 & 0,80 \\
\hline 6 mês & 0,13 & 0,13 & 0,18 & 0,26 & 0,40 & 0,80 & 0,30 & 0,52 & 0,93 & 0,15 & 0,40 & 0,40 \\
\hline 7 mês & 0,13 & 0,13 & 0,18 & 0,13 & 0,20 & 0,26 & 0,20 & 0,26 & 0,90 & 0,60 & 0,93 & 1,06 \\
\hline 8 mês & 0,13 & 0,13 & 0,13 & 0,13 & 0,53 & 1,06 & 0,43 & 0,80 & 1,00 & 0,80 & 0,93 & 1,06 \\
\hline 9 mês & 0,26 & 0,80 & 1,06 & 0,53 & 1,06 & 1,06 & 0,53 & 1,06 & 1,06 & 1,06 & 1,06 & 1,06 \\
\hline 10 mês & 0,26 & 1,06 & 1,06 & 1,06 & 1,06 & 1,06 & 0,60 & 1,06 & 1,06 & 1,06 & 1,06 & 1,06 \\
\hline 11 mês & 0,80 & 1,06 & 1,06 & 0,26 & 1,06 & 1,06 & 1,06 & 1,06 & 1,06 & 1,06 & 1,06 & 1,06 \\
\hline 12 mês & 0,66 & 1,06 & 1,06 & 0,26 & 0,80 & 1,06 & 0,80 & 0,80 & 1,06 & 1,06 & 1,06 & 1,06 \\
\hline
\end{tabular}


6. Discussão 
Considerando a necessidade do controle da raiva em herbívoros, fundamentada na vacinação e revacinação dos animais, pretendeu-se neste experimento avaliar a possível interferência de anticorpos colostrais na vacinação antirrábica em bezerros com dois, quatro e seis meses de idade, filhos de mães revacinadas contra a raiva.

Um dos aspectos avaliados neste trabalho foi o titulo de AcSN nas vacas revacinadas. Os resultados obtidos no presente estudo mostraram a presença do título de AcSN maiores que 0,5UI/mL, 48 horas após do nascimento de seus bezerros, em todas as vacas revacinadas no terço final de gestação. Resultado diferente ao nosso foram obtidos por GERONUTTI (2002) que utilizou em seu projeto de pesquisa fêmeas bovina da raça Nelore primovacinadas contra a raiva, também em fase final de gestação, e observou ausência de titulo, após o nascimento de seus bezerros, em nove (35,7\%) dos 30 animais avaliados. A autora justifica possível falha vacinal devido a uma única dose de vacina, em concordância com trabalhos realizados por ALBAS et al., (1998) ao concluírem que uma dose de reforço induziu a uma maior permanência dos AcSN nos animais primovacinados. Estes autores observaram que dos 21 animais que receberam uma dose de reforço 30 dias após a primo vacinação, quatro mantiveram títulos de AcSN maior ou igual a 0,5UI/mL após 360 dias, contrariamente ao grupo que não recebeu o reforço, onde apenas um animal apresentou título igual a 0,5UI/mL, 270 dias após.

Alguns pesquisadores também relataram resultados semelhantes, uma vez que a resposta imune induzida por apenas uma dose de vacina, não apresentou títulos elevados de Ac (SILVA et al., 2000, UMEHARA et al., 2002; QUEIROZ DA SILVA et al., 2003; PIZA et al., 2002). Porém, quando se fez uso de doses de reforço, os títulos aferidos se tornaram bastante superiores (ALBAS et al., 1998; OLIVEIRA et al., 2000; ALBAS et al., 2006), resultados esses, concordantes com os verificados em nosso trabalho de pesquisa, utilizando vacas revacinadas.

Títulos de AcSN ,superiores ou em níveis similares ao materno, foram observados em seus respectivos bezerros 48 horas após o nascimento e ingestão do colostro, indicando a transferência de Ac colostrais em todos os 
grupos de animais estudados. Estes resultados são discordantes de BUNN (1988) e GERONUTTI (2002), que ao avaliarem a transferência de Ac colostrais em bezerros, observaram que o título dos AcSN antirrábicos mensurados em bezerros filhos de vacas primovacinadas, foi extremamente menor e não correlacionados com o título das mães após o nascimento, reforçando a necessidade e importância da revacinação materna frente à imunidade transferida via colostro aos seus descendentes.

COSTA et al. em 2008, com o objetivo de investigar alguns aspectos relacionados à transferência de imunidade passiva em bezerros de corte das raças Nelore e Limosin manejados extensivamente sob condições naturais, avaliaram o comportamento das proteínas séricas ao longo dos primeiros quatro meses de vida,e observaram que a transferência de Ac foi eficiente em ambas as raças, porém, as concentrações mais elevadas de lg ao término do primeiro dia de vida, declinaram até os valores mínimos aos 60 dias de vida.

Títulos de AcSN a partir do nascimento até 60 dias de vida foram similares em todos os grupos de bezerros estudados em nosso trabalho, caracterizando meia vida dos Ac circulantes adquiridos passivamente pelo colostro, aspecto esse concordante com COSTA et al. (2008) e reforçado por GERONUTTI (2002) que verificou que os títulos de AcSN a partir de 30 dias até 60 dias de idade foram similares em todos os lotes de bezerros estudados, independente do estado vacinal materno, caracterizando meia vida dos anticorpos adquiridos passivamente (TIZARD, 2004).

Resultados semelhantes foram, também, observados por MAHMOOD et al., em 2007, que determinaram o status imunológico de bezerros filhos de mães vacinadas durante a gestação, contra Pasteurella multocida e consideraram que a duração da imunidade materna durou até 45 dias após o nascimento esgotando aos 60 dias de vida.

Em nosso trabalho, nos bezerros não vacinados filhos de mães revacinadas contra a raiva bovina, a média dos títulos de Ac colostrais $\geq a$ $0,5 \mathrm{Ul} / \mathrm{mL}$ foi observado até o $4^{\circ}$ mês de vida, com queda gradual até o $8^{\circ}$ mês quando foram observados os menores títulos de AcSN. Estes resultados 
diferem dos encontrados por HUBNER et al., em 1996 que determinou em seu estudo, a concentração e a duração da imunidade colostral contra 0 herpesvírus bovino tipo 1 (BHV-1), através da análise de amostras de soro de bezerras da raça Holandesa coletadas às seis, 12, e 24 horas após 0 nascimento, semanalmente dos 7 dias até 63 dias de idade, e mensalmente até 180 dias, onde estimaram que as bezerras a partir dos 180 dias de vida não apresentavam sorologia positiva, tendo como efeito da imunidade passiva para BHV-1 através do teste de soroneutralização (SN), o que pode ser justificados pela diferença do agente etiológico estudado.

Diferem também, dos verificados por ARNOLD et al, em 1973, que observaram Ac maternos contra a raiva bovina em 40 bezerros até o $6^{\circ}$ mês de vida.

As discrepâncias de resultados são citadas por PAULETTI et al. (2002) e COSTA et al. (2008) como conseqüente a fator racial e a diferentes sistemas de criação desses animais, pois os bezerros leiteiros manejados intensivamente estão normalmente sujeitos ao contato freqüente e mais precoce com agentes infecciosos, o que pode causar consumo dos Ac circulantes. Admite-se comumente que os bezerros estejam mais susceptíveis a contrair infecção nessa faixa etária crítica marcada pelo intervalo de tempo em que se mantêm as menores concentrações séricas de gamaglobulinas, período entre o término do processo de degradação das lg passivamente transferidas e a produção ativa pelo sistema imunológico competente (RADOSTITS et al. 2002).

Nos bezerros vacinados aos dois meses de idade, títulos de AcSN em níveis similares ao apresentado 48 horas após o nascimento foi observado no dia da vacinação, resultado que diferiu estatisticamente dos outros grupos de bezerros vacinados aos quatro e seis meses de idade, que apresentaram queda de $78 \%$ e $62 \%$ nos título de Ac maternos do momento do nascimento até a primo vacinação.

Diferença significativa nos títulos de AcSN, foi observada somente 30 dias pós primo vacinação e 30 dias após a revacinação nos grupos de bezerros 
vacinados aos dois meses e nos grupos vacinados aos seis meses de idade, estando o grupo com quatro meses de idade de forma intermediária entre os demais, indicando que após a primo vacinação, tanto os bezerros vacinados aos dois meses quanto os vacinados aos quatro meses, apresentaram resposta similar, caracterizando neste momento uma baixa resposta vacinal nestes grupos. No entanto, após a revacinação, a resposta vacinal se comportou de forma similar com aumento nos títulos de Ac entre os grupos estudados.

A capacidade de resposta a vacinação mesmo em presença de títulos de Ac colostrais foi observada por ZIMMERMAN et al., em 2006 ao avaliarem a proteção contra o vírus da diarréia viral bovina tipo1 (BVDV) em três grupos de bezerros que ingeriram colostro contendo Ac contra BVDV (grupo 1) e colostro sem Ac anti-BVDV (grupo 2 e 3). Os animais dos grupos 1 e 2 foram vacinados contra BVDV, enquanto que e o grupo 3 foi vacinado com placebo, ambos com cinco semanas de vida, e desafiados três meses e meio após a vacinação com a cepa BVDV-2. Os bezerros do grupo 3 que foram vacinados com placebo desenvolveram a doença grave enquanto os bezerros dos grupos 1 e 2 desenvolveram apenas um quadro leve ou sem sinais clínico da doença, concluindo nos resultados que a vacina de vírus vivo atenuado induziu a uma resposta imune protetora nos bezerros, mesmo quando as concentrações plasmáticas de Ac maternos eram altas.

A resposta a vacinação em bezerros com dois meses de idade foi similar aos bezerros vacinados em idade mais tardia, observada neste experimento, que se justifica também com base em pesquisas recentes, que têm mostrado que bezerros jovens vacinados frente a imunidade materna são capazes de mostrar provas de imunidade celular, e até mesmo, irá exibir uma memória de resposta de Ac para proteção quando exposto ao mesmo antígeno mais tarde na vida (CHASE et al., 2008). Embora o sistema imunológico seja capaz de conferir diferentes graus de proteção, é esta combinação de imunidade passiva e ativa que em conjunto oferece proteção, muitas vezes em forma de redução da gravidade da doença para o recém nascido (CORTESE, 2009). 
Em nosso trabalho, avaliamos que nos animais vacinados aos dois meses de idade, o título de anticorpos colostrais era bastante elevado sofrendo queda para níveis considerados não protetores somente a partir do $6^{\circ}$ até $07^{\circ}$ mês de vida, em contraste aos encontrados por GERONUTTI (2002), que observou títulos de Ac inferiores a $0,5 \mathrm{Ul} / \mathrm{mL}$ no momento da primo vacinação em bezerros filhos de vacas primovacinadas vacinados aos dois meses de idade.

Os grupos de animais não vacinados, vacinados aos quatro e seis meses apresentaram um decréscimo nos títulos de AcSN considerados protetores a partir do $4^{\circ}$ mês de vida, enquanto que no grupo de bezerros vacinados aos dois meses iniciou-se no $6^{\circ}$ mês, permitindo a esses animais um tempo maior de proteção, fato este de grande importância em áreas endêmicas e epidêmicas da doença. Resultados concordantes com GERONUTTI (2002) que referiu período de desproteção a partir do $6^{\circ}$ mês em bezerros vacinados aos dois meses de idade, filhos de mães primo vacinadas contra a raiva, sendo o período de desproteção inferior ao dos bezerros vacinados aos quatro e seis meses de idade.

Em relação aos resultados acima, devemos levar em consideração aos resultados acima alguns fatores que podem interferir também em relação aos títulos de Ac transferidos passivamente, como estado fisiológico materno no momento da vacinação e após o parto, que de forma direta pode contribuir na qualidade e quantidade do colostro bem como nos níveis de Ac produzidos pela mãe, a quantidade de colostro ingerido pelo bezerro e a capacidade de absorção das imunoglobulinas pelo trato gastrintestinal, fatores estes que de certa forma podem influenciar diretamente nos títulos de Ac passivamente adquiridos pelos bezerros após o nascimento (CHASE et al, 2008).

O grupo de bezerros vacinados aos quatro meses de idade situou-se de forma intermediaria entre o grupo vacinado aos dois meses e seis meses. Estes animais apresentaram um período de desproteção entre o $4^{\circ}$ e $7^{\circ}$ mês de vida, onde os títulos de AcSN apresentaram valores abaixo de 0,5UI/mL. A partir do $7^{\circ}$ mês, os bezerros vacinados aos quatro meses e revacinados após 
30 dias, não apresentaram diferença significativa frente os animais não vacinados e os vacinados aos dois meses, porém, os títulos de AcSN foram inferiores ao dos bezerros vacinados com seis meses de idade. Resultados semelhantes foram observados por GERONUTTI (2002), sugerindo interferência dos Ac colostrais na primo vacinação dos bezerros neste momento, semelhante ao grupo de bezerros vacinados aos dois meses de idade.

Títulos de Ac colostrais superiores a $0,5 \mathrm{UI} / \mathrm{mL}$ foram observados durante os três primeiros meses de vida nos bezerros do grupo $D$, vacinados aos seis meses de idade. A partir do $3^{\circ}$ mês, estes animais apresentaram queda gradual nos títulos de AcSN, ficando desprotegidos até o momento da primo vacinação, quando responderam a vacina com títulos protetores após 30 dias da mesma. Uma vez que o título apresentado após a primo vacinação se encontrava em níveis elevados, não se observou soroconversão após a revacinação, aspecto justificado pela não extinção dos títulos na prova de soroneutralização.

Estes resultados são similares aos observados por GERONUTT (2002) em bezerros vacinados aos seis meses de vida, filhos de mães primo vacinadas e não vacinadas contra a raiva, os quais, após reforço vacinal apresentaram percentual similar de soro conversão com títulos maiores que 0,5Ul/mL, caracterizando ausência de interferência colostral.

No entanto, discordam de ARNOLD et al. (1973), que avaliaram a interferência de Ac colostrais em 40 bezerros filhos de vacas vacinadas seis meses antes do parto. Os títulos dos bezerros demonstraram evidente passagem dos derivados do colostro antes de receberem a primeira dose da vacina antirrábica. Os animais foram vacinados aos quatro, cinco, seis e sete meses de idade, sendo que os títulos de AcSN para a raiva foram maiores nos bezerros vacinados com sete meses de vida. Reforçou ainda os autores que bezerros vacinados antes de completarem seis meses de idade deveriam receber reforço vacinal ao completarem 12 meses, perfil similar ao evidenciado em nosso trabalho. 
Quando avaliamos a soro conversão nos animais estudados, representada pela tabela 4, observamos que 15 dias pós primo vacinação, não houve diferença significativa entre os grupos, pois nenhum bezerro soro converteu, porém 15 dias após a revacinação (booster), 33,3\% dos bezerros vacinados com dois meses e $50 \%$ dos bezerros vacinados aos quatro meses soro converteram, enquanto que nenhum dos bezerros vacinados aos seis meses soro converteu, mas todos os grupos apresentaram títulos de AcSN $\geq a$ 0,5UI/mL em mediana, corraborando com GERONUTTI (2002) onde 15 dias após a revacinação todos os bezerros estudados apresentaram títulos de AcSN antirrábicos superiores a $1 \mathrm{UI} / \mathrm{mL}$.

Em todos os grupos de bezerros vacinados em nosso trabalho de pesquisa, pudemos observar que não houve resposta sorologicamente satisfatória frente a primo vacinação 15 dias após a mesma, porém evidenciouse aumento significativo nos títulos dos AcSN antirrábicos 30 dias após a mesma e 15 dias após a revacinação principalmente no grupo vacinado aos 6 meses de idade. A ausência de títulos sorológicos indicativos de soro conversão neste grupo se justifica pelo titulo de anticorpos em níveis elevados apresentados no momento da revacinação e pela técnica de soroneutralização utilizada, uma vez que não se realiza a extinção dos títulos sorológicos na mesma.

Os títulos de AcSN não mantiveram níveis satisfatórios nos grupos de bezerros vacinados com dois e quatro meses sendo observado uma diminuição nos títulos de AcSN no decorrer da idade, enquanto que nos animais vacinados aos seis meses o titulo de AcSN permaneceu superior aos demais grupos após a revacinação até completarem 12 meses de vida, fato este observado também por ALBAS et al. (2005), que estudaram cinco esquemas vacinais em bovinos com idade média de um ano que haviam sido vacinados contra raiva bovina. $O$ grupo A havia recebido uma única dose de vacina no dia 0, o grupo B seguindo o mesmo esquema com reforço após 30 dias, o Grupo C vacinados no dia zero, com reforço após180 dias, enquanto que o grupo $\mathrm{D}$, além do dia zero, recebeu mais duas doses de reforço, sendo uma no dia 30 e outra no dia 60. Os animais do grupo $\mathrm{E}$ receberam mais duas doses de reforço aplicadas no dia 
30 e 180 dias, após a primeira vacinação. Os autores observaram que o esquema de vacinação do grupo $E$ foi mais eficiente e duradouro sugerindo que a vacinação antirrábica nestes animais seja realizada com três doses, sendo os reforços administrados nos dias 30 e 180 após a primeira vacinação.

Títulos de Ac menores que 0,5UI/mL são considerados baixos, tanto em animais como em seres humanos pela Organização Mundial da Saúde (OMS).

O tempo maior de desproteção foi observado nos bezerros não vacinados os quais apresentaram uma janela imunológica prolongada em relação aos demais grupos iniciando-se do $5^{\circ}$ ao $8^{\circ}$ mês tornando esses animais expostos a doença.

Nos bezerros vacinados com dois meses de idade, a presença de títulos de AcSN não protetores menores que $0,5 \mathrm{UI} / \mathrm{mL}$ foi observada no $6^{\circ}$ e $7^{\circ}$ mês de vida, nos vacinados aos quatro meses este período se situou entre o $4^{\circ}$ e $7^{\circ}$ mês e nos vacinados aos seis meses, entre o $4^{\circ}$ e $6^{\circ}$ mês. Período este inferior ao encontrado por GERONUTTI, em 2002, onde todos os grupos de bezerros filhos de vacas primovacinadas nasceram sem títulos considerados protetores e mantiveram desproteção até $03^{\circ}$ mês, $5^{\circ}$ mês e $6^{\circ}$ mês de idade, respectivamente, para os grupos vacinados aos dois meses, quatro meses e seis meses de idade.

Podemos assim observar que os bezerros filhos de mães revacinadas, quando vacinados aos dois meses de idade, apresentaram um período menor de desproteção contra o vírus da raiva em relação aos demais grupos, propiciando assim, uma imunidade precoce frente ao vírus rábico, aspecto bastante interessante especialmente em áreas endêmicas.

$\mathrm{Na}$ comparação entre as idades da primeira vacinação em relação ao percentual de bezerros desprotegidos (título AcSN menor que 0,5UI/mL), observamos que aos 12 meses após o nascimento, 44,4\% dos bezerros vacinados pela primeira vez aos dois meses encontravam-se desprotegidos enquanto que o percentual observado nos bezerros vacinados aos quatro meses foi de $20 \%$, e nenhum dos vacinados aos seis meses se encontrava desprotegido aos 12 meses de vida. Desta forma, podemos concluir que ao 
atingirem 12 meses de idade, os animais vacinados aos seis meses apresentavam grau de proteção superior até o momento da primo vacinação, quando comparados com os bezerros vacinados com dois meses de idade, enquanto que os vacinados aos quatro meses situaram-se de forma intermediária entre os grupos, indicando interferência dos Ac colostrais e necessidade de revacinação, afirmado anteriormente por (ALBAS et al., 1998; OLIVEIRA et al., 2000; ALBAS et al., 2006).

Ressalta-se neste experimento de forma similar ao observado por GERONUTTI (2002) o aumento nos títulos de AcSN antirrábico a partir do $9^{\circ}$ mês de idade em todos os grupos de bezerros vacinados e não vacinados. Este fato pode estar associado à utilização de outras vacinas aplicadas dentro do manejo rotineiro da propriedade onde foi realizado o estudo, como vacinas para contra Clostridiose e Febre Aftosa, justificando o fato, a resposta vacinal inespecífica devido ao adjuvante destas vacinas, o qual pode induzir a produção de Ac inespecíficos, pois os adjuvantes são substâncias imunopotencializadoras muito importante quando o antígeno possui baixa imunogenicidade além de auxiliar a formação de uma resposta imune de maior intensidade, de maior duração e mais rápida com uma quantidade menor de antígeno, podendo assim diminuir os custos na produção de vacinas (LARGHI \& NEBEL, 1985; RESENDE et al., 2004).

Resposta inespecifica foi também observado por HALDAR et al. (1977), que utilizou o Mycobacterium phlei em camundongos vacinados contra a raiva, e obteve aumento na porcentagem de soro conversão e proteção dos animais contra o vírus rábico.

A necessidade de realizar um plano para vacinação em animais de produção contra determinadas doenças é muito importante e devemos levar principalmente em consideração as necessidades e os riscos de uma determinada região. Muitas vezes, os programas de vacinações podem ser ou não uma grande ameaça à saúde dos bezerros. É preciso analisar cuidadosamente os antígenos que estão sendo utilizados para certificar-se de que eles serão potencialmente capazes de estimular antigenicamente a 
resposta imune. Em segundo lugar, o efeito da imunidade materna e a idade do bezerro devem ser considerados, pois a resposta dos bezerros mais jovens é inferior quando comparadas aos mais bezerros mais velhos. A relação inversa é verdadeira do ponto de vista da proteção conferida pela imunidade materna, pois quanto mais jovem for o bezerro, melhor é a proteção devido a altos níveis de Ac maternos, e os bezerros mais velhos são mais susceptíveis as doenças devido ao declínio dos Ac, fatores estes de relevante importância (WOOLUMS, 2007).

A criação de bovinos tem participação significativa na economia pecuária nacional. Para alcançar adequados índices de produção, esta criação depende de fatores genéticos, alimentares e relacionados ao manejo sanitário, que permitirão que o bovino possa desenvolver seu potencial máximo de produção e de dar conseqüente retorno econômico ao criador. Os bezerros ocupam posição especial na cadeia de produção, devendo-se ressaltar que o manejo neonatal a que forem submetidos terá reflexos sobre sua vida produtiva, influenciando significativamente seu futuro desempenho como fonte de carne ou leite.

As vacinações de bezerros recém-nascidos não podem fornecer a amplitude de proteção contra a infecção que o colostro pode proporcionar, no entanto, se a falha de transferência passiva ocorrer, a vacinação pode ajudar os bezerros a resistirem a determinadas doenças (DONOVAN et al., 2007); necessita-se, portanto, de um acompanhamento atento e freqüente a esses animais em relação às vacinações para que possam estar protegidos contra determinadas doenças antes de atingirem a idade adulta.

Os resultados deste experimento demonstraram uma resposta à vacinação antirrábica embora não idêntica, mas similar em todos os grupos de bezerros vacinados com dois, quatro e seis meses de vida filhos de mães revacinadas, devendo ser obrigatoriamente realizado o booster, e revacinação anual.

Estes mesmos resultados foram observados por GERONUTTI (2002) em vacas primovacinadas. A evidência de uma resposta vacinal similar em 
bezerros filhos de mães primovacinadas, vacinados e revacinados, demonstra a viabilidade da antecipação de protocolos vacinais independentemente do estado vacinal materno quando necessário.

Esta possibilidade se reveste de maior importância epidemiológica, particularmente em regiões epidêmicas para a raiva, onde a precocidade na idade de vacinação evitaria a morte de um grande numero de animais, reduzindo desta forma os prejuízos econômicos, além dos riscos oferecidos a saúde do homem, decorrente desta grave enfermidade. 
A revacinação contra a raiva, durante a gestação, induz títulos de AcSN em níveis protetores que são transferidos de forma diretamente proporcional aos bezerros via colostro.

Anticorpos colostrais, com títulos protetores contra a raiva, se mantêm por um período variável de três a quatro meses nos bezerros filhos de mães revacinadas durante a gestação.

Interferência dos anticorpos colostrais na vacinação contra a raiva foi evidenciada na primo vacinação dos bezerros vacinados aos dois meses e em menor intensidade nos vacinados aos quatro meses.

A revacinação contra a raiva induz resposta de AcSN de forma similar nos grupos vacinados aos dois, quatro e seis meses, neutralizando a interferência evidenciada na primo vacinação.

A vacinação contra a raiva aos dois meses de idade possibilita um menor período de desproteção comparativamente aos demais grupos, induzindo imunidade precoce frente ao vírus da raiva.

O reforço vacinal anual é fundamental para a manutenção dos títulos de Ac SN nos animais.

A vacinação antirrábica pode ser indicada em bezerros a partir de dois meses de idade condicionada a obrigatoriedade do reforço vacinal independentemente do estado vacinal materno. 
8. Referências 
ACHKAR, S.M.; SINHORINI, I.L.; RIBEIRO, O.G.; CARRIERI, M.L.; CERETTA, R.S.; CONSALES, C. A. Immunopathology of rabies infection in mice selected for high or low acute inflammatory reaction. J. Venom. Anim. Toxins incl. Trop. Dis., v.1, p.39-55, 2007.

AGHOMO, H.O.; ODUYE, O.O.; RUPPRECHT, C.E. The serological response of young dogs to the Flury LEP strain of rabies virus vaccine. Vet. Res. Commun., v.14, n.5, p.415-425, 1990.

AGRO REDE. O que é raiva bovina? Notícias Agro Rede Especial, Londrina, 10 set. 2007. Disponível em:http://www.agroredenoticias.com.br/>. Acesso em: 10 out. 2009.

ALBAS, A.; PARDO, P.E.; GOMES, A.A.B.; BERNARDI, F.; ITO F.H. Effect of a booster-dose of rabies vaccine on the duration of virus neutralizing antibody titers in bovines. Rev. Soc. Bras. Med. Trop., v.4, p.367-371, 1998.

ALBAS, A.; FONTOLAN, O.L.; PARDO, P.E.; BREMER NETO, H. Resposta imune humoral em bovinos vacinados contra a raiva em Presidente Prudente, SP, Brasil. Arq. Inst. Biol., v.71, supl., p.1-749, 2004.

ALBAS, A.; PARDO, P.E.; BREMER NETO, H.; GALLINA, N.M.F.; MOURÃO FUCHES, R.M.; SARTORI, A. Vacinação antirrábica em bovinos: comparação de cinco esquemas vacinais. Arq. Inst. Biol., v.72, p153-159, 2005.

ALBAS, A.; FONTOLAN, O.L.; PARDO, P.E.; BREMER NETO, H.; SARTORI, A. Interval between first dose and booster affected antibody production in cattle vaccinated against rabies. J. Venom. Anim. Toxins incl. Trop. Dis., v.12, n.3, p.476-486, 2006.

ARNOLD, R.M.; SALVATIERRA, J. Immunity against paralytic rabies in cattle following vaccination with ERA vaccine under ranch conditions in Bolivia. Part of maternal antibody on the success of vaccination of calves of different ages. Trop. Anim. Health Prod., v.5, p.6-11, 1973. 
ATANASIU, P. Quantitative assay and potency test of antirabies serum and immunoglobulin. WHO Monogr. Serv., v.23, n.314, p. 314-318, 1973.

BARROS, C.S.L.; DRIEMEIER, D.; DUTRA, I.S.; LEMOS, R.A.A. Doenças do sistema nervoso de bovinos no Brasil. São Paulo: AGNS, 2006. p.21-28.

BAUMGARTEN, E.H.; RUIZ, J.M.; SOTA, C.A.; VELA, J.C.; BAÑOS, B.L.; ROMERO, H.P. Evaluacion de una vacuna comercial antirrábica inactivada para bovinos, producida en cultivo de tejidos (Alurabiffa). Tec. Pecu. Mex., n.30, p.57-63, 1976.

BELOTTO, A.; LEANES, L.F.; SCHNEIDER, M.C.; TAMAYO, H.; CORREA, E. Overview of rabies in the Americas. Virus Res., n.111, p.5-12, 2005.

BERNARDI, F.; ITO, F.H. Maternal antibody passively transferred interferes with rabies vaccination in hamsters. Comp. Immun. Microbiol. Infect. Dis., v.23, p.185-195, 2000.

BESSER, T.E.; GAY, C.C. The importance of colostrums to the health of neonatal calf. Vet. Clin. North Am. Food Anim. Pract., v. 10, n.1 p. 107-117, 1994.

BRASIL. Ministério da Saúde. Fundação Nacional da Saúde. Morcegos em áreas urbanas e rurais: manual de manejo e controle. Brasília: Gráfica e Editora Brasil, 1996. 117p.

BRASIL. Ministério da Saúde. Secretaria de Vigilância em Saúde. Guia de vigilância epidemiológica. 6.ed. Brasília: Ministério da Saúde, 2006. 806p.

BRASIL. Ministério da Agricultura. Programa Nacional de Controle da Raiva dos Herbívoros. Manual técnico. Brasília, 2009. Disponível em: <http://www. agricultura.gov.br>. Acesso em: 10 ago. 2009. 
BUNN, T.O. Vaccines and vaccination of domestic animals. In: CAMPBELL, J.B.; CHARLTON, K.M. Rabies. Boston: Kluwer, 1988. v.2, p.321-333.

CALLAN, J.R.; METRE, D.C.V. Viral diseases of the ruminant nervous system. Vet. Clin. Food Anim., v.20, p.327-362, 2004.

CARINI, A. Sur une grande epizòotie de rage. Ann. Inst. Pasteur, v.25, p.843846, 1911.

CARNIELI, P.; FAHL, W.O.; CASTILHO, J.G.; OLIVEIRA, R.N.; MACEDO, C. I.; DURYMANOVA, E.; JORGE, R.S.P.; MORATO, R.G.; SPÍNDOLA, R.O.; MACHADO, L.M.; SÁ, J.E.U.; CARRIERI, M.L.; KOTAIT, I. Characterization of rabies vírus isolated from canids and identification of the main wild canid host in Northeastern Brazil. Vírus Res. v.131, p. 33-46, 2008.

CHAMPPUIS, G. Neonatal immunity and immunization in early age: lessons from veterinary medicine. Vaccine, v.16, n.13, p.1468-1472, 1998.

CHASE, C.C.L.; HURLEY, D.J.; REBER, A.J. Neonatal immune development in the calf and its impact on vaccine response. Vet. Clin. Food Anim., v.24, p.87104, 2008.

CHRISTOPHER, C.L.; CHASE, C.L.; HURLEY, D.J.; REBER, A.J. Neonatal Immune Development in the Calf and Its Impact on Vaccine Response. Vet. Clin. Food. Anim., v. 24, p. 87-104, 2008.

CORRÊA, S.H.R.; PASSOS, E.C. Wild animals and public health. In: FOWLER, M.E. Biology, medicine and surgery of South American wild animals. Ames: lowa State University Press, 2001. p.493-499.

CORDER, G.W.; FOREMAN, D.I. Noparametric Statistics for Non-Statistics: a step-by-step. New Jersey: John Wiley \& Sons, 2009. 
CORTESE, V.S. Neonatal Immunology. Vet. Clin. Food Anim., v. 25, p. 221227, 2009.

COSTA, M.C.; FLAIBAN, K.K.M.C.; CONEGLIAN, M.M.; FEITOSA, F.L.F.; BALARIN, M.R.S.; LISBÔA, J.A.N. Transferência de imunidade passiva em bezerros das raças Nelore e Limosin e proteinograma sérico nos primeiros quatro meses de vida. Pesq. Vet. Bras., v. 28, n. 9, 2008.

DONOVAN, D.C.; REBER, A.J.; GABBARD, J.D.; ACEVES-AVILA, M.; GALLAND, K.L.; HOLBERT, K.A.; ELY, L.O.; HURLEY, D.J. Effest of maternal cells tranferred with colostrum on cellular responses to pathogens in neonatal calves. Am. J. Vet. Res., v. 68, n. 7, p. 778-782, 2007.

ELIZONDO-SALAZAR, J.A.; HEINRICHS, A.J. Review: Heat Treating Bovine Colostrum. Profes. Anim. Sci.. v. 24, p 530-538, 2008.

ESDALL, G. Aspectos técnicos de los programas de vacunación. Bol. Of. Sanit. Panam., v.66, p.305-408, 1969.

FAUQUET, C.M.; MAYO, M.A.; MANILOFF, J.; DESSELBERGER, U.; BALL, L.A. Virus taxonomy: the eighth report of the Internacional Committee on Taxonomy of Virases. New York: Academia Press, 2004. 1162p.

FAVORETTO, S.R.; CARRIERI, M.L.; TINO, M.S.; ZANETTI, C.R.; PEREIRA, O.A.C. Simplified fluorescent inhibition microtest for the titration of rabies neutralizing antibodies. Rev. Inst. Med. Trop. São Paulo, v.35, n.2, p.171-175, 1993.

FAVORETTO, S.R.; MATTOS, C.C.; MORAIS, N.B.; CARRIERI, M.L.; ROLIM, B.N.; SILVA, L.M.; RUPPRECHT, C.E.; DURIGON, E.L.; MATTOS, C.A. Rabies Virus Maintained by Dogs in Humans and Terrestrial Wildlife, Ceará State, Brazil. Emerg. Infect. Dis., v. 12, n. 12 p. 1978-1981, 2006.

FERNANDES, C.G. Raiva. In: RIET-CORREA, F.; SCHILD, A.L.; MÉNDEZ, M.C.; LEMOAS, R.A.A. Doenças de ruminantes e eqüinos. São Paulo: Varela, 2001. v.1, p.149-162. 
FULTON, R.W.; BRIGGS, R.E.; PAYTON, M.E.; CONFIRA, A.W.; SALIK, J.T.; RIDPATH, J.F.; BURGE, L.J.; DUFF, G.C. Maternally derived humoral immunity to bovine viral diarrhea virus (BVDV) 1a, BVDV 1b, BVDV 2, bovine herpesvirus-1, parainfluenza-3 virus bovine respiratory syncytial virus, Mannheimia haemolytica and Pasteurella multocida in beef calves, antibody decline by half-life studies and effect on response to vaccination. Vaccine, v.22, p.643-649, 2004.

GERONUTTI, L.M. Vacinação anti-rábica em bezerros: resposta imune humoral e interferência de anticorpos colostrais. 2002. 83f. Dissertação (Mestrado) - Faculdade de Medicina Veterinária, Universidade Estadual Paulista, Botucatu.

GORMAN, N. T.; HALLIWELL, R. E. Veterinary clinical immunology. Philadelphia : W. B. Saunders, 1989. 548 p.

HALDAR, S.K.; SINGH, S.O.; MALLICK, B.B.; KATHURIA, B.K. Non-specific resistance against rabies virus in rabbits. Indian J. Anim. Health., v.16, p. 165$170,1977$.

HAUPT, H.; REHAAG, H. Raiva epizoótica nos rebanhos de Santa Catarina, sul do Brasil, transmitida por morcegos. Soc. Bras. Med. Vet., v.2, p.17-47, 1925.

HIROSE, J.A.M.; VILLEGAS, A.E.M. Estructura antigênica y mecanismos de infeccion del vírus de la rabia. Ciência Veterinária. v.7, p.68 -101, 1996.

HUBNER, S.O.; WEIBLEN, R.; SILVA, A.M.; MORAES, M.P. Evolução da imunidade passiva contra o herpesvírus bovino tipo 1. Cienc. Rural., v. 26, n. 3, p. 435-439, 1996.

INGRAM, D.G.; SMITH, A.N. Immunological responses of young animal. I Review of the literature. Can. Vet. J., v.6, n.8, p.194-205, 1965. 
ITO, F.H.; CORTES, J.A.; RWEYEMAMU, M.M.; UMEHARA, O.; MEDEIROS NETO, R.; DE LUCCA NETO, D.; BALTAZAR, M.; VASCONCELLOS, S.A.; VASCONCELLOS, M.E.P. Course of secondary humoral imune response shortly after revaccination with BHK-21 cell culture inactivaded rabies vaccine adjuvanted with aluminium hydroxide. Braz. J. Vet. Res. Anim. Sci., v.28, n.1, p.51-57, 1991.

JACKSON, A.C. Pathogenesis. In: JACKSON, A.C.; WUNNER, W.H. (Eds.). Rabies. 2.ed. London: Elsevier, 2007. p.341-381.

JUNIOR, C. Rebanho bovino volta a crescer após duas quedas, segundo o IBGE. Folha Online, São Paulo, 19 nov. 2009. Disponível em <htpp://www.folha.uol.com.br/folha/dinheiro>. Acesso em: 18 março 2010.

KOTAIT, I.; CARRIERI, M.L.; TAKAOKA, N.Y. RAIVA: aspectos gerais e clínica. São Paulo: Instituto Pasteur, 2009. Manuais, 8. 49p.

KREBS, J.W.; NOLL, H.R.; RUPPRECHT,C.E.; CHILDS, J.E. Rabies surveillance in the United States during 2001. J. Am. Vet. Med. Assoc., v.221, v.12, p.1690-17101, 2002.

LAFON, M. Immunology. In: JACKSON, A.C.; WUNNER, W.H. (Eds.). Rabies. 2.ed. London: Elsevier, 2007. p.489-504.

LANGOHR, I.M.; IRIGOYEN, L.F.; LEMOS, R.A.A.; BARROS, C.S.L. Aspectos epidemiológicos e clínicos e distribuição das lesões histológicas no encéfalo de bovinos com raiva. Ciênc. Rural, v.33, p.125-131, 2003.

LARGHI, O.P.; NEBEL, A.E. Duration of immunity afforded to cattle by a binaryethylenimine inactivated rabies vaccine. Zbl. Vet. Med.B., v. 32, p. 609-615, 1985. 
LEMOS, R.A.A.A.; BRUM, K.B.; MORI, A.E.; BONILHA, M.M.; KATAYAMA, K.A.; ANGREVES, G.M.; CAVALLERO, J.C.M. Doenças caracterizadas por sintomatologia nervosa em bovinos em Mato Grosso do Sul. In: BARROS, C.S.L.; LEMOS, R.A.A.; CAVALLERO, J.C.M. (Eds.). Manual de procedimentos para diagnóstico histopatológico diferencial da encefalopatia espongiforme bovina (BSE). São Paulo: Lemos, 2001. p.3148.

LEMOS, R.A.A. Enfermidades do sistema nervosa de bovinos de corte das regiões centro-oeste e sudeste do Brasil. 2005. 155f. Tese (Doutorado) Universidade Estadual Paulista, Jaboticabal, 2005.

LIMA, E.F.; RIET-CORREA, F.; CASTRO, R.S.; GOMES, A.A.B.; LIMA, F.S. Sinais clínicos, distribuição das lesões no sistema nervoso e epidemiologia da raiva em herbívoros na região Nordeste do Brasil. Pesqui. Vet. Bras., v.25, n.4, p.250-264, 2005.

MAHMOOD, A.K.; SHEIKH, M.A.; AKHTAR, S.; NABI, G.; RASHID, H.B. Duration of maternally derived antibodies against Pasteurella multocida in cow calves. Pakistan Vet. J., v.27, n. 2, p. 92-94, 2007.

MOLINA, L. Algumas considerações sobre a raiva bovina. Belo Horizonte: Rehagro, 2004.

MOREIN, B.; ABUSUGRA, I.; BLOMQVIST, G. Immunity in neonates. Vet. Immunol. Imunopathol., v.87, p.207-213, 2002.

MORI, A.E.; LEMOS, R.A.A. Raiva. In: LEMOS, R.A.A. (Ed.). Principais enfermidades de bovinos de corte do Mato Grosso do Sul: reconhecimento e diagnóstico. Campo Grande: UFMS, 1998. p.47-58.

MORI, A.E.; LEMOS, R.A.A.; KADRI, A. Raiva. In: LEMOS, R.A.A. (Ed.). Botulismo, meningoencefalite por herpesvirus tipo 5, poliencefalomalacia e raiva. Campo Grande: UFMS, 2004. p.63-82. 
OLIVEIRA, A.N.; ANDRADE, M.C.R.; SILVA, M.V.; MOURA, W.C.; CONTREIRAS, E.C. Immune response in cattle vaccinated against rabies. Mem. Inst. Oswaldo Cruz, v.95, n.1, p.83-88, 2000.

OLSEN, R.G.; KRAKOWKA, S. Immunology and immunopathology of domestic animals. Springfield: Charles C. Thomas, 1979. p.284-290.

ORGANIZATION PANAMERICANA DE LA SALUD. Boletín de vigilancia epidemiológica de la rabia en las Américas. Rio de Janeiro: Panaftosa, 2001. v.33, 41p.

ORGANIZATION PANAMERICANA DE LA SALUD. Boletín de vigilancia epidemiológica de la rabia en las Américas. Rio de Janeiro: Panaftosa, 2004. v.36, 40p.

PASTORET, P.P.; THIRIART, C.; THOMAS, I.; AGUILAR-SETIÉN, A.; BROCHIER, B.; SCHWERS, A. La vaccination antirabique des ruminants. Ann. Méd. Vét., v.129, p.339-349, 1985.

PAULETTI, P.; MACHADO, N. R.; PACKER, I. U.; BESSI, R. Avaliação de níveis séricos de imunoglobulina, proteína e o desempenho de bezerras da raça holandesa. Pesq. Agropec. Bras., v. 37, n. 1, p. 89-94, 2002.

PERINO, L.J.; WITTUM, T.E. Effects of various risk factors on plasma protein and serum immunoglobulin concentrations of calves at postpartum hours 10 and 24. Am. J. Vet. Res., v. 56, n. 9, p. 1144-1448, 1995.

PIZA, A.T.; PIERI, K.M.S.; LUSA, G.M.; CAPORALE, G.M.M.; TERRERAN, M.T.;MCHADO, L.A.; ZANETTI,C.R.B. Effect of contents and form of rabies glycoprotein on the potency of rabies vaccination in cattle. Mem. Inst. Oswaldo Cruz, v.97, n.2, p.265-268, 2002. 
PORTER, P. Immunoglobulins in bovine mammary secretions. Quantitatives changes in early lactacion and by the neonatal calf. Immunology, v.23, p.225229, 1972.

PORTER, P. Structural and functional characteristics of immunoglobulins of the common domestic especies. Adv. Vet. Sci. Comp. Med., v.23, p.1-21, 1979.

PRÉCAUSTA, P.; SOULEBOT, J.P.; BUGAND, M.; BRUN, A.; CHAPPUIS, G. Modelités de production et immunité conférré par un vaccin antirabique inactivé provenant de culture cellulaire. Comp. Immunol. Microbiol. Infect. Dis., v.5, p.217, 1982.

PUGH, D.G. Clínica de ovinos e caprinos. São Paulo: Roca, 2005. 513p.

QUEIROZ LIMA, E. Transmissão da raiva dos herbívoros pelos morcegos hematófagos da família Desmodontidae. Rev. Dep. Nac. Prod. Anim., v.1, p.165-173, 1934.

QUEIROZ LIMA, E. A transmissão da raiva bovina pelo morcego hematófago Desmodus rotundus. Brasil-médico, v.48, p.38-40, 1934.

QUEIROZ DA SILVA, L.H.; CARDOSO, T.C.; PERRI, S.H.V.; PINHEIRO, D.M.; CARVALHO, C. Pesquisa de anticorpos anti-rábicos em bovinos vacinados da região de Araçatuba, SP. Arq. Inst. Biol., v.70, n.4, p.407-413, 2003.

QUINN, P.J.; MARKEY, B.K.; CARTER, M.E.; DONNELLY, W.J.; LEONARD, F.C. Microbiologia veterinária e doenças infecciosas. 1.ed. Artimed: Porto Alegre, 2005. 511p.

RIET-CORREA, F.; SCHILD, A.L.; LEMOS,R.A.A.; BORGES, J.R.J. Doenças de Ruminantes e Eqüídeos. 3 ed. Santa Maria :Palloti, 2007. 722p.

RESENDE, F.C.B.; PASOLD, J.; FEREIRA, S.I.A.C.; ZANETTI, C.R.; LIMA, H.C. Vaccine Adjuvants: possibilities for use in humans or animals. Rev. Bras. Alerg. Imunopatol. v. 27, n. 3, p. 116-124, 2004. 
ROBISON, J.D.; STOT, G.H.; DENISE, S.K. Effects of passive immunity on growth and survival in the dairy heifer. J. Dairy Sci., v. 71, n. 5, p. 1283-1287, 1988.

RADOSTITS, O.M.; GAY, C.C.; BLOOD, D.C.; HINCHCLIFF, K.W. 2002. Doenças do recém-nascido. Clínica Veterinária: um tratado de doenças dos bovinos, ovinos, suínos, caprinos e equinos. 9. ed. Rio de Janeiro: Guanabara Koogan, 2002. p. 102-136.

ROSS, A.B.; FAVI, M.C.; VÁSQUEZ, A.V. Glicoproteína del vírus rábico: Estructura, inmunogenicidad y rol em la patogenia. Rev. Chil. Infectol., v.25, p. 14-18, 2008.

RUIZ, A.; ALVAREZ, E. Esfuerzos para la eliminación de la rabia humana transmitida por perro en las Americas. In: REUNION INTERNACIONAL SOBRE AVANCES EN LA INVESTIGACION Y CONTROL DE LA RABIA EN LAS AMERICAS, 9., 1998, México. Anais... México, 1998. p.144.

SANTOS, C.M.; KIMURA, H.; LONGO, I.M.; MENDES, N.F.; PEREIRA, O.A.C. Cell-mediated immune response antirabies vaccine in man. Allergol. Immunopathol., v.8, p.163-168, 1980.

SÃO PAULO (Estado). Coordenadoria de Defesa Agropecuária do Estado de São Paulo. Resolução SAA1, de 17 de Janeiro de 2002. Estabelece as normas para execução de projetos de controle de erradicação da anemia infecciosa equine, da febre aftosa e da raiva. Disponível em: <http://cda.sp.gov.br/>. Acesso em: 04 ago. 2009.

SEAG. Secretária de Agricultura, Pecuária e Pesca. Portal do Governo do Estado de Espírito Santo (Estado). Setor de Pecuária de Corte. Caracterização: população bovina 2007. Disponível em: http://www.seag.es.gov.br/>. Acesso em: 10 out. 2009. 
SCHNEIDER, M.C.; ALMEIDA, G.A.; SOUZA, L.M.; MORAES, N.B.; DIAZ, R.C. Controle da raiva no Brasil de 1980 a 1990. Rev. Saud. Pub. , v.30, n.2, p. 196-203,1996.

SIEGEL, S.; CASTELLAN, N.J. Nonparametric Statistics for Behavioral Sciences. New York: Megraw-Hill, 1988.

SINDAM. Sindicato Nacional das Indústrias de produtos para Saúde Animal. Vacinas: venda bate recorde. São Paulo: SIDAM, 2007. Disponível em: http://www.sindam.org/informações/noticia/>. Acesso em: 10 out. 2009.

SIKES, R.K. Present status of animal and human rabies vaccination. In: WORLD VETERINARY CONGRESS, 19., 1971, Mexico. Anais... Mexico, 1961. v.1, p.115-120.

SILVA, A.C.R.; CAPORALE, G.M.M.; GONÇALVES, C.A.; TARGUETA, M.C.; COMIN, F.; ZANETTI, R.; KOTAIT, I. Antibody response in cattle after vaccination with inactivated and attenuated rabies vaccines. Rev. Inst. Med. Trop. São Paulo, v.42, n.2, p.95-98, 2000.

SILVA, D.G.; MONTASSIER, H.J.; OLIVEIRA, R.G.; FUENTES, D.B.; SAMARA, S.I.; JEREZ, J.A.; BUZINARO, M.G. Evaluation of passive immunity in calves born from cows immunized with anti-rotavirus vaccine. Arq. Bras. Med. Vet. Zootec., v.60, n.5, p. 1089 - 1096, 2008.

SMITH, J.S.; YAGER, P.A.; BAER, G.M. A rapid reproducible test for determining rabies neutralizing antibodies. Bull. WHO,v. 48, n.5, p. 535-541, 1973.

SOULEBOT, J.P.; PRÉCAUSTA, P.; BRUM, A.; CHAPPUIS, G.; JERRÉ, J.; JAVRE, H.; PETERMANN, H.G. Prophylaxie de la rage animale (ou vétérinaire) par un vaccin inactivé monovalent ou associé. In: IABS CONGRESS VACCINATIONS IN THE DEVOLOPING COUNTRIES, 15., 1978, La Guadeloup. Anais... La Guadeloup, 1978. p.389. 
SUREAU, P.; ARELLANO, C. Epizootiología de la rabia paralítica bovina. In: WORLD VETERINARY, 19., 1971, Mexico. Papers and short communications. Mexico, 1971. v.1, p.28-31.

TIZARD, I.R. Veterinary Immunology. 7. ed. Philadelphia: W.B. Saunders, 2004. p. 221-233.

TORRES, S.; QUEIROZ LIMA, E. A raiva nos morcegos hematófagos (Desmodus rotundus murinus). Rev. Dep. Nac. Prod. Anim., v.2, n.4-6, p.385406, 1935.

UMEHARA, O.; DE LUCCA NETO, D.; MORO, E.; BERNARDI, F.; ITO, F.H.; RODRIGUES, C.A. Rabies virus neutralizing antibody profile in cattle vaccinated with inactivated vaccine adjuvanted with either aluminium hydroxide alone or combined with avridine. Arq. Inst. Biol., v.69, n.1, p.23-28, 2002.

VAN KAMPEN, R..K. Rabies: Guidelines for medical professionals Trenton: Veterinary Learning Systems, 1999. 88 p.

WADA, M.Y. Raiva animal no Brasil, 2007. Brasília: Ministério da Saúde, Secretaria de Vigilância em Saúde, 2008. Disponível em: <http:// saude.gov.br/svs>. Acesso em: 10 ago. 2009.

WADA, M.Y. Raiva animal no Brasil, 2008. Brasília: Ministério da Saúde, Secretaria de Vigilância em Saúde, 2008. Disponível em: <http:// saude.gov.br/svs>. Acesso em: 10 ago. 2009.

WEAVER, D.M.; TYLER, J.W.; VANMETRE, D.C.; HOSTETLER, D.E.; BARRINGTON, G.M. Passive transfer of colostral immunoglobulins in calves. J. Vet. Interm. Med., v. 14, n. 6, p. 569-577, 2000.

WIKTOR, T.J. Introduction à l'étude des varians antigéniques du virus rabique.

Comp. Immunol. Microbiol. Infect. Dis., v.5, p.93-94, 1982. 
WOOLUMS, A. Vaccinating calves: New information on the effects of maternal immunity. AABP Proc., v. 40, p. 10-16, 2007.

WORLD HEALTH ORGANIZATION. Expert consultation on rabies: first report. Geneve: World Health Organization, 2004. 121p. (WHO Technical Report Series, 931).

WORLD HEALT ORGANIZATION. Rabies. Geneva: WHO, 2006. Fact sheet, n.99.

WORLD HEALTH ORGANIZATION. Expert consultation on rabies. Geneva: World Health Organization, 2008. (Technical Report Series, 840). Disponível em: <http://www.who.int/rabies/epidemiology/en/>. Acesso em: 13 jun. 2009.

WUNNER, W.H. Immunology. In: JACKSON, A.C.; WUNNER, W.H. (Eds.). Rabies. 2.ed. London: Elsevier, 2007. p.23-68.

ZANETTI, C.R. Imunidade anti-rábica. In: SEMINÁRIO INTERNACIONAL DE RAIVA, 2003, São Paulo. Resumos... São Paulo: Instituto Pasteur, 2003. p.3334.

ZIMMERMAN, A.D.; BOOTS, R.E.; VALLI, J.L.; CHASE, C.C. Evaluation of protection against virulent bovine viral diarrhea virus type 2 in calves that had maternal antibodies and were vaccinated with a modified-live vaccine. J. Am. Méd. Assoc., v. 228, n. 11, p. 1757-1761, 2006. 
Anexos 


\section{ANEXO 1}

Tabela 1 - Títulos de AcSN antirrábicos em vacas revacinadas no $7^{\circ}$ mês de gestação, 48 horas após o parto. Resultados da prova de soroneutralização em cultivo celular, expresso em UI (Unidades Internacionais)

\begin{tabular}{cccccccc}
\hline $\begin{array}{c}N^{0} \text { vacas } \\
\text { lote 1 }\end{array}$ & $\begin{array}{c}\text { Título } \\
\text { AcSN }\end{array}$ & $\begin{array}{c}\mathrm{N}^{\mathrm{O}} \\
\text { vacas } \\
\text { lote 2 }\end{array}$ & $\begin{array}{c}\text { Título } \\
\text { AcSN }\end{array}$ & $\begin{array}{c}\mathrm{N}^{\mathrm{O}} \\
\text { vacas } \\
\text { lote 3 }\end{array}$ & $\begin{array}{c}\text { Título } \\
\text { AcSN }\end{array}$ & $\begin{array}{c}\mathrm{N}^{\mathrm{o}} \text { vacas } \\
\text { lote 4 }\end{array}$ & $\begin{array}{c}\text { Título } \\
\text { AcSN }\end{array}$ \\
\hline 253 & 1,06 & 386 & 1,06 & 1110 & 1,06 & 304 & 1,06 \\
335 & 0,53 & 108 & 0,8 & 224 & 1,06 & 250 & 1,06 \\
167 & 1,06 & 316 & 0,8 & 72 & 1,06 & 529 & 1,06 \\
29 & 0,8 & 412 & 1,06 & 1348 & 1,06 & 340 & 1,06 \\
1290 & 1,06 & 401 & 1,06 & 520 & 1,06 & 413 & 1,06 \\
1139 & 1,06 & 427 & 1,06 & 570 & 0,53 & 79 & 1,06 \\
268 & 1,06 & 955 & 1,06 & 407 & 1,06 & 292 & 1,06 \\
541 & 1,06 & 149 & 1,06 & 522 & 1,06 & 530 & 0,8 \\
109 & 1,06 & 221 & 1,06 & 249 & 1,06 & 536 & 1,06 \\
101 & 1,06 & 564 & 0,8 & & & 1325 & 0,8 \\
\hline
\end{tabular}

Lotes 1, 2 e 3 representam os títulos de AcSN antirrábicos das mães dos bezerros vacinados aos 6, 4 e 2 meses de idade enquanto que o lote 4 corresponde aos títulos de AcSN das mães dos bezerros não vacinados.

Tabela 2 - Títulos de AcSN antirrábicos, nos diferentes momentos em bezerros filhos de mães revacinadas, correspondente ao grupo de animais não vacinados. Resultados da prova de soroneutralização em cultivo celular, expressos em UI (Unidades Internacionais)

Bezerros não vacinados filhos de mães revacinadas

\begin{tabular}{|c|c|c|c|c|c|c|c|c|c|c|c|c|c|}
\hline & $0 \mathrm{~d}^{*}$ & $1 \mathrm{~m}$ & $2 m$ & $3 m$ & $4 m$ & $5 \mathrm{~m}$ & $6 \mathrm{~m}$ & $7 \mathrm{~m}$ & $8 m$ & $9 m$ & $10 \mathrm{~m}$ & $11 \mathrm{~m}$ & $12 m$ \\
\hline 755 & 1,06 & 1,06 & 1,06 & 1,06 & 0,8 & 0,26 & 0,4 & 0,13 & 0,13 & 0,26 & 0,26 & 0,26 & 0,26 \\
\hline 756 & 1,06 & 0,8 & 1,06 & 0,56 & 0,4 & 0,8 & 0,13 & 0,13 & 0,13 & 1,06 & 0,26 & 0,26 & 0,52 \\
\hline 757 & 1,06 & 1,06 & 0,8 & 0,26 & 0,26 & 0,26 & 0,13 & 0,13 & 0,13 & 1,06 & 1,06 & 1,06 & 1,06 \\
\hline 758 & 1,06 & 1,06 & 0,8 & 1,06 & 1,06 & 0,8 & 0,4 & 0,2 & 0,13 & 0,26 & 0,26 & 0,8 & 1,06 \\
\hline 759 & 0,8 & 0,8 & 0,26 & 0,26 & 0,13 & 0,13 & 0,13 & 0,2 & 1,06 & 0,53 & 0,13 & 0,8 & 0,52 \\
\hline 760 & 1,06 & 1,06 & 0,8 & 0,8 & 0,13 & 0,13 & 0,13 & 0,13 & 0,13 & 1,06 & 1,06 & 1,06 & 1,06 \\
\hline 761 & 1,06 & 1,06 & 0,8 & 0,4 & 0,53 & 0,13 & 0,13 & 0,13 & 0,13 & 0,26 & 1,06 & 1,06 & 1,06 \\
\hline 762 & 0,8 & 1,06 & 0,4 & 0,4 & 0,53 & 0,13 & 0,2 & 0,13 & 0,13 & 1,06 & 1,06 & 1,06 & 1,06 \\
\hline 763 & 1,06 & 1,06 & 1,06 & 1,06 & 0,53 & 0,53 & 0,13 & 0,26 & 0,13 & 1,06 & 1,06 & 1,06 & 1,06 \\
\hline 764 & 1,06 & 1,06 & 1,06 & 0,8 & 0,8 & 1,06 & 0,13 & 0,13 & 0,13 & 0,13 & 1,06 & 1,06 & 1,06 \\
\hline
\end{tabular}

* colheita 48 horas após o nascimento 
Tabela 3 - Títulos de AcSN antirrábicos, nos diferentes momentos em bezerros filhos de mães revacinadas, correspondente ao grupo de animais vacinados com seis meses de idade. Resultados da prova de soroneutralização em cultivo celular, expressos em UI (Unidades Internacionais)

Bezerros vacinados com 6 meses de idade filhos de mães revacinadas

\begin{tabular}{|c|c|c|c|c|c|c|c|c|c|c|c|c|c|c|c|}
\hline & $0 \mathrm{~d}^{*}$ & $1 \mathrm{~m}$ & $2 m$ & $3 m$ & $4 m$ & $5 \mathrm{~m}$ & $6 m^{\star \star}$ & PV 1 & $7 m^{\star \star \star}$ & PV2 & $8 m$ & $9 m$ & $10 \mathrm{~m}$ & $11 \mathrm{~m}$ & $12 m$ \\
\hline 765 & 1,06 & 1,06 & 1,06 & 0,8 & 0,26 & 0,2 & 0,13 & 0,26 & 1,06 & 1,06 & 0,8 & 1,06 & 1,06 & 1,06 & 1,06 \\
\hline 766 & 0,8 & 0,52 & 0,52 & 0,26 & 0,2 & 0,2 & 0,13 & 0,13 & 1,06 & 1,06 & 1,06 & 1,06 & 1,06 & 1,06 & 1,06 \\
\hline 767 & 0,8 & 0,52 & 0,2 & 0,13 & 0,13 & 0,2 & 0,8 & 0,13 & 1,06 & 1,06 & 1,06 & 1,06 & 1,06 & 1,06 & 1,06 \\
\hline 768 & 1,06 & 0,8 & 0,52 & 0,4 & 0,13 & 0,2 & 0,13 & 0,13 & 0,4 & 1,06 & 0,8 & 1,06 & 1,06 & 1,06 & 1,06 \\
\hline 770 & 1,06 & 1,06 & 1,06 & 1,06 & 1,06 & 1,06 & 0,2 & 0,26 & 0,53 & 1,06 & 0,8 & 1,06 & 1,06 & 1,06 & 1,06 \\
\hline 771 & 1,06 & 1,06 & 1,06 & 0,8 & 0,53 & 0,8 & 0,4 & 0,52 & 0,8 & 1,06 & 1,06 & 1,06 & 1,06 & 1,06 & 1,06 \\
\hline 772 & 1,06 & 1,06 & 1,06 & 0,53 & 0,2 & 0,26 & 0,4 & 1,06 & 1,06 & 1,06 & 1,06 & 1,06 & 0,8 & 1,06 & 1,06 \\
\hline 773 & 1,06 & 1,06 & 1,06 & 1,06 & 1,06 & 0,8 & 1,06 & 0,13 & 1,06 & 1,06 & 1,06 & 1,06 & 1,06 & 0,52 & 1,06 \\
\hline 774 & 1,06 & 1,06 & 1,06 & 1,06 & 0,8 & 0,8 & 0,4 & 1,06 & 0,8 & 1,06 & 0,8 & 1,06 & 1,06 & 0,52 & 1,06 \\
\hline 775 & 1,06 & 1,06 & 1,06 & 0,53 & 0,2 & 0,26 & 0,4 & 0,52 & 0,4 & 1,06 & 0,26 & 1,06 & 1,06 & 1,06 & 1,06 \\
\hline
\end{tabular}


Tabela 4 - Títulos de AcSN antirrábicos, nos diferentes momentos em bezerros filhos de mães revacinadas, correspondente ao grupo de animais vacinados com quatro meses de idade. Resultados da prova de soroneutralização em cultivo celular, expressos em UI (Unidades Internacionais)

Bezerros vacinados com 4 meses de idade filhos de mães revacinadas

\begin{tabular}{ccccccccccccccccc}
\multicolumn{8}{c}{ Bezerros vacinados com 4 meses de idade filhos de mães revacinadas } \\
\hline 776 & 1,06 & 1,06 & 1,06 & 0,4 & 0,2 & 0,13 & 0,2 & 1,06 & 0,26 & 0,26 & 0,8 & 1,06 & 0,8 & 1,06 & 1,06 \\
777 & 1,06 & 1,06 & 0,8 & 0,26 & 0,13 & 0,13 & 0,26 & 1,06 & 1,06 & 1,06 & 1,06 & 1,06 & 1,06 & 1,06 & 0,8 \\
778 & 1,06 & 1,06 & 0,52 & 0,4 & 0,2 & 0,26 & 1,06 & 1,06 & 1,06 & 1,06 & 1,06 & 1,06 & 1,06 & 1,06 & 1,06 \\
779 & 1,06 & 1,06 & 1,06 & 0,8 & 0,4 & 0,26 & 0,2 & 1,06 & 1,06 & 1,06 & 1,06 & 1,06 & 1,06 & 1,06 & 0,26 \\
780 & 1,06 & 1,06 & 0,52 & 0,4 & 0,13 & 0,13 & 1,06 & 0,8 & 0,4 & 0,26 & 0,4 & 0,13 & 0,26 & 1,06 & 0,26 \\
781 & 1,06 & 1,06 & 1,06 & 0,8 & 0,53 & 1,06 & 0,4 & 1,06 & 0,52 & 0,2 & 0,26 & 1,06 & 1,06 & 1,06 & 1,06 \\
783 & 1,06 & 1,06 & 1,06 & 0,8 & 0,26 & 0,13 & 0,26 & 1,06 & 0,52 & 0,2 & 0,8 & 0,53 & 1,06 & 1,06 & 1,06 \\
784 & 1,06 & 1,06 & 1,06 & 1,06 & 0,8 & 0,52 & 0,53 & 0,52 & 0,53 & 0,4 & 0,8 & 0,53 & 0,53 & 1,06 & 0,8 \\
785 & 1,06 & 0,8 & 0,8 & 0,4 & 0,13 & 0,13 & 0,2 & 1,06 & 0,26 & 0,13 & 0,53 & 1,06 & 1,06 & 1,06 & 0,8 \\
786 & 1,06 & 1,06 & 1,06 & 0,8 & 1,06 & 0,52 & 0,26 & 1,06 & 0,26 & 0,2 & 0,26 & 0,13 & 0,26 & 1,06 & 0,8 \\
\hline
\end{tabular}

* colheita 48 horas após nascimento; ** vacina com quatro meses de idade; ${ }^{* \star \star}$ revacinação

$\mathrm{PV} 1=15$ dias após primeira vacina

PV2 = 15 dias após revacinação 
Tabela 5 - Títulos de AcSN antirrábicos, nos diferentes momentos em bezerros filhos de mães revacinadas, correspondente ao grupo de animais vacinados com dois meses de idade. Resultados da prova de soroneutralização em cultivo celular, expressos em UI (Unidades Internacionais)

Bezerros vacinados com 2 meses de idade filhos de mães revacinadas

\begin{tabular}{|c|c|c|c|c|c|c|c|c|c|c|c|c|c|c|c|}
\hline & $0 d^{*}$ & $1 \mathrm{~m}$ & $2 m^{\star \star}$ & PV1 & $3 m^{\star \star *}$ & PV2 & $4 m$ & $5 \mathrm{~m}$ & $6 m$ & $7 m$ & $8 m$ & $9 m$ & $10 \mathrm{~m}$ & $11 \mathrm{~m}$ & $12 \mathrm{~m}$ \\
\hline 787 & 1,06 & 1,06 & 0,52 & 0,2 & 0,4 & 1,06 & 1,06 & 0,8 & 0,8 & 0,26 & 1,06 & 1,06 & 1,06 & 0,26 & 0,26 \\
\hline 788 & 1,06 & 1,06 & 1,06 & 0,8 & 0,8 & 1,06 & 1,06 & 1,06 & 1,06 & 0,13 & 0,53 & 1,06 & 1,06 & 1,06 & 1,06 \\
\hline 789 & 1,06 & 1,06 & 0,8 & 0,26 & 0,2 & 1,06 & 0,4 & 0,8 & 0,4 & 0,2 & 0,2 & 1,06 & 1,06 & 0,26 & 0,26 \\
\hline 790 & 0,8 & 1,06 & 0,4 & 0,52 & 0,13 & 0,4 & 0,2 & 0,4 & 0,26 & 0,26 & 0,13 & 1,06 & 1,06 & 0,26 & 0,26 \\
\hline 791 & 1,06 & 1,06 & 1,06 & 0,8 & 0,8 & 1,06 & 1,06 & 0,4 & 0,4 & 0,2 & 1,06 & 0,26 & 1,06 & 1,06 & 0,26 \\
\hline 792 & 1,06 & 0,8 & 0,52 & 0,4 & 0,13 & 0,8 & 0,26 & 0,26 & 0,8 & 0,8 & 1,06 & 1,06 & 1,06 & 1,06 & 1,06 \\
\hline 793 & 1,06 & 1,06 & 1,06 & 1,06 & 0,8 & 0,8 & 0,8 & 1,06 & 0,13 & 0,8 & 1,06 & 0,53 & 1,06 & 1,06 & 0,8 \\
\hline 794 & 1,06 & 1,06 & 1,06 & 1,06 & 1,06 & 0,8 & 1,06 & 0,53 & 0,2 & 0,13 & 0,13 & 0,53 & 1,06 & 1,06 & 0,8 \\
\hline 795 & 1,06 & 1,06 & 1,06 & 1,06 & 1,06 & 1,06 & 1,06 & 0,26 & 0,4 & 0,13 & 0,13 & 0,26 & 1,06 & 1,06 & 1,06 \\
\hline
\end{tabular}

* colheita 48 horas após nascimento; ** vacina com dois meses de idade; *** revacinação

$\mathrm{PV} 1=15$ dias após primeira vacina

PV2 = 15 dias após revacinação 


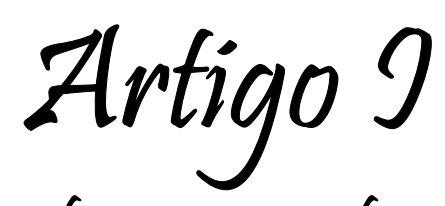

Importance of antirabies revaccination for an adequate antirabies protection in newborn. 


\title{
Importance of antirabies revaccination for an adequate antirabies protection in newborn.
}

\author{
Filho,O.A. ${ }^{1}$; Megid,J*1.;Geronutti L ${ }^{1}$.,Ratti Jr J ${ }^{3}$., Kataoka, A.P.A.G.; Martorelli,L.F.A ${ }^{2 .}$
}

The placenta of ruminants is syndesmochorial preventing the passage of immunoglobulins molecules, so the newborns are entirely dependent on antibodies received through the colostrum. They rely exclusively on passive immunity absorbed from maternal colostrum for their protection against infection during the first weeks of their life. The objective of this work was evaluate the transfer of anti-rabies immunoglobulin in cows primevaccinated and revaccinated against rabies and the correlation to the offsprings sera titers 48 hours after birth. Females not vaccinated, first vaccinated and revaccinated against rabies at the final third of pregnancy were studied. Forty eight hours after parturition blood from dams and offsprings were collected and the anti-rabies neutralizing sera titers analyzed. Sera of all animals were tested for rabies virus neutralizing antibody by RFFIT or SFIMT. The conventionally defined FAVN level of $0.5 \mathrm{IU} / \mathrm{mL}$ was considered as a cut-off for rabies protection. No statistical significant difference was observed between sera titers from dams and their offsprings but statistical significant difference was observed between sera titers from primevaccinated and revaccinated dams and also between offsprings born from dams primevaccinated or revaccinated against rabies. In addition only $50 \%$ of mothers primevacinated and $30 \%$ of their offsprings had protective titers contrarily to revaccinated dams and their offsprings that presented $100 \%$ of protective titers. The results characterize the importance of revaccination for a better colostral antibodies transfer and offsprings protection against rabies.

1- UNESP- School of Veterinary Medicine and Animal Science- Departament of Veterinary Hygiene and Public HealthBotucatu-SP, Brasil

2- Zoonosis Control Center - Rabies Laboratory - São Paulo-SP, Brasil

3- UNESP- School of Veterinary Medicine and Animal Science- *email:jane@fmvz.unesp.br 


\section{Introduction}

2

According to Panamerican Health Organization (OPAS, 2004), 2797 cases of

4 rabies in cattle were reported in 2004 in the countries of the Americas, $87 \%$ more cases

5 than in 2002. Of these, 2591 (92.6\%) occurred in Latin America; 130 (4.6\%) in North

6 America and 76 in Caribbean and Guatemala. In Latin America, Brazil had 60.6\% of

7 cases, followed by $13 \%$ in Mexico and $8 \%$ in the Andes.

There's no predisposition of race, sex or age, but a greater prevalence of the

9 disease can be observed in young animals (Langohr et al., 2003). The occurrence of

10 numerous cases in calves under one year of age may be related mainly to immunity in

11 this age, since in this phase occurs the lacking of colostral immunity and the animals

12 have not been vaccinated against rabies, or if received the first vaccine, in most cases,

13 not received the vaccinal booster (Lemos et al., 2001; Mori et al., 2004).,

14 In a study by Lima et al. (2005), in 25 cases of bovine rabies diagnosed in a veterinary hospital of Federal University of Paraíba, Campina Grande, higher prevalence was observed in young animals, with less than two years of age. The authors correlated this to the lower immunity of these animals that were not re-vaccinated after 30 days of the first vaccination, performed to three and four months of age. The same

19 situation was observed in Mato Grosso do Sul where an increased prevalence in young animals was also noted (Langhr et al., 2003; Mori et al. 2004). a good indicator of the effectiveness of vaccine used (Atanasiu, 1973). 
In a study with 35 cattle, Albas et al., (1998) reported that booster doses of

2 vaccination induced higher titers of antibodies. The authors observed that $19 \%$ of who

3 received a dose of booster 30 days after vaccination maintained anti-rabies antibodies

4 titers greater or equal to $0,5 \mathrm{UI} / \mathrm{mL}$ after 360 days, as opposed to the group that did not

5 receive the booster, where only 4,7\% presented titer equal to $0,5 \mathrm{UI} / \mathrm{mL} 270$ days after.

This same group of researchers (Albas et al., 2006), following this same subject

7 compared three groups of animals ( $a, b$ and c) using three alternative protocols of

8 immunization with rabies inactivated vaccine. The Group A received a single dose of

9 vaccine, the group B received a booster after 30 days and group C a booster 30 and 180

10 days after the first immunization. The results demonstrated that Group C presented

11 higher and more persistent anti-rabies antibodies titers compared to the two other 12 groups.

Some researchers also reported similar results confirming that the immune response induced by only one vaccine dose does not induce high antibodies titers (Silva et al., 2000; Umehara et al., 2002; Queiroz Silva et al., 2003; Piza et al., 2002). However, where doses of booster are done, the seraneutralizing antibodies titers

17 become significantly higher (Albas et al., 1998; Oliveira et al., 2000).

Compared with active immunity described above, passive immunity transferred through colostrum to calves after birth, has a limited duration, having been verified that

20 it is detected for a relatively short period, while immunity actively induced by 21 vaccination is in many cases more lasting. The newborn ungulates have initial 22 protection achieved by passive transfer of immunoglobulin (Ig) from mother to newborn 23 (Porter, 1972). The transfer of the maternal antibodies to fetus is determined by the 
1 structure of the placenta. The placenta of ruminants is syndesmocorial. This type of

2 placenta prevents the passage of Ig molecules to the fetus and newborn are so dependent

3 on antibodies received through colostrum (Champpuis, 1998; Eliozondo-Salazar \&

4 Heinrichis, 2008).

5 In cattle, it is essential that the calves ingest the colostrum until 24 hours post

6 birth, once the concentration of intestinal proteolityc enzymes is very low in the first

7 hours after birth and the immunoglobulins obtained through ingestion of colostrum

8 reach the small intestine where they are absorbed reaching the epithelial cells by

9 pinocytosis, passing completely inside the intestinal capillaries reaching the circulatory

10 system resulting in massive Ig absorption (Champpuis, 1998).

11 Failure of colostral appropriate antibodies transfer can occur due to some factors

12 such as insufficient quantity or poor quality of colostrum production, volume of

13 ingested colostrum, Ig concentration in colostrum, age at first pregnancy of the cow and

14 weight of calf at birth (Chase et al., 2008, Eliozondo-Salazar \& Heinrichis, 2008).

15 The acquisition of passive immunity in neonates is dependent on the ingestion

16 and absorption of appropriate quantities of Ig from colostrum, essential to provide

17 protection to at least the first two to four weeks of life (Porter, 1979; Chase et al., 2008).

18 The objective of this work was evaluate the transfer of antirabies

19 immunoglobulin of dams primevaccinated and revaccinated against rabies and the

20 correlation to the offsprings sera titers 48 hs after birth 


\section{Material and Methods}

2

3 Pregnant females not vaccinated and previously vaccinated against rabies were

4 submitted to anti-rabies vaccine at the final third of pregnancy. Forty eight hours after 5 parturition blood from dams and offsprings were collected and the anti-rabies

6 neutralizing sera titers analyzed. Sera of all animals were tested for rabies virus

7 neutralizing antibody by RFFIT (Smith et al., 1973; Favoreto et al., 1993). The

8 conventionally defined VNA level of $0.5 \mathrm{IU} / \mathrm{ml}$ for humans was considered as a cut-off

9 for rabies immunization (Albas et al., 1998).

10 The results were evaluated comparatively between the titers of cows

11 primevaccinated and revaccinated and correlated to the seraneutralizing titers presented

12 by their calves using non parametric statistic ( Instat software)

\section{Results and discussion}

In this work the anti-rabies antibodies titers in vaccinated and revaccinated cows

17 was evaluated and correlated to the titer of their calves. The results obtained showed the

18 presence of seraneutralizing antibodies titers higher than $0,5 \mathrm{UI} / \mathrm{mL}$, 48 hours after the

19 birth of their calves, in all revaccinated cows. Statistically significant difference was

20 demonstrated for the anti-rabies antibodies titers in cows first vaccinated compared to

21 revaccinated cows, as well as for calves born from first vaccinated cows compared to

22 revaccinated ones (Figs 1 to 4). Different results were obtained by Geronutti (2002)

23 that studied in your research cows first vaccinated against rabies, also in the final period

24 of gestation. The author reported absence of protecting titers in nine $(35,7 \%)$ of 30 
1 cows evaluated after the birth of calves and justified the results as possible vaccination

2 failure due to a single dose of vaccine, in agreement with the work carried out by Albas

3 et al., (1998) that reinforced the need of a booster to induce persistent titers of

4 antibodies in vaccinated animals.

5 Other researchers also reported similar results, since the immune response

6 induced by only one vaccine did not induce high titers of antibodies (Silva et al., 2000,

7 Umehara et al., 2002; Queiroz Silva et al., 2003; Piza et al., 2002). However, when

8 booster are done, titers become significantly higher (Albas et al., 1998; Oliveira et al.,

9 2000; Albas et al., 2006), results, consistent with the observed in our research, 10 evaluating revaccinated cows.

11 Higher or similar antibodies titers have been observed in calves comparatively to

12 titers of their respective mothers, 48 hours after birth and colostrum ingestion, 13 indicating the transfer of colostral antibodies in all lots of animals. These results are 14 contrary to Bunn (1988) and Geronutti (2002), when assessing the transfer of colostral 15 antibodies in calves born from first vaccinated cows, observed that the titer of calves 16 was extremely lower and not correlated with the mother titer after the birth.

17 Anti-rabies antibodies titers were observed from birth until 4th month in all lots 18 of calves studied in this work, with half lives of antibodies acquired passively by 19 colostrum in disagreement to Geronutti (2002) that found antibodies titers from 30 days 20 to 60 days of age in calves born from prime vaccinated cows reinforcing the need and 21 importance of maternal revaccination for adequate immunity transfer through colostrum 22 to their descendants. 
1 Thus the results demonstrated that revaccination against rabies, during

2 pregnancy, induces neutralizing antibodies titers in protectors levels transferred directly

3 to calves through colostrum and these antibodies remains for a variable period of three

4 to four months in calves born from cows revaccinated during pregnancy contrarily to

5 mothers first vaccinated that presented and transferred lower and less persistent titers of

6 antibodies to their calves.

7

8

9 Figure 1. Seraneutralizing antibodies titers, 48hours after parturition, in cows first 10

11

12 vaccinated and revaccinated against rabies (median and standard deviation)

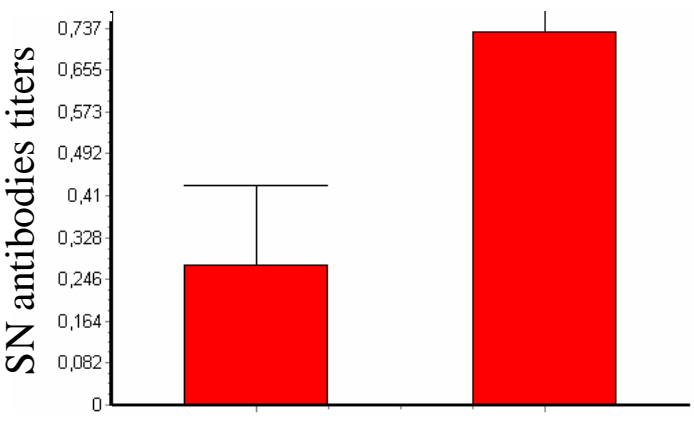

First vaccinated Revaccinated
Figure 2. Seraneutralizing antibodies titers, 48hours after birth, in calves born from cows first vaccinated and revaccinated against rabies (median and standard deviation)

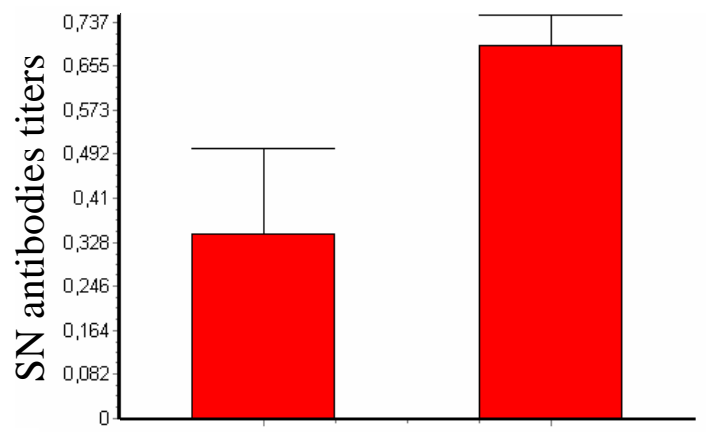

First vaccinated Revaccinated 


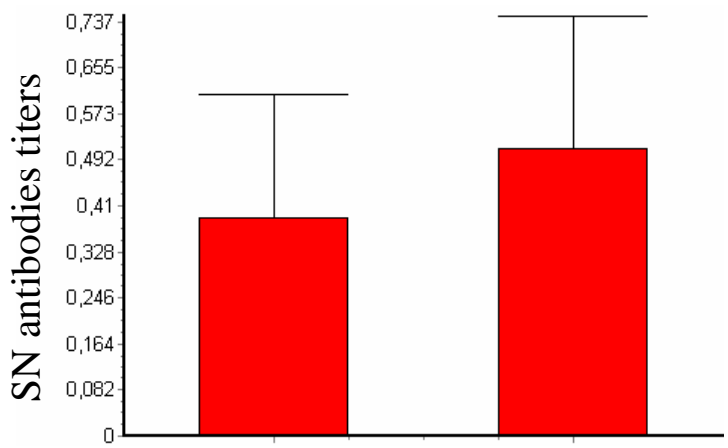

calves

dams

4 Figure 3.Seraneutralizing antibodies titers in cows first vaccinated against rabies and 5 their offsprings titers, 48hours after parturition (median and standard deviation).

6

7

8

11 Figure 4. Seraneutralizing antibodies titers in cows revaccinated against rabies and their

12 offsprings titers, 48hours after parturition (median and standard deviation).

13

14

15

16

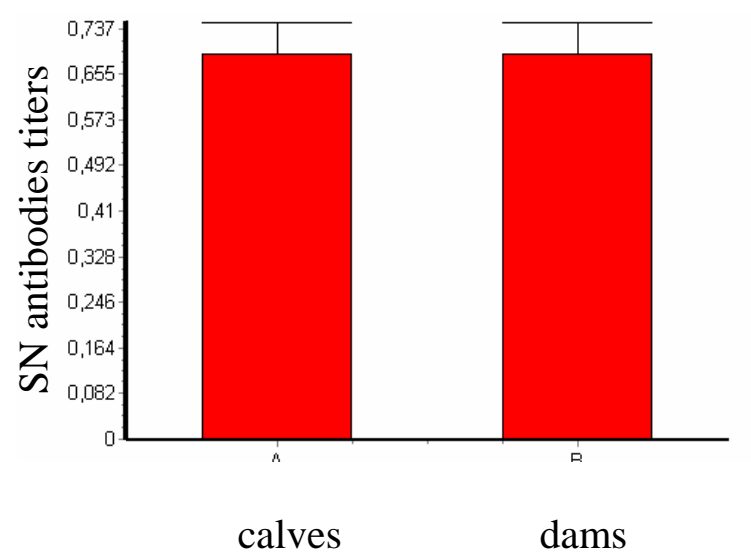




\section{Bibliographic references}

2

3 Albas, A.; Pardo, P.E.; Gomes, A.A.B.; Bernardi, F.; Ito F.H. Effect of a booster-dose 4 of rabies vaccine on the duration of virus neutralizing antibody titers in bovines. Rev.

5 Soc. Bras. Med. Trop., v.4, p.367-371, 1998.

6

7 Albas, A.; Fontolan, O.L.; Pardo, P.E.; Bremer Neto, H.; Sartori, A. Interval between

8 first dose and booster affected antibody production in cattle vaccinated against rabies. $\mathbf{J}$.

9 Venom. Anim. Toxins incl. Trop. Dis., v.12, n.3, p.476-486, 2006.

11 Atanasiu, P. Quantitative assay and potency test of antirabies serum and 12 immunoglobulin. WHO Monogr. Serv., v.23, n.314, p. 314-318, 1973.

14 Bunn, T.O. Vaccines and vaccination of domestic animals. In: Campbell, J.B.; Charlton, 15 K.M. Rabies. Boston: Kluwer, 1988. v.2, p.321-333.

17 Champuis, G. Neonatal immunity and immunization in early age: lessons from veterinary medicine. Vaccine, v.16, n.13, p.1468-1472, 1998.

20 Chase, C.C.L.; Hurley, D.J.; Reber, A.J. Neonatal immune development in the calf and 21 its impact on vaccine response. Vet. Clin. Food Anim., v.24, p.87-104, 2008.

23 Elizondo-Salazar, J.A.; Heinrichs, A.J. Review: Heat Treating Bovine Colostrum.

24 Profes. Anim. Sci.. v. 24, p 530-538, 2008. 
1 Favoretto, S.R.; Carrieri, M.L.; Tino, M.S.; Zanetti, C.R.; Pereira, O.A.C. Simplified

2 fluorescent inhibition microtest for the titration of rabies neutralizing antibodies. Rev.

3 Inst. Med. Trop. São Paulo, v.35, n.2, p.171-175, 1993.

5 Geronutti, L.M. 2002. Vacinação antirrábica em bezerros: resposta imune humoral e

6 interferência de anticorpos colostrais. 83f. Dissertação (Mestrado) - Faculdade de

7 Medicina Veterinária, Universidade Estadual Paulista, Botucatu.

8

9 Langohr, I.M.; Irigoyen, L.F.; Lemos, R.A.A.; Barros, C.S.L. Aspectos epidemiológicos

10 e clínicos e distribuição das lesões histológicas no encéfalo de bovinos com raiva.

11 Ciênc. Rural, v.33, p.125-131, 2003.

13 Lemos, R.A.A.A.; Brum, K.B.; Mori, A.E.; Bonilha, M.M.; Katayama, K.A.; Angreves, 14 G.M.; Cavallero, J.C.M. Doenças caracterizadas por sintomatologia nervosa em bovinos em Mato Grosso do Sul. In: Barros, C.S.L.; Lemos, R.A.A.; Cavallero, J.C.M. (Eds.). Manual de procedimentos para diagnóstico histopatológico diferencial da encefalopatia espongiforme bovina (BSE). São Paulo: Lemos, 2001. p.31-48.

Lima, E.F.; Riet-Correa, F.; Castro, R.S.; Gomes, A.A.B.; Lima, F.S. Sinais clínicos, distribuição das lesões no sistema nervoso e epidemiologia da raiva em herbívoros na região Nordeste do Brasil. Pesqui. Vet. Bras., v.25, n.4, p.250-264, 2005.

Mori, A.E.; Lemos, R.A.A.; Kadri, A. Raiva. In: Lemos, R.A.A. (Ed.). Botulismo, meningoencefalite por herpesvirus tipo 5 , poliencefalomalacia e raiva. Campo 
1 Oliveira, A.N.; Andrade, M.C.R.; Silva, M.V.; Moura, W.C.; Contreira, E.C. Immune

2 response in cattle vaccinated against rabies. Mem. Inst. Oswaldo Cruz, v.95, n.1, p.83-

$388,2000$.

4

5 Organization Panamericana de La Salud. Boletín de vigilancia epidemiológica de la

6 rabia en las Américas. Rio de Janeiro: Panaftosa, 2004. v.36, 40p.

7

8 Piza, A.T.; Pieri, K.M.S.; Lusa, G.M.; Caporale, G.M.M.; Terreran, M.T.; Machado,

9 L.A.; Zanetti,C.R.B. Effect of contents and form of rabies glycoprotein on the potency 10 of rabies vaccination in cattle. Mem. Inst. Oswaldo Cruz, v.97, n.2, p.265-268, 2002.

Porter, P. Immunoglobulins in bovine mammary secretions. Quantitatives changes in early lactacion and by the neonatal calf. Immunology, v.23, p.225-229, 1972.

Porter, P. Structural and functional characteristics of immunoglobulins of the common domestic especies. Adv. Vet. Sci. Comp. Med., v.23, p.1-21, 1979.

Queiroz da Silva, L.H.; Cardoso, T.C.; Perri, S.H.V.; Pinheiro, D.M.; Carvalho, C. Pesquisa de anticorpos antirrábicos em bovines vacinados da região de Araçatuba, SP. Arq. Inst. Biol., v.70, n.4, p.407-413, 2003.

22 Silva, A.C.R.; Caporale, G.M.M.; Gonçalves, C.A.; Targueta, M.C.; Comin, F.; Zanetti, R.; Kotait, I. Antibody response in cattle after vaccination with inactivated and attenuated rabies vaccines. Rev. Inst. Med. Trop. São Paulo, v.42, n.2, p.95-98, 2000. 
1 Smith, J.S.; Yager, P.A.; Baer, G.M. A rapid reproducible test for determining rabies

2 neutralizing antibodies. Bull. WHO,v. 48, n.5, p. 535-541, 1973.

3

4 Umehara, O.; De Lucca Neto, D.; Moro, E.; Bernardi, F.; Ito, F.H.; Rodrigues, C.A.

5 Rabies virus neutralizing antibody profile in cattle vaccinated with inactivated vaccine

6 adjuvanted with either aluminium hydroxide alone or combined with avridine. Arq.

7 Inst. Biol., v.69, n.1, p.23-28, 2002.

8

9

10

11

12

13

14

15

16 


\section{INSTRUCTIONS TO AUTHORS Journal of Animal Science (REVISED 2010)}

The Instructions for Authors to the Journal of Animal Science (JAS) is divided into 2 sections:

(I) Manuscript Preparation, which gives the Style and Form to be used by authors in the prepara. tion of manuscripts; and

(II) Policies and Procedures of JAS, which provides details concerning the mission of JAS, contact information, care and use of animals, the types of articles accepted by JAS, submitting manuscripts to JAS (including copyright policies), the review procedures and policies, and papers in press, author proofs, and publication charges.

\section{MANUSCRIPT PREPARATION (STYLE AND FORM)}

The most important thing you can do as you prepare your manuscript is to consult a recent issue of JAS in terms of the acceptable format for headings, title page, Abstract, Key words, Introduction, Materials and Methods, Results, Discussion (or combined Results and Discussion), Literature Cited, and tables and figures (including figure captions), which are described in more detail below. Failure to adhere to the style and form will result in immediate rejection of the manuscript.

General. Papers must be written in English and must use the American spelling and usage as well as standard scientific usage, as given in the following online resources:

- For general style and form, authors should follow that recommended in Scientific Style and Format. The CSE Manual for Authors, Editors, and Pub. lishers. 7th ed. Council of Science Editors, Reston, VA.

- For American English spelling and usage: Merriam-Webster OnLine (http://www.m-w.com/).

- For numbers usage, consult http://www.council scienceeditors.org/publications/ssf_numberstyle. cfm or the Policies Regarding Number Usage later in this document.

- For SI units, the following site (National Institute of Standards and Technology) provides a comprehensive guide: http://physics.nist.gov/cuu/Units/ index.html

- For capitalization and spelling of plants, consult the USDA Plants Web site (http://plants.usda. gov).
- For anatomical nomenclature, consult the current Nomina Anatomica Veterinaria (http://www. wava-amav.org/Downloads/nav_2005.pdf).

Manuscripts should be prepared double-spaced in Microsoft Word, with lines and pages numbered consecutively, using Times New Roman font at 12 points. Special characters (e.g., Greek and symbols) should be inserted using the symbols palette available in this font. Complex equations should be entered using MathType or an equation editor. Tables and figures should be placed in separate sections at the end of the manuscript (not placed in the text). Authors should prepare their manuscript in Microsoft Word and upload the manuscripts using the fewest files possible to facilitate the review and editing processes.

Manuscripts should contain the following sections (Appendices or On-Line Only Data Supplements, described below, are optional), in this order:

Title Page. The title page includes a running head (the first word only and any proper nouns capitalized and no more than 45 characters plus spaces); the title (only the first word and any proper nouns capitalized, as brief as possible, and including the species involved); names of authors (e.g., T. E. Smith; no title, positions, or degrees) and institutions, including the city, state or country (all with first letters capitalized), and ZIP or postal code. Affiliations are footnoted using the sym. bols *, $\dagger, \ddagger, \S, \#, \|, \tau$ and are placed below the author names. Footnotes on the first page (present address, and e-mail address of the corresponding author) are referenced by superscript numbers. Acknowledgments, including acknowledgements of grants, experiment sta. tion, or journal series number, are given as a footnote to the title. Authors who hold patents related to the research presented in the manuscript should include a statement in a footnote.

Abstract. The abstract consists of no more than 2,500 keystrokes (characters plus spaces) in one paragraph and summarizes the pertinent results (with statistical evidence; i.e., $P$-values) in a brief but understandable form, beginning with a clear statement of the objective and ending with the conclusions, with no references cited. Abbreviations in the abstract that are not Stan. dard JAS abbreviations must be defined at first use.

Key Words. List up to 6 key words or phrases in. cluding the species, variables tested, and the major response criteria. The first letter of each key word is low. ercase (unless a proper noun); key words are separated by commas and presented in alphabetical order; and no abbreviations should be used. Because major words 
in the title are not used for the subject index, which is published in the last issue of each volume of JAS, appropriate words from the title (or synonyms) should be listed as key words.

Introduction. The Introduction must not exceed 2,000 keystrokes (characters plus spaces) and briefly justifies the research, specifies the hypotheses to be tested, and gives the objective(s). Extensive discussion of relevant literature should be included in the Discus. sion.

Materials and Methods. A clear description or spe. cific original reference is required for all biological, analytical, and statistical procedures. All modifications of procedures must be explained. Diets, dates of experimental activities if appropriate, animals [breed, sex, age, body weight, and weighing conditions (i.e., with or without restriction of feed and water)], surgical techniques, measurements, and statistical models should be described clearly and fully. Appropriate statistical methods should be used, although the biology should be emphasized. Statistical methods commonly used in the animal sciences need not be described in detail, but adequate references should be provided. The statistical model, classes, blocks, and experimental unit must be designated. Any restrictions used in estimating parameters should be defined. Reference to a statistical package without reporting the sources of variation (classes) and other salient features of the analysis, such as covariance or orthogonal contrasts, is not sufficient. A statement of the results of the statistical analysis should justify the interpretations and conclusions. The experimental unit is the smallest unit to which an in. dividual treatment is imposed. Measurements on the same experimental unit over time also are not independent and should not be considered as independent experimental units. Reporting the actual $P$-value is preferred to the use of the terms significant and highly significant. Thus, the observed significance level (e.g., $P=0.027$ ) should be presented, thereby allowing the reader to decide what to reject. Other probability (alpha) levels may be discussed if properly qualified so that the reader is not misled. Provide a validation for assays [e.g., mean and CV for repeated analysis of a sample (both between and within-assay if available) and the sensitivity (minimum amount or concentration detectable)]. Also, provide a publication reference for the methodology used in kits. Centrifugal force should be provided in $\times g$, not $\mathrm{rpm}$, and duration and tem. perature of centrifugation must be included. Include volume of blood collected, container used, and amount of preservative or anticoagulant (e.g., heparin).

Results. The results are presented in the form of tables or figures when feasible. If data are discussed in the text but not presented in the tables or figures, specify "data not shown" in the text. The text should explain or elaborate on the tabular data, but numbers should not be repeated within the text. Sufficient data, all with some index of variation attached, should be presented to allow the reader to interpret the results of the experiment.

Discussion. The discussion should interpret the results clearly and concisely in terms of biological mechanisms and significance and also should integrate the research findings with the body of previously published literature to provide the reader with a broad base on which to accept or reject the hypotheses tested. A stand-alone Discussion section should not refer to any tables or figures, nor should it include $P$-values (unless citing a $P$-value from another work).

Results and Discussion. In JAS, authors have the option of combining the results and discussion into one section.

Literature Cited. To be listed in the Literature Cited section, papers must be published or accepted for publication ("in press"). Personal communications and unpublished data must not be included in the Literature Cited section. See the Literature Cited Guidelines later in this document.

Tables and Figures. Tables and figures must be prepared so they stand alone. Author-defined abbreviations should be defined in each table and figure. Manufacturer name and location should be provided for any proprietary product appearing in a table or figure.

Tables must be created using the table feature in MS Word (for instructions, see Guidelines for Creating Tables in Microsoft Word). Refer to a recent issue of JAS for examples of table construction. When possible, tables should be organized to fit across the page without running broadside. Each column must have a heading (e.g., Item, Ingredient, Trait, Fatty acid). Units should be separated from headings by a comma. Limit the data field to the minimum needed for meaningful comparison within the accuracy of the methods. In the body of the table, references to footnotes should be numerals. Each footnote should begin on a new line. To indicate significant differences among means within a row or column, superscript lowercase letters are used; the preferred statement in the footnotes is: "Within a row (or column), means without a common superscript differ $(P<0.05)$."

Figures should be placed at the end of the manuscript and should follow the Quality Guidelines for JAS Figures (http://jas.fass.org/misc/ifora.shtml). Each figure should be placed on a separate page (separated by section breaks) and identified by the manuscript number and figure number. Figure captions should be typed double spaced on a separate page. The use of color in figures should be avoided unless it is essen. tial to understanding the figure. There is an additional fee for color figures that are printed in the journal (see Color Charge Agreement at http://www.asas.org/jas/ color_charge.pdf).

Appendices. To provide readers with numerical examples or give extensive detail of analytical procedures, an appendix or appendices can be included. However, if the supplemental material is of interest only to a lim- 
ited number of JAS readers, it should not be included as an appendix. Instead, mention that supplemental information is available on request from the author; addresses for Web sites with appropriate supplemental information are acceptable. If extensive, the data may be included as an e-supplement to the manuscript (see Online-Only Data Supplements). Appendices should follow the Literature Cited section and be introduced by a major heading.

Online-Only Data Supplements. Authors can present material online that cannot physically be displayed in the print journal (e.g., Excel files, video), that might be cost-prohibitive (e.g., color figures), or that provides data sets too detailed for publication in print. A note will appear in the print version that more material can be found online. Material posted online only must go through the review process, and consequently should be in an format easily accessible by most reviewers and readers.

\section{Additional Usage Notes}

Numbers. See JAS Policies Regarding Number Us. age later in this document.

Abbreviations. Abbreviations in the text that are not Standard JAS abbreviations must be defined at first use. Authors should not use standard JAS abbreviations (e.g., $\mathrm{t}=$ metric ton and cannot be used as an abbreviation for temperature). Once defined, authoridentified abbreviations should always be used, except to begin a sentence. Author-identified abbreviations need to be redefined in the abstract, at first use in the body of the paper, in each table, and in each figure. See Standard JAS abbreviations later in this document, which includes standard abbreviations for physical units, units of time, statistical symbols and abbrevia. tions, and others. Standard JAS abbreviations should always be used except to begin a sentence or unless otherwise contraindicated (e.g., units of time should only be abbreviated when used with a number).

Gene and Protein Names. Because there is no universally accepted style for gene and protein names that applies to all species, the Journal of Animal Science asks the authors to assume the responsibility of using the convention appropriate for the particular spe. cies. Some general guidelines can be found in the CSE Manual for Authors, Editors, and Publishers (7th ed., 2006). For example, the gene that codes for the protein p53 is TP53 in humans and Trp53 in mice (note that, by convention, gene names are italicized; also note that protein names are generally not italicized).

Quantitative Trait Loci and DNA Markers. Papers that publish quantitative trait loci (QTL) or DNA marker association results for livestock are strongly encouraged to make their data available in an electron. ic form to one of the publicly available livestock QTL databases after the manuscript appears in publication [the date on which the paper is posted to the JAS.Pa. pers in Press Web site (http://jas.fass.org/papbyrecent. dtl) represents the official publication date]. Current QTL databases for livestock include, but may not be limited to, the Animal QTL database (http://www. animalgenome.org/QTLdb) and the Bovine QTL database (http://bovineqtl.tamu.edu/)

Commercial Products. The use of names of commercial products should be minimized. When a commercial product is used as part of an experiment, the manufacturer name, and location (city and state if in the United States; city and country otherwise) or a Web site ad. dress should be given parenthetically at first mention in text, tables, and figures. The generic name should be used subsequently. No ${ }^{\mathrm{TM}}$ or ${ }^{\circledR}$ symbols should be used.

General Usage.

- Note that "and/or" is not permitted; choose the more appropriate meaning or use " $\mathrm{x}$ or $\mathrm{y}$ or both."

- Report time using the 24-h system (e.g., $1410 \mathrm{~h}$ rather than $2: 10$ p.m.).

- Use italics to designate genus and species (Bos taurus) and botanical varieties (Medicago sativa var. Potomac). Designations for botanical culti. vars should be preceded by "cv." or enclosed in single quotes (e.g., Festuca arundinacea cv. Kentucky 31 or Festuca arundinacea 'Kentucky 31 ').

- Specify the basis (as-fed or dry matter) for dietary ingredient and chemical composition data listed in text or in tables. Similarly, specify the basis for tissue composition data (e.g., wet or dry basis).

- Calculations of efficiency should be expressed as output divided by input (i.e., gain:feed, not feed:gain). This avoids the spurious positive and negative infinity values when body weight gain is zero or negative. It also avoids the confusion associated with discussing an improvement as being a decrease.

- A diet is a feedstuff or a mixture of feedstuffs; a ration is the daily allotment of the diet.

- Restrict the use of "while" and "since" to meanings related to time. Appropriate substitutes include "and," "but," or "whereas" for "while" and "because" or "although" for "since."

- The words "Table" and "Figure" are capitalized and not abbreviated when used in the text to re. fer to a specific table or figure. Experiment and equation should be abbreviated to Exp. and Eq., respectively, when preceding a numeral.

- Avoid jargon unfamiliar to scientists from other disciplines. Do not use the term "head" to refer to an animal or group of animals. Instead, use animal, sow, ewe, steer, heifer, cattle, etc.

- Avoid bi- as a prefix because of its ambiguity; biweekly means twice per week and once every 2 wk.

- Breed and variety names should be capitalized (Landrace, Hereford). Trademarked or registered names should be capitalized, but no ${ }^{\mathrm{TM}}$ or ${ }^{(2)}$ symbols should be used. 


\section{POLICIES AND PROCEDURES OF JAS (return to Style and Form)}

The mission of the American Society of Animal Sci. ence (ASAS) is to foster communication and collabora. tion among individuals and organizations associated with animal science research, education, industry, or administration "To discover, disseminate, and apply knowledge for sustainable use of animals for food and other human needs." The Journal of Animal Science (JAS), which is published monthly by ASAS, accepts manuscripts presenting information for publication with this mission in mind. The editorial policies of JAS are established by the editor-in-chief, managing editor, division and associate editors, and editorial board, subject to review by the publications committee, board of directors, and the membership of ASAS. The views expressed in papers published in JAS rep. resent the opinions of the author(s) and do not nec. essarily reflect the official policy of the institution with which the author is affiliated, the ASAS, or the editor-in-chief. It is the responsibility of the authors to ensure the accuracy of collection, analysis, and in. terpretation of data in manuscripts and ultimately to guarantee the veracity of the contents of articles pub. lished in JAS.

The JAS is one of the most frequently cited, peerreviewed, agriculturally oriented research journals in the world, based on statistics published by ISI Inc. (Philadelphia, PA). Its high ranking in several ISI categories, including impact factor, attests to the quality standards maintained by the JAS editorial board, editors, and staff and by authors who submit manuscripts for publication.

\section{Contact Information}

For information on the scientific content of the jour. nal, contact the Editor-in-Chief, Dr. Steven A. Zinn, Department of Animal Science, University of Connecti. cut, Storrs, CT 06269-4040; phone: 860-486-0861; FAX: 860-486-4375; e-mail: steven.zinn@uconn.edu.

For other information or to submit a paper, contact Susan Pollock, Managing Editor and Director of Editorial and Production, Headquarters Office, American Society of Animal Science, 2441 Village Green Place, Champaign, IL 61822; telephone 217-356-7641; FAX 217-378-4083; journals@assochq.org.

For assistance with Manuscript Central, Manuscript Submission/Copyright forms, publication charge invoices, or offprint orders, contact Jeremy Holzner, Manuscript Central Coordinator and Editorial Assistant, Headquarters Office, 2441 Village Green Place, Champaign, IL 61822; FAX 217.378.4083; jeremyh@ assochq.org.

\section{Care and Use of Animals}

All manuscripts submitted to JAS must be accom. panied by a manuscript submission form certifying that any research that involves animals has followed established standards for the humane care and use of animals and must specify which standards were used. Only investigations that have followed high standards for the humane care and use of animals in research will be reported in JAS.

The manuscript must include a statement of institutional animal care and use committee (IACUC) (or equivalent) approval of all animal procedures. The IACUC statement should appear as the first item in the Materials and Methods. The manuscript should discuss anesthetics, analgesics, tranquilizers, and care taken to minimize pain and discomfort during preoperative, operative, and postoperative procedures. If research requires discomfort to the animals or stressful conditions, justification for these conditions must be evident in papers published in JAS.

\section{Types of Articles}

Articles published in JAS encompass a broad range of research topics in animal production and fundamental aspects of genetics, nutrition, physiology, and preparation and utilization of animal products. Articles typically report research with beef cattle, companion animals, goats, horses, pigs, and sheep; however, studies involving other farm animals, aquatic and wildlife species, and laboratory animal species that address fundamental questions related to the biology of livestock, companion animals, and other managed animals will be considered for publication. Manuscripts that report research on production issues in animals other than those constituting the main focus of the journal should be submitted to other journals.

The preceding paragraph is not meant to exclude manuscripts but, rather, is a clarification of the focus of the journal. If there are any questions concerning the appropriateness of a manuscript for the journal, please contact the editor-in-chief.

Research Articles. Results of work contained in manuscripts submitted to JAS must not have been published or submitted previously in a refereed sci. entific journal. Previous presentation at a scientific meeting or the use of data in field day reports or similar documents, including press publications or postings to personal or departmental Web sites, does not preclude the publication of such data in JAS. Articles simultaneously posted to Web sites and submitted to JAS should carry a disclaimer on the Web site that this version of the paper has not undergone JAS peerreview and is not to be considered the final published form of the article. If the article is published in JAS, the author should post the PDF (reprint) version of the article to the Web site so proper credit can be given to JAS as the publisher of the article. Because JAS holds the copyright to articles it publishes, posting altered JAS articles that are represented as exact duplicates of the published version constitutes copyright violation. 
Review Articles. The journal publishes board-invit. ed review articles each year; these reviews are iden. tified by the editor-in-chief in consultation with the editors. Occasionally proposals for review articles to be published in JAS may be solicited by division editors, after consultation with the editor-in-chief; the authors will be responsible for publication charges for these articles. Unsolicited review articles will not be consid. ered.

Special Topics. Papers will be considered for publication in this division that present Biographical or Historical Sketches, or that present viewpoints dealing with Contemporary Issues or Teaching in the animal sciences, or Perspectives that put a particular current topic into context in terms of its relationship or impor. tant to an entire area.

Biographies and Histories are part of the Special Topics Division but will be published only on the ASAS Web site (http://www.asas.org/pub_biohist.asp). The frequency of publication depends on the availability of the prepared sketches. See http://jas.fass.org/misc/ JAS_Bibliographical_Sketch_Instruct_10.pdf for more information.

Contemporary Issues include topics such as environ. mental concerns, legislative proposals, systems analy. sis, and others. Teaching papers may discuss innova. tive pedagogical methods, philosophy of education, or solutions to teaching problems in animal science. Al. though Contemporary Issues or Teaching papers do not have to include original data, whenever appropriate the stated assertions should be substantiated by references to established information from credible published sources.

Special Topics papers will be subject to peer review in a manner similar to other submissions. Because of the nature of these papers, their format may vary from that of standard scientific articles.

Technical Notes. A technical note is a vehicle to re. port a new method, technique, or procedure of interest to JAS readers. When possible, a technical note should include a comparison of results from the new method with those from previous methods, using appropriate statistical tests. The advantages and disadvantages of the new procedure should be discussed. When typeset, a technical note shall not exceed 6 pages (9 typed manuscript pages), including tables and figures. The words "Technical note" shall be the first words of the title of such manuscripts. The review process for a technical note will be the same as that for other manuscripts.

Letters to the Editor. Letters judged suitable for publication will be printed in a "Letters to the Editor" section of JAS. The purpose of this section is to provide a forum for scientific exchange relating to matters published in JAS. To be acceptable for publication, letters must adhere to the following guidelines: 1) Only letters that address matters of science and relate to informa. tion published in JAS will be considered. In general, letters should not exceed 5,000 characters plus spaces and should contain no more than 5 citations; 2) Letters should provide supporting evidence based on published data for the points made or must develop logical scientific hypotheses; letters based on conjecture or on unsubstantiated claims will not normally be published. No new data may be presented in the letters; 3) Letters will be considered by the editor-in-chief and if deemed appropriate for publication, the author(s) of original paper(s) will be invited to write a letter of response. Normally both letters will be published together; and 4) All letters will be subject to acceptance and editing by the editorin-chief and editing by the technical editor.

\section{SUBMISSION OF MANUSCRIPTS}

Manuscripts should be submitted electronically at http://me.manuscriptcentral.com/jas. Authors who have questions about using the electronic manuscript submission system should contact Jeremy Holzner, Manuscript Central coordinator and editorial assistant at: jeremyh@assochq.org. Authors who are unable to submit electronically should contact Jeremy Holzner (jeremyh@assochq.org) for assistance; include your manuscript as an attachment (saved as a Microsoft Word file). Staff at ASAS headquarters will post manuscripts by proxy, but authors should be aware that delays might occur in the review process.

\section{Copyright Agreement}

Authors shall complete the Manuscript Submission and Copyright Release form for each new manuscript submission; faxed copies are acceptable. The form is available online at http://jas.fass.org/misc/JAS. Copyright new.pdf. The copyright agreement is includ. edin the Manuscript Submission and Copyright Release form and must be completed by all authors before publication can proceed. The corresponding author is responsible for obtaining the signatures of coauthors. Persons unable to sign copyright agreements, such as federal employees, must indicate the reason for exemption on the form. The copyright to material published in JAS is held by ASAS. Persons who wish to reproduce material in JAS must request written permission to reprint copyrighted information from the managing editor. Likewise, authors of JAS manuscripts who include material (usually tables or figures) taken from other copyrighted sources must secure permission from the copyright holders and provide evidence of this permission at the time the manuscript is submitted to JAS for review. Tables or figures reproduced from the work of others must include an acknowledgment of the original source in a footnote or legend.

\section{REVIEW OF MANUSCRIPTS}

General Procedures. The suitability of all manuscripts for publication in JAS is judged by the review. ers and associate editors, division editors, and the editor-in-chief. All communications regarding a submitted manuscript should maintain confidentiality. Associate 
editors handle correspondence with the author and promptly advise the division editor whether a manu. script should be rejected or accepted. The division editor's decision to reject or accept is based on the associate editor's recommendation and his or her own review of the manuscript. The division editor forwards document files for accepted manuscripts to the editor-in-chief for further review and editing, after which the editor-inchief forwards the document file(s) to the technical edi. tors. Note that most manuscripts that are eventually published are first returned by the associate editor to the author for revision, and in addition, the division editor may ask for changes before acceptance. The editor-in-chief is the final arbiter regarding acceptance or rejection of manuscripts submitted for publication.

Rejections. There are 3 main grounds for rejection of manuscripts. First, manuscripts that are not written clearly, concisely, and coherently or that do not con. form to JAS style and form guidelines will be rejected without review. Nonnative English authors are urged to have their paper reviewed by a native English writ. er. Second, the substance of the manuscript may not meet JAS standards: the work may be incomplete, the evidence may not support the conclusions, the experimental approach may be poorly conceived, or the work may repeat established fact or represent no advance of existing knowledge. Third, although the work may be sound and the results valid, the paper may be better suited for publication elsewhere.

Appeals. If a manuscript is rejected, as a first course of action the author may discuss the matter with the associate editor or division editor responsible for the manuscript. Decisions must be appealed to the editor. in-chief if the author(s) believe(s) that the judgment was erroneous or unfair. A letter presenting the reasons for the appeal should be sent to the editor-in-chief. The editor-in-chief will review the author's reasons, as well as all materials related to the manuscript and, after consulting with the editors who reviewed the manuscript, will render a decision whether to accept or deny the appeal. A rejected manuscript may be resubmitted for publication in another division of JAS only if this course of action has been specifically recommend. ed by the associate editor or division editor originally assigned to the manuscript and the transfer has been approved by the editor-in-chief.

Revisions. Most manuscripts that are eventually published are returned to the author(s) for revision. Normally, the revised manuscript must be returned to the associate editor via JAS Manuscript Central with. in $6 \mathrm{wk}$ from the date of receipt by the author or the manuscript will be withdrawn. Extenuating circum. stances must be communicated to the technical editing staff, who will consult with the editor-in-chief before granting an extension. A Revision Checklist (http://jas. fass.org/misc/JAS_Revison_checklist.pdf) is sent with requests for revision to assist the authors.

\section{PAPERS IN PRESS, AUTHOR PROOFS, AND PUBLICATION CHARGES}

Papers in Press. To facilitate earlier dissemination, accepted manuscripts will be assigned a digital object identifier (DOI) and posted to the JAS Papers in Press site (http://jas.fass.org/papbyrecent.dtl) in the form in which they are accepted; because this does not repre. sent the final, published form of the manuscript, the authors bear the primary responsibility for the content of manuscripts posted to the publish-ahead-of-print site.

Author Proofs. Accepted manuscripts are forwarded by the editor-in-chief to the editorial office for technical editing and typesetting. At this point, the technical editor may contact the authors for missing information or figure revisions. The manuscript is then typeset, figures reproduced, and author proofs prepared. Correspondence concerning the accepted manuscript should be directed to the technical editor.

Proofs of all manuscripts will be provided to the cor. responding author and should be read carefully and checked against the typed manuscript; accuracy of the galley proof is the author's responsibility. Corrections may be returned by fax, mail, or e-mail. For faxed or mailed corrections, changes to the proof should be made neatly and clearly in the margins of the proof. If extensive correction is required, changes should be provided on a separate sheet of paper with a symbol indicating location on the proof. Changes sent by e-mail to the technical editor must indicate page, column, and line numbers for each correction to be made on the proof. Editor queries should be answered on the galley proofs; failure to do so may delay publication. Excessive au. thor changes made at the proof stage may result in a $\$ 250$ surcharge.

Publication Charges and Reprints. The journal has 2 options available for publication: open access (OA) and conventional page charges. For the OA option, authors will pay the OA fee when proofs are returned to the editorial office so that their paper will become freely available upon publication in an online issue. Charges for OA publication are $\$ 2,500$ per article, if at least one author is a current professional member of ASAS; the charge is $\$ 3,250$ when no author is an ASAS member. For conventional publication, the charge is $\$ 85$ per printed page in JAS if at least one author is an ASAS member; the page charge is $\$ 170$ when no author is a member of ASAS. Reprints may be ordered at an additional charge. When the galley proof is sent, the author is asked to complete a reprint order form requesting the number of reprints desired and the name of the institution, agency, or individual respon. sible for publication charges. Authors who submit ar. ticles containing color illustrations are responsible for paying the additional charge for color printing, includ. ing the printing of any reprints they order. 
Instructions to Authors of Journal of Animal Science

\section{STANDARD JAS ABBREVIATIONS (return to Style and Form)}

The following abbreviations should be used without definition in JAS; plural abbreviations do not require a final " $\mathrm{s}$ ". Use of 3-letter abbreviations for amino acids (e.g., Ala) is acceptable in JAS. For chemical units and abbreviations, refer to the ACS Style Guide (published by the American Chemical Society, Washington, DC).

\section{Physical units}

\begin{tabular}{ll}
\hline \hline Item & Unit \\
\hline $\mathrm{Bq}$ & becquerel \\
${ }^{\circ} \mathrm{C}$ & degree Celsius \\
$\mathrm{cal}$ & calorie \\
$\mathrm{Ci}$ & curie \\
$\mathrm{cM}$ & centimorgan (spell out morgan if used \\
& without a prefix) \\
$\mathrm{Da}$ & dalton \\
$\mathrm{Eq}$ & equivalent (only can be used with a prefix) \\
$\mathrm{g}$ & gram \\
$\mathrm{ha}$ & hectare \\
$\mathrm{Hz}$ & hertz \\
$\mathrm{IU}$ & international unit \\
$\mathrm{J}$ & joule \\
$\mathrm{L}$ & liter \\
$\mathrm{lx}$ & lux \\
$\mathrm{m}$ & meter \\
$M$ & molar (concentration; preferred over mol/L) \\
$\mathrm{mol}$ & mole \\
$\mathrm{N}$ & normal (concentration) \\
$\mathrm{Pa}$ & pascal \\
$\mathrm{rpm}$ & revolutions/minute (not to be used to \\
& indicate centrifugal force) \\
$\mathrm{t}$ & metric ton (1,000 kg) \\
$\mathrm{V}$ & volt \\
$\mathrm{W}$ & watt \\
\hline
\end{tabular}

\section{Units of time}

\begin{tabular}{ll}
\hline \hline Item & Unit \\
\hline $\mathrm{s}$ & second(s) \\
min & minute(s) \\
$\mathrm{h}$ & hour(s) \\
$\mathrm{d}$ & day(s) \\
wk & week(s) \\
mo & month(s) \\
$\mathrm{yr}$ & year(s) \\
\hline
\end{tabular}

\section{Statistical symbols and abbreviations}

\begin{tabular}{ll}
\hline \hline Item & Term \\
\hline ANOVA & $\begin{array}{l}\text { analysis of variance } \\
\text { coefficient of variation }\end{array}$
\end{tabular}

df degree(s) of freedom (spell out if used without units)

F $\quad F$-distribution (variance ratio)

LSD least significant difference

n sample size (used parenthetically or in footnotes)

$P \quad$ probability

$\mathrm{r} \quad$ simple correlation coefficient

$\mathrm{r}^{2} \quad$ simple coefficient of determination

$\mathrm{R} \quad$ multiple correlation coefficient

$\mathrm{R}^{2} \quad$ multiple coefficient of determination

$\mathrm{s}^{2} \quad$ variance (sample)

SD standard deviation (sample)

SE standard error

SED standard error of the differences of means

SEM standard error of the mean

$t \quad t$ - (or Student) distribution

$\alpha \quad$ probability of Type I error

$\beta \quad$ probability of Type II error

$\mu \quad$ mean (population)

$\sigma \quad$ standard deviation (population)

$\sigma^{2} \quad$ variance (population)

$\chi^{2} \quad$ chi-squared distribution

\section{Others}

\begin{tabular}{|c|c|}
\hline Item & Term \\
\hline AA & amino acid(s) \\
\hline ACTH & adrenocorticotropic hormone \\
\hline $\mathrm{ADF}$ & $\begin{array}{l}\text { acid detergent fiber (assumed sequential } \\
\text { unless designated otherwise) }\end{array}$ \\
\hline ADFI & $\begin{array}{l}\text { average daily feed intake (not to be } \\
\text { confused with DMI) }\end{array}$ \\
\hline $\mathrm{ADG}$ & average daily gain \\
\hline $\mathrm{ADIN}$ & acid detergent insoluble nitrogen \\
\hline $\mathrm{ADL}$ & acid detergent lignin \\
\hline $\mathrm{ADP}$ & adenosine diphosphate \\
\hline AI & artificial insemination \\
\hline AIA & acid insoluble ash \\
\hline ARS & Agricultural Research Service \\
\hline ATP & adenosine triphosphate \\
\hline avg & $\begin{array}{l}\text { average (use only in tables, not in the } \\
\text { text) }\end{array}$ \\
\hline $\mathrm{BCS}$ & body condition score \\
\hline BLUP & best linear unbiased prediction \\
\hline bp & base pair \\
\hline BSA & bovine serum albumin \\
\hline BTA & Bos taurus chromosome \\
\hline BW & body weight (used for live weight) \\
\hline cDNA & complementary deoxyribonucleic acid \\
\hline C/EBP & CAAT-enhancer binding protein \\
\hline cfu & colony-forming unit \\
\hline CIE & International Commission on Illumination \\
\hline CLA & conjugated linoleic acid \\
\hline $\mathrm{CoA}$ & coenzyme A \\
\hline Co-EDTA & cobalt ethylenediaminetetraacetate \\
\hline $\mathrm{CP}$ & crude protein $(\mathrm{N} \times 6.25)$ \\
\hline
\end{tabular}


8

DE digestible energy

$\mathrm{DEAE}$ (dimethylamino)ethyl (as in DEAE. cellulose)

DFD dark, firm, and dry (meat)

DM dry matter

DMI dry matter intake

DNA deoxyribonucleic acid

EBV estimated breeding value

eCG

EDTA

EFA

EIA

ELISA

EPD

Eq.

Exp.

FFA

FSH

$g$

GE

G:F

GLC

GLM

$\mathrm{GnRH}$

GH

GHRH

hCG

$\mathrm{HCW}$

HEPES

HPLC

i.d.

$\mathrm{Ig}$

IGF

IGFBP

IL

IVDMI

kb

$\mathrm{KPH}$

L

$\mathrm{LD}_{50}$

$\mathrm{LH}$

LHRH

LM

ME

MP

mRNA

MUFA

NAD

$\mathrm{NADH}$
Instructions to Authors of Journal of Animal Science

\begin{tabular}{|c|c|}
\hline NDF & neutral detergent fiber \\
\hline NDIN & neutral detergent insoluble nitrogen \\
\hline $\mathrm{NE}$ & net energy \\
\hline $\mathrm{NE}_{\mathrm{g}}$ & net energy for gain \\
\hline $\mathrm{NE}_{1}$ & net energy for lactation \\
\hline $\mathrm{NE}_{\mathrm{m}}$ & net energy for maintenance \\
\hline NEFA & nonesterified fatty acid \\
\hline No. & $\begin{array}{l}\text { number (use only in tables, not in the } \\
\text { text) }\end{array}$ \\
\hline NPN & nonprotein nitrogen \\
\hline $\mathrm{NRC}$ & National Research Council \\
\hline o.d. & outside diameter \\
\hline $\mathrm{OM}$ & organic matter \\
\hline PAGE & polyacrylamide gel electrophoresis \\
\hline PBS & phosphate-buffered saline \\
\hline PCR & polymerase chain reaction \\
\hline PG & prostaglandin \\
\hline PMSG & pregnant mare's serum gonadotropin \\
\hline PPAR & $\begin{array}{l}\text { peroxisome proliferator-activated } \\
\text { receptor }\end{array}$ \\
\hline PSE & pale, soft, and exudative (meat) \\
\hline PUFA & polyunsaturated fatty acid(s) \\
\hline QTL & quantitative trait locus (loci) \\
\hline RDP & ruminally degradable protein \\
\hline REML & restricted maximal likelihood \\
\hline RFLP & $\begin{array}{l}\text { restriction fragment length } \\
\text { polymorphism }\end{array}$ \\
\hline RIA & radioimmunoassay \\
\hline RNA & ribonucleic acid \\
\hline RQ & respiratory quotient \\
\hline RUP & ruminally undegradable protein \\
\hline rRNA & ribosomal ribonucleic acid \\
\hline SAS & Statistical Analysis System \\
\hline SDS & sodium dodecyl sulfate \\
\hline SFA & saturated fatty acid \\
\hline SNP & single nucleotide polymorphism \\
\hline ssp. & subspecies \\
\hline ST & somatotropin \\
\hline spp. & species \\
\hline SSC & Sus scrofa chromosome \\
\hline TDN & total digestible nutrients \\
\hline TLC & thin layer chromatography \\
\hline Tris & tris(hydroxymethyl)aminomethane \\
\hline tRNA & transfer ribonucleic acid \\
\hline TSAA & total sulfur amino acids \\
\hline USDA & US Department of Agriculture \\
\hline UV & ultraviolet \\
\hline VFA & volatile fatty acid(s) \\
\hline vol & volume \\
\hline $\mathrm{vol} / \mathrm{vol}$ & $\begin{array}{l}\text { volume/volume (used only in } \\
\text { parentheses) }\end{array}$ \\
\hline vs. & versus \\
\hline wt & $\begin{array}{l}\text { weight (use only in tables, not in the } \\
\text { text) }\end{array}$ \\
\hline wt/vol & weight/volume (used only in parentheses) \\
\hline wt/wt & weight/weight (used only in parentheses) \\
\hline
\end{tabular}




\section{LITERATURE CITED GUIDELINES FOR JOURNAL OF ANIMAL SCIENCE \\ (return to Literature Cited in Style and Form)}

Citations in the Text. In the body of the manuscript, refer to authors as follows: Smith and Jones (1992) or Smith and Jones $(1990,1992)$. If the sentence struc. ture requires that the authors' names be included in parentheses, the proper format is (Smith and Jones, 1982; Jones, 1988a,b; Jones et al., 1993). When there are more than 2 authors of an article, the first author's name is followed by the abbreviation et al. More than 1 article listed in the same sentence or parentheses must be in chronological order first and alphabetical order for 2 publications in the same year. Published articles, and not abstracts, should be cited whenever possible; if the work was originally described in an abstract, the author(s) should use a literature search to determine if the work has been published as a peer-reviewed ar. ticle.

Work that has not been accepted for publication shall be listed in the text as "J. E. Jones (institution, city, and state or country, personal communication)." The author's own unpublished work should be listed in the text as "(J. Smith, unpublished data)." Personal communica. tions and unpublished data must not be included in the Literature Cited section.

Literature Cited Section. To be listed in the Liter. ature Cited section, papers must be published or accepted for publication ("in press"). In the Literature Cited section, references are listed alphabetically by the author(s)' last name(s), and then chronologically. The year of publication follows the authors' names. As with text citations, 2 or more publications by the same author or set of authors in the same year shall be differentiated by adding lowercase letters after the date. All authors' names must appear in the Literature Cited section. Journals shall be abbreviated according to the conventional ISO abbreviations used by PubMed (http://www.ncbi.nlm.nih.gov/entrez/query.fcgi). A list of standard abbreviations for frequently cited journals and abbreviations used in citations is available at http://www.asas.org/jas/journal_abbrevs.pdf One-word titles must be spelled out. Inclusive page numbers must be provided.

Sample references are as follows:

1. Books and articles within edited books:

AOAC. 1990. Official Methods of Analysis. 15th ed. Assoc. Off. Anal. Chem., Arlington, VA.

NRC. 1989. Nutrient Requirements of Dairy Cattle. 6th rev. ed. Natl. Acad. Press, Washington, DC,

Robinson, P. H., E. K. Okine, and J. J. Kennelly. 1992. Measurement of protein digestion in ruminants. Page 121 in Modern Methods in Protein Nutrition and Metabolism. S. Nissen, ed. Academic Press, San Diego, CA.

2. Handbooks, technical bulletins, theses, and dissertations
Goering, H. K., and P. J. Van Soest. 1970. Forage Fiber Analyses (Apparatus, Reagents, Procedures, and Some Applications). Agric. Handbook No. 379. ARS-USDA, Washington, DC.

Sigma. 1984. Total hemoglobin: Quantitative, colorimetric determination in whole blood at 530-550 nm. Tech. Bull. No. 525. rev. ed. Sigma Chemical, St. Louis, MO.

Ward, J. D. 1995. Effects of copper deficiency on performance and immune function of cattle. PhD Diss. North Carolina State Univ., Raleigh.

3. Journal articles and abstracts

Cleale, R. M., IV, R. A. Britton, T. J. Klopfenstein, M. L. Bauer, D. L. Harmon, and L. D. Satterlee. 1987a. Induced non-enzymatic browning of soybean meal. II. Ruminal escape and net portal absorption of soybean protein treated with xylose. J. Anim. Sci. 65:1319-1326.

Hall, J. B., R. B. Staigmiller, R. E. Short, R. A. Bellows, S. E. Bartlett, and D. A. Phelps. 1993. Body composition at puberty in beef heifers as influenced by nutrition and breed. J. Anim. Sci. 71(Suppl. 1):205. (Abstr.)

4. Conference proceedings

NMC. 1995. Summary of peer-reviewed publications on efficacy of premilking and postmilking teat disinfections published since 1980. Pages 82-92 in Natl. Mastitis Counc. Reg. Meet. Proc., Harrisburg, PA. Natl. Mastitis Counc., Arlington, VA.

Talmant, A., X. Fernandez, P. Sellier, and G. Monin. 1989. Glycolytic potential in longissimus dorsi muscle of Large White pigs as measured after in vivo sampling. Page 1129 in Proc. 35th Int. Congr. Meat Sci. Technol., Copenhagen, Denmark.

Van der Werf, J. H. J.1990. A note on the use of conditional models to estimate additive genetic variance in selected populations. Proc. 4th World Congr. Genet. Appl. Livest. Prod., Edinburgh, Scotland XIII:476-479.

\section{Electronic Publications}

FDA. 2001. Effect of the use of antimicrobials in food-producing animals on pathogen load: Systematic review of the published literature, http://www.fda.gov/cvm/antimicrobial/PathRpt.PDF Accessed Dec. 14, 2001.

Huntington, G. B., D. L. Harmon, N. B. Kristensen, K. C. Hanson, and J. W. Spears. 2006. Effects of a slow-release urea source on absorption of ammonia and endogenous production of urea by cattle. Anim. Feed Sci. Technol, doi:10.1016/j.anifeedsci. 2006.01 .012

Le Neindre, P., C. Terlouw, X. Boivin, A. Boissy, and J. Lensink. 2001. Behavioral research and its application to livestock transport and policy: A European perspective. J. Anim. Sci. 79(E-Suppl.) http://www.asas.org/jas/jas0905.pdf Accessed Oct. 7, 2001.

\section{POLICIES REGARDING NUMBER USAGE FOR JOURNAL OF ANIMAL SCIENCE (return to Style and Form)}

In 2006, JAS adopted the proposed changes for num. ber style by the Council of Science Editors for the seventh edition of their Scientific Style and Format. The greatest change is more widespread use of numerals for single-digit numbers. A full description of the new number style is available online (http://www.council scienceeditors.org/publications/ssf_numberstyle.cfm).

A summary of the CSE number style policies is as follows: 
- All cardinal numbers are written as numerals except when they begin a sentence or appear in a title, when 2 numerals are adjacent in a sentence (spell out the number most easily expressed in words; e.g., two $10 . \mathrm{kg}$ samples), or when a number is used as a figure of speech.

- Numbers less than 1 are written with a preceding (leading) zero (e.g., 0.75).

- A comma separator is used in numbers greater than 999.

- Numerals should be used to designate ratios and multiplication factors (e.g., 2:1, 3-fold increase).

- If a number is spelled out at the beginning of a sentence, its associated unit is also spelled out (e.g., Ten milliliters of fluid . .., not Ten $\mathrm{mL}$ of fluid ....).

- Units of measurement not preceded by a number should be spelled out rather than abbreviated (e.g., lysine content was measured in milligrams per kilogram of diet) unless used parenthetically.

- Single-digit ordinals are spelled out (i.e., first through ninth); larger ordinals are expressed in numeric form. Single-digit ordinals may be ex. pressed numerically when they form part of a series (e.g., 1st, 3rd, 10th, 20th, not first, third, 10th, 20th).

General number usage policies of JAS are as follows:

- Measures must be presented in the metric system (SI or Système International d'Unités; see: http://
physics.nist.gov/cuu/Units/introduction.html, or http://physics.nist.gov/Pubs/SP330/sp330.pdf

- When a term must be expressed in nonmetric units for clarity (e.g., bushel weight), give such values in parentheses after the metric value.

- Use "to" instead of a hyphen to indicate a numerical range in text.

- Avoid the use of multiplying factors (e.g., $\times 10^{6}$ ) in table columns or rows, or in figure axis labels because of the uncertainty whether the data are to be, or already have been, converted by the factor.

- Avoid ambiguity by stating units (e.g., numbers of spermatozoa, millions $/ \mathrm{mL}$ ).

- Do not use more than one slant line (for "per") in a single expression (e.g., use $5 \mathrm{mg} /(\mathrm{g} \cdot \mathrm{d}$ ) or $5 \mathrm{mg}$. $\mathrm{g}^{-1} \cdot \mathrm{d}^{-1}$ instead of $\left.5 \mathrm{mg} / \mathrm{g} / \mathrm{d}\right)$. Mathematically, "per" implies division; when 2 "per" occur consecutively, it is unclear precisely what is being divided by what.

- Dietary energy may be expressed in calories or in joules; the standard SI unit for energy is the joule.

- Hyphenate units of measure used as preceding adjectives (e.g., 5-kg sample). Hyphens are not used with percent or degree signs.

- Insert spaces around all signs (except slant lines) of operation $(=,-,+, \times,>$, or $<$, etc.) when these signs occur between 2 values.

- Convert "mg \%" to other units, such as $\mathrm{mg} / \mathrm{L}$ or $\mathrm{mg} / \mathrm{mL}$; use "mol/100 mol" rather than "molar percent." 


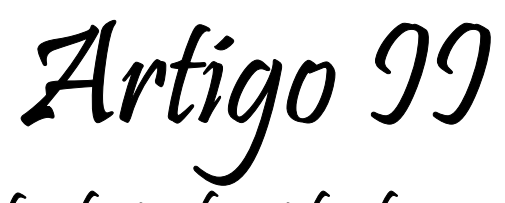

Vaccinal immune response and interference of colostral antibodies in calues vaccinated at 2,4 and 6 month of age born from revaccinated females 
Vaccinal immune response and interference of colostral antibodies in calves vaccinated at 2, 4 and 6 month of age born from revaccinated females

7 The placenta of ruminants is syndesmochorial preventing the passage of 8 immunoglobulins molecules, so the newborns are entirely dependent on antibodies 9 received through the colostrum. They rely exclusively on passive immunity absorbed 10 from maternal colostrum for their protection against infection during the first weeks of 11 their life. The objective of this work was to evaluate the interference of colostral 12 antibodies and the humoral immune response of calves vaccinated against rabies at 2, 4 13 and 6 month of age, born from revaccinated females. Females revaccinated against 14 rabies at the final third of pregnancy were studied. Forty hours after parturition blood from dams and offsprings were collected and the antirabies neutralizing sera antibodies titers analyzed by RFFIT. The conventionally defined FAVN level of $0.5 \mathrm{IU} / \mathrm{ml}$ was considered as a cut-off for rabies protection. Antibodies transferred by colostrum with similar titers were observed in all calves studied 48 hours after birth. Seraneutralizing anti-rabies titers above $0,5 \mathrm{UI} / \mathrm{mL}$ remained until the $5^{\text {th }}$ month in calves vaccinated to 2 months while decreased after the 3 months in the other groups representing a period of

21 lack of protection higher than 2 months vaccinated group. None of the groups presented satisfatory serological response after the first vaccination, but all have appropriate response after revaccination. The study showed that anti-rabies vaccination can be recommended in calves two months of age regardless of maternal vaccination status followed by re-vaccination 30 days after, and when they reach 12 months of life.

1- UNESP- School of Veterinary Medicine and Animal Science- Departament of Veterinary Hygiene and Public Health- BotucatuSP, Brasil

2- Zoonosis Control Center - Rabies Laboratory - São Paulo-SP, Brasil

3- UNESP- School of Veterinary Medicine and Animal Science- *email:jane@fmvz.unesp.br 


\section{Introduction}

According to Panamerican Health Organization [22], 2797 cases of rabies in

4 cattle were reported in 2004 in the countries of the Americas, 87\% more cases than in

5 2002. Of these, 2591 (92.6\%) occurred in Latin America; 130 (4.6\%) in North America

6 and 76 in Caribbean and Guatemala. In Latin America, Brazil had 60.6\% of cases,

7 followed by $13 \%$ in Mexico and $8 \%$ in the Andes.

There's no predisposition of race, sex or age, but a greater prevalence of the

9 disease can be observed in young animals [16]. The occurrence of numerous cases in

10 calves under one year of age may be related mainly to immunity in this age, since this

11 phase occurs the lacking of colostral immunity and the animals have not been

12 vaccinated against rabies, or if received the first vaccine, in most cases, not received the

13 vaccinal booster $[17,20]$.

In a study by Lima et al. (2005), in 25 cases of bovine rabies diagnosed in a veterinary hospital of Federal University of Paraíba, Campina Grande, higher prevalence was observed in young animals, with less than two years of age. The authors correlated this to the lower immunity of these animals that were not re-vaccinated after 30 days of the first vaccination, performed to three and four months of age. The same situation was observed in Mato Grosso do Sul where an increased prevalence in young animals was also noted $[16,20]$. 
Albas et al. (2004), in Presidente Prudente-SP studing the humoral immune

2 response have examined ten different lots of antirabies vaccine in 139 vaccinated cattle.

3 The results showed significant differences in the different types of vaccines. Three of 4 them presented 73, 3\% 52,9\% and $80 \%$ percentage of animals not reagents, 5 demonstrating vaccinal failures.

6 In a study with 35 cattle, Albas et al., (1998) reported that booster doses of 7 vaccination induced higher titers of antibodies. The authors observed that $19 \%$ of who

8 received a dose of booster 30 days after vaccination maintained antirabies antibodies

9 titers greater or equal to $0,5 \mathrm{UI} / \mathrm{mL}$ after 360 days, as opposed to the group that did not 10 receive the booster, where only $4,7 \%$ presented titer equal to $0,5 \mathrm{UI} / \mathrm{mL} 270$ days after.

This same group of researchers (Albas et al., 2006), following this same subject compared three groups of animals ( $\mathrm{a}, \mathrm{b}$ and $\mathrm{c}$ ) using three alternative protocols of

13 immunization with rabies inactivated vaccine. The Group A received a single dose of 14 vaccine, the group B received a booster after 30 days and group C a booster 30 and 180 15 days after the first immunization. The results demonstrated that Group C presented 16 higher and more persistent antirabies antibodies titers compared to the two other groups.

Some researchers also reported similar results confirming that the immune response induced by only one vaccine dose does not induce high antibodies titers

$19[28,32,27,23]$. However, where doses of booster are done, the seraneutralizing 20 antibodies titers become significantly higher [1,21].

21 Compared with active immunity described above, passive immunity transferred 22 through colostrum to calves after birth, has a limited duration, having been verified that 23 it is detected for a relatively short period, while immunity actively induced by 
1 vaccination is in many cases more lasting. The newborn ungulates have initial

2 protection achieved by passive transfer of immunoglobulin (Ig) from mother to newborn

3 [24]. The transfer of the maternal antibodies to fetus is determined by the structure of

4 the placenta. The placenta of ruminants is syndesmocorial. This type of placenta

5 prevents the passage of Ig molecules to the fetus and newborn are so dependent on

6 antibodies received through colostrum $[8,31,11]$.

7 In cattle, it is essential that the calves ingest the colostrum until 24 hours post

8 birth, once the concentration of intestinal proteolityc enzymes is very low in the first

9 hours after birth and the immunoglobulins obtained through ingestion of colostrum

10 reach the small intestine where they are absorbed reaching the epithelial cells by

11 pinocytosis, passing completely inside the intestinal capillaries reaching the circulatory

12 system resulting in massive Ig absorption [8].

13 Failure of colostral appropriate antibodies transfer can occur due to some factors

14 such as insufficient quantity or poor quality of colostrum production, bulk of ingested

15 colostrum, Ig concentration in colostrum, age at first pregnancy of the cow and weight

16 of calf at birth $[9,11]$.

17 The acquisition of passive immunity in neonates is dependent on the ingestion

18 and absorption of appropriate quantities of Ig from colostrum, essential to provide

19 protection to at least the first two to four weeks of life [25,9].

20 One of the biggest challenges in the development of an active immune response

21 in calves has been assigned to maternal immunity to interference. When the vaccine in

22 large animals is delineated, it should be remarked that there is a large variability in the 
1 persistence of maternal antibodies. One important factor in maternal antibodies

2 persistence, is the level of maternal antibodies in serum [19].

In young animals, in anti-rabies vaccination, as well as in any other vaccine, the

4 presence of colostral antibodies can inhibit the establishment of active immunity [26].

5 This may be due in part to a negative feedback, through which the combination of

6 specific Ig with the cristaloids fragment receivers of B-cell immunoglobulin, blocks the

7 activity of B-cell receptor and thereby inhibits the further production of more antibodies

8 of the same specificity. The maternal antibody passively transferred can thus prevent

9 successful vaccination in young animals. This period can take months, depending on the

10 amount of Ig transferred to the neonate and half life of Ig [31].

11 In a study by Bunn (1988), interference of vaccination in calves with the SAD

12 vaccine also was assigned the colostral antibodies. The author noted, however, that the

13 titer of maternal antibodies measured in younger calves was extremely lower and not

14 correlated with the titer of the mother after the birth. Thus considered the possibility of a

15 inappropriate immune response in young animals, due to insufficient immune response

16 due to colostral antibodies interference

Research conducted in Bolivia by Arnold et al., (1973), assessed the possibility

18 of colostral antibodies interference against rabies in calves born from revaccinated

19 mothers six months before the parturition. The calves were vaccinated with a single

20 dose of the same vaccine to four, five, six and seven months of age. The media of

21 antibodies titers between the four groups was 5.0, 7.7, 15.8 and $31.9 \mathrm{UI} / \mathrm{mL}$ being

22 detected maternal antibodies until 6 months of age. The results indicated interference on

23 the response of vaccination in young calves young recommending re-vaccination to 12

24 months of life. 
Previous researchs using primevacinated cows not subject to booster after

2 vaccination, interference in vaccination was observed in vaccinated calves two and four

3 months old, evidenced by fewer animals that presented serum convertion 15 days after

4 anti-rabies vaccination. After vaccinal booter, however, the animals responded to the

5 vaccine in a similar way. Additionally, in this experiment, the authors observed absence

6 of seroconversion in nine (35,7\%) from 30 cows, characterizing possible vaccinal

7 failures and suggesting that need of booster vaccinal [14].

Anti-rabies vaccination has been indicated to three months of age with booster

930 days after in the prophylaxis for rabies. Up to this age, vaccinated calves born from

10 vaccinated mothers has colostral antibodies in satisfactory protection levels. When born

11 from non vaccinated mothers the anti-rabies vaccine is indicated at birth because

12 although they do have not a immune system completely competent early vaccination

13 will enable memory cells, collaborating with a future immune response [15].

Soulebot (1978), consider that, to be effective, vaccination against rabies should not be indicated before the age of four months in calves born vaccinated mothers.

16 According to the same author, calves must have nine months of age before being vaccinated. When vaccinated between four and six months, booster is advisable before reaching one year of age.

The schedule of administration of many vaccines involves the estimation of the time that the maternal antibodies level is low enough to induce an immune response and provide active immunity in calves for a particular antigen vaccine, [13]. 
1 vaccinated and revaccinated mothers the aim of this work was to evaluate the vaccinal

2 response in calves vaccinated with two, four and six months of age born from

3 primevaccinated and revaccinated females considering also the importance of

4 revaccination in colostral protection and vaccinal interference which would reduce the

5 success of control programs.

6

7 Material and Methods

8

Pregnant females previously vaccinated against rabies were submitted to

10 antirabies vaccine at the final third of pregnancy. Forty hours after parturition blood

11 from dams and offsprings were collected and the anti-rabies neutralizing sera titers

12 analyzed. Four groups were constituted composed of ten calves being a group of non-

13 vaccinated, and three groups that have been vaccinated, respectively, to two, four and

14 six months of age and revaccinated ( booster) after 30 days. The animals were evaluated

15 serologically 15 days and monthly after vaccination until completed one year of age.

16 Sera of all animals were tested for rabies virus neutralizing antibody by RFFIT [29,12].

17 The conventionally defined FAVN level of $0.5 \mathrm{IU} / \mathrm{ml}$ for humans was considered as a

18 cut-off for rabies immunization [1].

The results were evaluated in comparison between the different groups.

20 Statistical analysis were performe using Kruskall Wallis, Fisher test and Qui square

21 considering $\mathrm{p}<0,05$ significant.

23 Results 
The level of antibodies titers, 48 hours after birth, in the groups of calves were

2 directly correlated to the maternal titer, presenting all groups of calves similar results

3 and not significant statistical difference (Figure 1 and table 1).

4

5

6

7

8

9

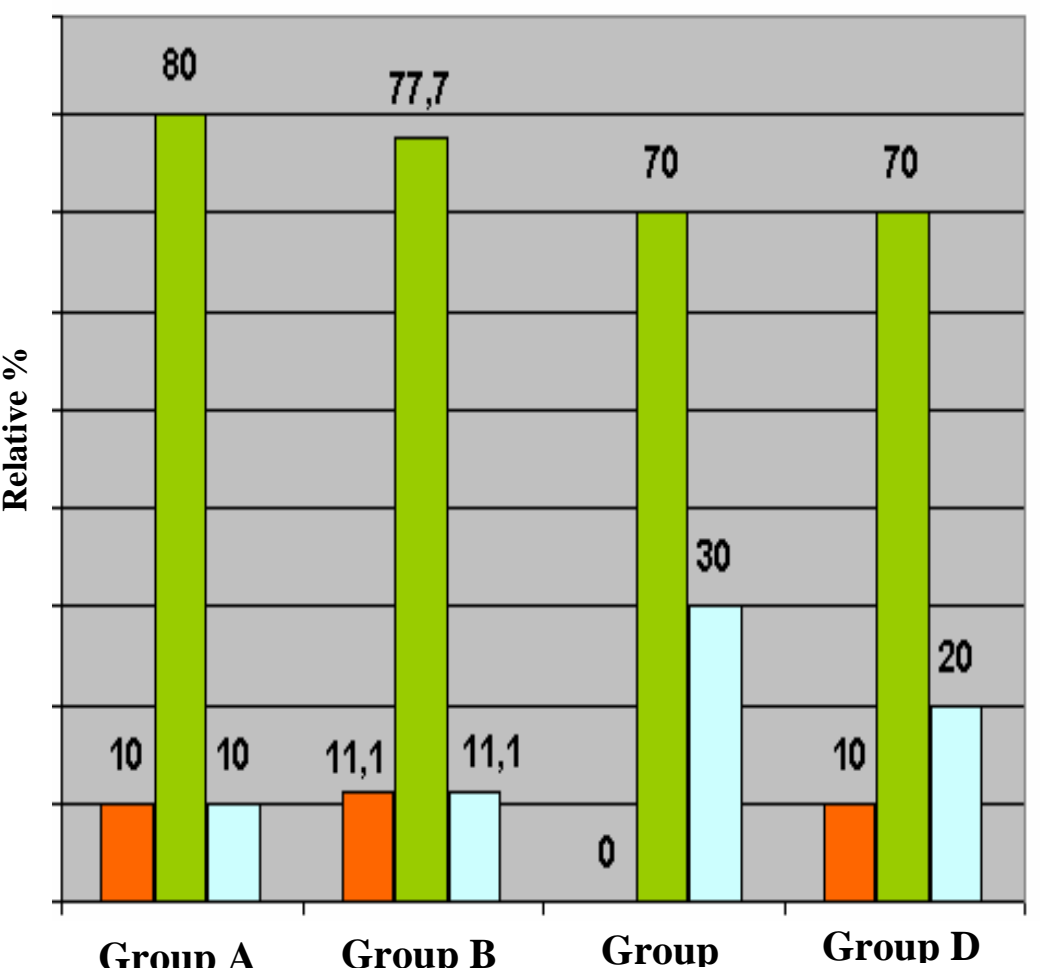

Calves with title:

Smaller than the maternal title titl Same to the maternal title

Larger than the maternal title

Figure 1- Variation distribution ( in \%) of antirabies neutralizing antibodies in calves, 48 hours after birth, correlated to maternal titers according to vaccinal age and status.

Table 1 - Descritive variation (\%) of antirabies antibodies titers presented by calves 48hours after birth

\begin{tabular}{|c|c|c|c|c|c|}
\hline & \multicolumn{4}{|c|}{ Age at vaccination } & \multirow[b]{2}{*}{$p^{(*)}$} \\
\hline & $\begin{array}{c}\text { Not } \\
\text { vaccinated }\end{array}$ & $\begin{array}{c}\text { Vaccinated to } \\
2 \text { months }\end{array}$ & $\begin{array}{l}\text { Vaccinated to } \\
4 \text { months }\end{array}$ & $\begin{array}{c}\text { Vaccinated to } \\
6 \text { months }\end{array}$ & \\
\hline $\begin{array}{l}\text { Median } \pm \\
\text { standard } \\
\text { deviation }\end{array}$ & $0,80 \pm 13,5$ & $8,3 \pm 35,2$ & $9,7 \pm 15,6$ & $5,8 \pm 20,8$ & \multirow[t]{2}{*}{0,576} \\
\hline $\begin{array}{c}\text { Median } \\
\text { (Quartíles) }\end{array}$ & $\begin{array}{c}0,0(0,0 ; \\
0,0)\end{array}$ & $0,0(0,0 ; 0,0)$ & $\begin{array}{c}0,0(0,0 ; \\
32,5)\end{array}$ & $0,0(0,0 ; 8,1)$ & \\
\hline
\end{tabular}


When considered the immune response after the vaccination and revaccination

2 in different ages statistical significant differences were observed between the groups

3 considering the antibodies titers on the day of first vaccination compared to 48 hours of

4 birth; 15 days post re-vaccination (PV2) compared to the day of vaccination and re-

5 vaccination and 12 months post birth compared to first vaccine day. Significant

6 statistical results are presented in table 2 and Figure 2.

7

8 Table 2 - Comparison between the age in the first vaccination correlated to serological

9 titer

\begin{tabular}{|c|c|c|c|c|}
\hline \multirow{2}{*}{ Variation (\%) } & \multicolumn{3}{|c|}{ Age in the first vaccination } & \multirow{2}{*}{$p^{(*)}$} \\
\hline & 2 month $(n=9)$ & 4 month $(n=10)$ & 6 month $(n=10)$ & \\
\hline Birth x Vaccine & $0,0(-50,5 ; 0,0) \mathbf{a}$ & $-78,3(-87,7 ;-43,6) \mathbf{b}$ & $-62,3(-84,7 ;-46,7) \mathbf{b}$ & $0,008^{(1 a)}$ \\
\hline Vaccine x PV1 (15 days post vaccine) & $-23,1(-43,0 ; 0,0) \mathbf{a}$ & $-17,5(-38,8 ; 7,5) \mathbf{a}$ & $30,0(-20,9 ; 116,3) \mathbf{a}$ & 0,196 \\
\hline PV1x Revaccine (15 days post PV1) & $0,0(-46,0 ; 0,0) \mathbf{a}$ & $53,8(-29,8 ; 151,9) \mathbf{a b}$ & $155,8(-5,8 ; 715,4) \mathbf{b}$ & $0,034^{(1 b)}$ \\
\hline Vaccine $x$ Revaccine (30 days post vaccine) & $-24,5(-71,3 ;-11,5) \mathbf{a}$ & $0,0(-37,8 ; 182,5) \mathbf{a b}$ & $132,5(24,4 ; 334,6) \mathbf{b}$ & $0,002^{(1 c)}$ \\
\hline Revaccine x V2 (15 days post revaccine) & $32,5(0,0 ; 318,9) \mathbf{a}$ & $307,7(-0,95 ; 430,0) \mathbf{a}$ & $16,2(0,0 ; 132,5) \mathbf{a}$ & 0,257 \\
\hline $\begin{array}{l}\text { PV2 x } 1 \text { month post revaccine (30 days post } \\
\text { PV2) }\end{array}$ & $0,0(-56,1 ; 0,0) \mathbf{a}$ & $-50,5(-75,5 ; 0,0) \mathbf{a}$ & $-12,3(-24,5 ; 0,0) \mathbf{a}$ & 0,398 \\
\hline $\begin{array}{l}\text { Revaccine x } 1 \text { month post revaccine ( } 30 \\
\text { days post revaccine) }\end{array}$ & $32,5(0,0 ; 100,0) \mathbf{a}$ & $30,0(0,0 ; 151,9) \mathbf{a}$ & $0,0(-6,1 ; 37,1) \mathbf{a}$ & 0,201 \\
\hline $\begin{array}{l}1 \text { month post revaccine } \mathrm{x} 12 \text { months post } \\
\text { birth }\end{array}$ & $0,0(-55,2 ; 15,0) \mathbf{a}$ & $77,3(-29,7 ; 207,7) \mathbf{a}$ & $16,2(0,0 ; 32,5) \mathbf{a}$ & 0,170 \\
\hline Vaccine $\mathrm{x} 12$ months post birth & $-24,5(-58,8 ; 0,0) \mathbf{a}$ & $203,8(-6,1 ; 451,3) \mathbf{b}$ & $165,0(131,9 ; 715,4) \mathbf{b}$ & $0,002^{(1 d)}$ \\
\hline Revaccine $\mathrm{x} 12$ months post birth & $0,0(-29,8 ; 66,3) \mathbf{a}$ & $186,3(22,5 ; 301,9) \mathbf{a}$ & $16,3(0,0 ; 116,3) \mathbf{a}$ & 0,115 \\
\hline
\end{tabular}

$11\left(^{*}\right)$ Kruskal-Wallis test for independent samples. Descritive resume in median and quartis.

$12 \mathrm{PV} 1=15$ days post vaccination $\quad \mathrm{PV} 2=15$ days post revaccination

13

14 
2

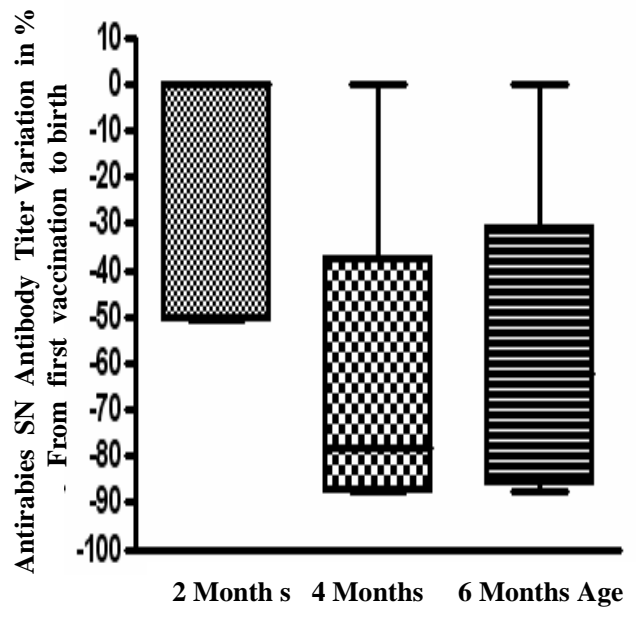

(1a)

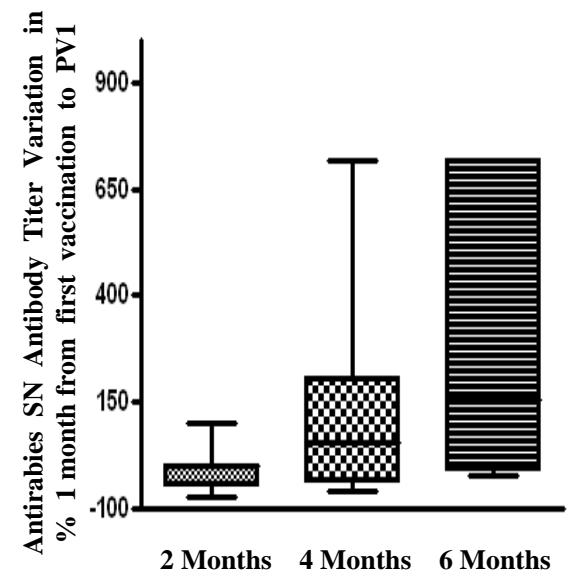

(1b)

3

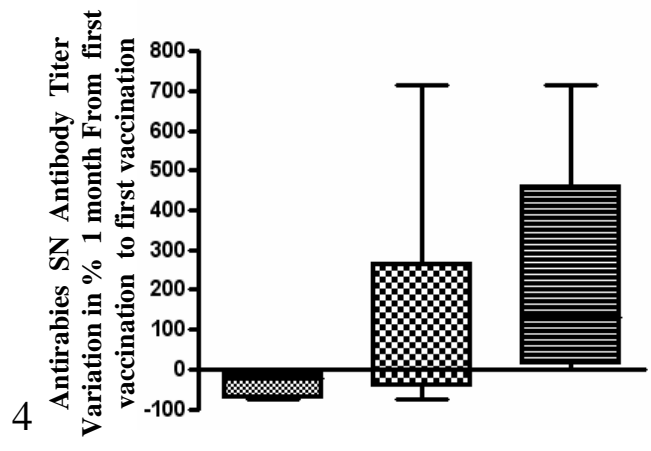

5

6

7

8 Figure 2 - Distribution, in percentage of variation, of seraneutralizing antibodies titers:

9 (1a) First vaccination correlated to birth (1b) one month from first vaccination to PV1,

10 (1c) 30 days post first vaccination to first vaccination (1d) 12 months post birth 11 correlated to first vaccination

12

14 presented in table 3 . The 15 days post vaccination $33.3 \%$ of calves vaccinated to two

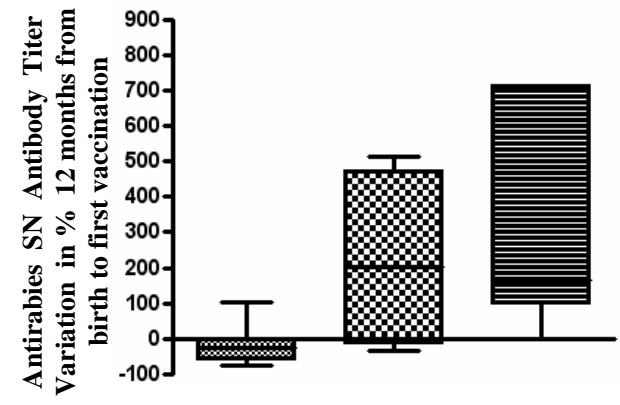

2 Months 4 Months 6 Months

(1d) (1c) 
1 months were unprotected while in vaccinated groups with four months and six months

$270 \%$ and 60\% were, respectively, unprotected. After revaccination (booster), in calves

3 vaccinated to two months, $11,1 \%$ were unprotected in relation to vaccinated at four

4 months and six months of age, in which all animals were protected. Statistically

5 significant difference was not observed between the groups ( $\mathrm{p}>0,05)$.

612 months after the birth, $44.4 \%$ of calves vaccinated for the first time at two

7 months of age were unprotected while the percentage of unprotected calves vaccinated

8 to four months was $20 \%$ and all calves vaccinated at six months were protected.

9 Significant difference was observed in the group vaccinated at 2 month age compared

10 to the group vaccinated at six months of age $(p=0,032)$, however, there was no

11 significant difference between the groups vaccinated at two and four months of age ( $\mathrm{p}=$

$120,349)$ and between the groups vaccinated at four and six months of age $(p=0,473)$. 
1 Table 3 - Comparison between the age in the first vaccination correlated to percentage

2 of unprotected calves (titer $<0,5 \mathrm{UI} / \mathrm{mL}$ )

\begin{tabular}{|c|c|c|c|c|}
\hline \multirow[b]{2}{*}{ Momento } & \multicolumn{4}{|c|}{ Age at vaccination } \\
\hline & $\begin{array}{l}\text { Unvaccinated } \\
(n=10)\end{array}$ & $\begin{array}{c}2 \text { month } \\
(n=9)\end{array}$ & $\begin{array}{l}4 \text { month } \\
(n=10)\end{array}$ & $\begin{array}{l}6 \text { month } \\
(n=10)\end{array}$ \\
\hline 48hours post Birth & 0,0 & 0,0 & 0,0 & 0,0 \\
\hline 1th month & 0,0 & 0,0 & 0,0 & 0,0 \\
\hline 2th month & 20,0 & 11,1 & 0,0 & 10,0 \\
\hline 3th month & 40,0 & 44,4 & 50,0 & 30,0 \\
\hline 4th month & 40,0 & 33,3 & 70,0 & 60,0 \\
\hline 5th month & 60,0 & 44,4 & 70,0 & 60,0 \\
\hline 6th month & 100,0 & 66,7 & 40,0 & 80,0 \\
\hline 7th month & 100,0 & 77,8 & 70,0 & 20,0 \\
\hline 8th month & 90,0 & 44,4 & 30,0 & 10,0 \\
\hline 9th month & 40,0 & 22,2 & 20,0 & 0,0 \\
\hline 10th month & 40,0 & 0,0 & 20,0 & 0,0 \\
\hline 11th month & 20,0 & 33,3 & 0,0 & 0,0 \\
\hline 12th month & 10,0 & $44,4 \mathbf{a}$ & $20,0 \mathbf{a b}$ & $0,0 \mathbf{b}$ \\
\hline PV1 & & $33,3 \mathbf{a}$ & 70,0 a & 60,0 a \\
\hline PV2 & & $11,1 \mathbf{a}$ & $0,0 \mathbf{a}$ & $0,0 \mathbf{a}$ \\
\hline
\end{tabular}
no significant difference in median of antibodies between all groups in the birth until the

7 age of two months. seraneutralizing antibodies titers less than $0,5 \mathrm{UI} / \mathrm{mL}$ were observed

8 in unvaccinated calves from 5 to 8 month; in vaccinated at two months, from 6 to 8

9 month and in the vaccinated group at four months the period of unprotection was

10 observed to 4 to 7 months and vaccination to the group corresponding to six months of 11 age, this situation was prominently 4 to 6 months. AcSN titles increase occurred in all 12 groups from the 9 months. 
1 Table 5 - Titers of anti-rabies neutralizing antibodies in unvaccinated and vaccinated

2 calves to two, four and six months of age in different times (values presented in median

3 and quartiles).

\begin{tabular}{cccccccccccccc}
\hline \multirow{2}{*}{ Moment } & \multicolumn{3}{c}{ Unvaccinated } & \multicolumn{3}{c}{ 2 months } & \multicolumn{3}{c}{ 4 months } & \multicolumn{3}{c}{ 6 months } \\
& $\mathbf{Q 1}$ & Median & 3Q & $\mathbf{Q 1}$ & Median & 3Q & Q1 & Median & 3Q & Q1 & Median & 3Q \\
\hline 48 hours & 1,06 & 1,06 & 1,06 & 1,06 & 1,06 & 1,06 & 1,06 & 1,06 & 1,06 & 1,06 & 1,06 & 1,06 \\
post birth & & & & & & & & & & & \\
1th month & 1,06 & 1,06 & 1,06 & 1,06 & 1,06 & 1,06 & 1,06 & 1,06 & 1,06 & 0,87 & 1,06 & 1,06 \\
2th month & 0,80 & 0,80 & 1,06 & 0,52 & 1,06 & 1,06 & 0,80 & 1,06 & 1,06 & 0,66 & 1,06 & 1,06 \\
3th month & 0,40 & 0,68 & 1,00 & 0,20 & 0,80 & 0,80 & 0,40 & 0,60 & 0,80 & 0,43 & 0,67 & 1,00 \\
4th month & 0,30 & 0,53 & 0,73 & 0,40 & 1,06 & 1,06 & 0,15 & 0,23 & 0,50 & 0,20 & 0,23 & 0,73 \\
5th month & 0,13 & 0,26 & 0,73 & 0,40 & 0,53 & 0,80 & 0,22 & 0,26 & 0,50 & 0,20 & 0,26 & 0,80 \\
6th month & 0,13 & 0,13 & 0,18 & 0,26 & 0,40 & 0,80 & 0,30 & 0,52 & 0,93 & 0,15 & 0,40 & 0,40 \\
7th month & 0,13 & 0,13 & 0,18 & 0,13 & 0,20 & 0,26 & 0,20 & 0,26 & 0,90 & 0,60 & 0,93 & 1,06 \\
8th month & 0,13 & 0,13 & 0,13 & 0,13 & 0,53 & 1,06 & 0,43 & 0,80 & 1,00 & 0,80 & 0,93 & 1,06 \\
9th month & 0,26 & 0,80 & 1,06 & 0,53 & 1,06 & 1,06 & 0,53 & 1,06 & 1,06 & 1,06 & 1,06 & 1,06 \\
10th month & 0,26 & 1,06 & 1,06 & 1,06 & 1,06 & 1,06 & 0,60 & 1,06 & 1,06 & 1,06 & 1,06 & 1,06 \\
11th month & 0,80 & 1,06 & 1,06 & 0,26 & 1,06 & 1,06 & 1,06 & 1,06 & 1,06 & 1,06 & 1,06 & 1,06 \\
12 month & 0,66 & 1,06 & 1,06 & 0,26 & 0,80 & 1,06 & 0,80 & 0,80 & 1,06 & 1,06 & 1,06 & 1,06 \\
\hline
\end{tabular}

4

5

6 Discussion

7

8

9 and correlated to the titer of their calves. The results obtained showed the presence of

10 neutralizing antibodies higher than $0,5 \mathrm{UI} / \mathrm{mL}, 48$ hours after the birth of their calves,

11 in all revaccinated cows. Different results were obtained by Geronutti (2002) that

12 studied in your research cows first vaccinated against rabies, also in the final period of

13 gestation. The author reported absence of protecting titer in nine (35, 7\%) of 30 cows

14 evaluated after the birth of calves and justifies the results as possible vaccination failure

15 due to a single dose of vaccine, in agreement with the work carried out by Albas et al., 
1 (1998) that reinforced the need of a booster to induce persistent titers of antibodies in

2 vaccinated animals.

Some researchers also reported similar results, since the immune response

4 induced by only one vaccine did not induce high titers of antibodies [28,32,27,23].

5 However, when booster are done, titers become significantly higher (Albas et al., 1998;

6 Oliveira et al., 2000; Albas et al., 2006), results, consistent with the observed in our

7 research, evaluating revaccinated cows.

Higher or similar antibodies titers have been observed in calves comparatively to

9 titers of their respective mothers, 48 hours after birth and colostrum ingestion,

10 indicating the transfer of colostral antibodies in all lots of animals. These results are

11 contrary to Bunn (1988) and Geronutti (2002), when assessing the transfer of colostral

12 antibodies in calves born from first vaccinated cows. They observed that the titer of

13 calves was extremely lower and not correlated with the mother titer after the birth,

14 probably due to one dose of anti-rabies vaccine only.

15 Colostral antirabies antibodies titers from birth until 4th month were observed

16 in all lots of calves studied in this work, in disagreement to Geronutti (2002) that found

17 antibodies titers until 30 days to 60 days of age in all lots of calves studied born from

18 prime vaccinated cows reinforcing the need and importance of maternal revaccination

19 for adequate immunity transfer via colostrum to their descendants.

20 They are also in disagreement to Arnold et al, (1973), that observed maternal 21 antibodies against rabies in 40 calves until the sixth month of life.

In the calves vaccinated at two months, SN titers at similar levels to presented

2348 hours after birth was observed on the day of vaccination, a result hat differed 
1 statistically from the other groups of calves vaccinated to four and six months of age,

2 who had a decreased of $78 \%$ and $62 \%$ in the titer 48 hs after birth until primo

3 vaccination, respectively.

Significant difference in antibody titers, was observed only 30 days after first vaccination and revaccination in calves vaccinated to two months and six months of age, being the group with four months of age in intermediate form between them, indicating interference of colostral antibodies in similar way in the immune response of calves first vaccinated at two and four month of age. However, after revaccination the immune response behaved similarly with increase in antibodies titers in all groups studied.

The responsiveness to vaccination even in the presence of colostral antibodies was observed by Zimmerman et al.(2006) who evaluate the protection against bovine viral diarrhea (BVDV) tipo1 in three groups of calves that ingested colostrum containing antibodies against BVDV (Group 1) and colostrum without BVDV antibodies (Group 2 and 3). The groups 1 and 2 were vaccinated against BVDV, while group 3 was vaccinated with placebo, both with five weeks of life, and challenged three and a half months after vaccination with the BVDV-2. strain The Group 3 have developed serious illness while calves from groups 1 and 2 have developed only a mild or without clinical signs of disease, concluding with the results that the live attenuated virus vaccine induced a protective immune response in calves, even when high levels of maternal antibodies were present.

The response to vaccination in calves with 2 months of age similar to calves vaccinated later, observed in this experiment, can be also explained by recent works demonstrating that young calves vaccinated in presence of maternal immunity are able 
1 to show evidence of cellular immunity, and even will display an memory response for

2 protection when exposed to the same antigen later in life [9]. Although the immune

3 system is able to give different degrees of protection, it is this combination of passive

4 and active immunity that together provides protection, often in the form of reduced the

5 severity of the disease for the newborn [10].

6 In this work, calves vaccinated to two months of age, remain with protective

7 levels of anti-rabies antibodies until de $6^{\text {th }}$ month of life, in contrast to found Geronutti

8 (2002) that noted antibodies titers below $0,5 \mathrm{UI} / \mathrm{mL}$ at in calves vaccinated to two

9 months of age born from prime vaccinated dams.

10 The group of animals unvaccinated, and a vaccinated to four and six months had

11 a decrease in antibodies titers considered protectives from the 4th month of life, while in

12 the vaccinated group to two months began in the 6th month, enabling these animals

13 longer period of protection, aspect very in endemic and epidemic areas of the disease.

14 These results are in agreement with Geronutti (2002) who observed absence of

15 protective antibody levels at six months in calves vaccinated to two months of age, born

16 from cows prime vaccinated against rabies; while in the groups vaccinated at four and

17 seven month of age this lack of protection was observed to four and six months of age.

In all vaccinated calves groups, in this research, there was no satisfactory

19 serological response to first vaccination 15 days after it, but was a significant increase in

20 the titers of seraneutralizing antibodies 30 days after the same and 15 days after

21 revaccination. This result was observed mainly in group vaccinated to 6 months of age.

Protective levels of seraneutralizing antibodies were not maintained in

23 vaccinated groups with two and four months, while in vaccinated animals to six months 
1 antibodies titers remained higher than other groups after revaccination until they reach

212 months of life, aspect also observed by Albas et al. (2005), that suggested the

3 antirabies vaccine with three doses being the booster indicated at 30 and 180 days after

4 the first vaccination.

5

6 beings by the World Health Organization [34].

7 exposed to disease. especially in endemic areas.

Longer period of lack of protection was observed in unvaccinated a calf that was observed during the period from five to eight months making those animals

In calves vaccinated with two months of age, the presence titer not protective was observed in the 6th and 7th month of life; in group vaccinated to four months this period ranged between the 4th and 7th month and in the group vaccinated to six months, between four and six months. This period is lower that one found by Geronutti (2002) where all animals born from cows prime vaccinated were born without titers considered protectors and maintained until the three month, five month and six month old respectively for vaccinated groups to two, four and six months of age.

We can thus observe that calves born from revaccinated dams, vaccinated to two months of age, had a shorter period of lack of protection against rabies virus in relation to other groups, providing an early immunity against rabies, aspect quite interesting

Considering the age of the first vaccination in relation to the percentage of unprotected animals, we could observe that 12 months after the birth, $44.4 \%$ of calves vaccinated for the first time at two months were unprotected while the percentage 
1 observed in calves vaccinated to four months was $20 \%$, and none of the vaccinated

2 animal to six months was not protected. This result demonstrate at 12 months of age, the

3 vaccinated animals to six months had higher degree of protection of first vaccination,

4 when compared with the calves vaccinated with two months of age, while the

5 vaccinated to four months was intermediate between them, indicating colostral

6 antibodies interference in younger animals born from revaccinated dams and the need of

7 booster doses as stated by other researchers $[1,21,4]$.

8 Thus the results demonstrated that revaccination against rabies, during

9 pregnancy, induces neutralizing antibodies titers in protectors levels transferred directly

10 to calves through colostrum and these antibodies remains for a variable period of three

11 to four months in calves born from cows revaccinated during pregnancy contrarily to

12 mothers first vaccinated that presented and transferred lower and less persistent titers of

13 antibodies to their calves

14 The results of this experiment demonstrated a response to antirabies vaccination,

15 although not identical, similar in all groups of calves vaccinated with two, four and six

16 months of life born from revaccinated mothers, been compulsory the booster dose and

17 annual revaccination.

18 These same results were observed by Geronutti (2002) in prime vaccinated 19 cows. The evidence of a similar response in calves born from vaccinated and 20 revaccinated dams demonstrates the viability of vaccination of younger animals in 21 antirabies vaccine protocols independently of maternal vaccinal status when necessary. 


\section{Bibliographic references}

6

7 [1] Albas, A.; Pardo, P.E.; Gomes, A.A.B.; Bernardi, F.; Ito F.H. Effect of a booster-

8 dose of rabies vaccine on the duration of virus neutralizing antibody titers in bovines.

9 Rev. Soc. Bras. Med. Trop., v.4, p.367-371, 1998.

10 [2] Albas, A.; Fontolan, O.L.; Pardo, P.E.; Bremer Neto, H. Resposta imune humoral 11 em bovinos vacinados contra a raiva em Presidente Prudente, SP, Brasil. Arq. Inst. 12 Biol., v.71, supl., p.1-749, 2004.

13 [3] Albas, A.; Pardo, P.E.; Bremer Neto, H.; Gallina, N.M.F.; Mourão Fuches, R.M.; 14 Sartori, A. Vacinação antirrábica em bovinos: comparação de cinco esquemas vacinais. 15 Arq. Inst. Biol., v.72, p153-159, 2005.

16 [4] Albas, A.; Fontolan, O.L.; Pardo, P.E.; Bremer Neto, H.; Sartori, A. Interval 17 between first dose and booster affected antibody production in cattle vaccinated against 18 rabies. J. Venom. Anim. Toxins incl. Trop. Dis., v.12, n.3, p.476-486, 2006.

19 [5] Arnold, R.M.; Salvatierra, J. Immunity against paralytic rabies in cattle following 20 vaccination with ERA vaccine under ranch conditions in Bolivia. Part of maternal 
1 antibody on the success of vaccination of calves of different ages. Trop. Anim. Health

2 Prod., v.5, p.6-11, 1973.

3 [6] Atanasiu, P. Quantitative assay and potency test of antirabies serum and

4 immunoglobulin. WHO Monogr. Serv., v.23, n.314, p. 314-318, 1973.

5 [7] Bunn, T.O. Vaccines and vaccination of domestic animals. In: Campbell, J.B.;

6 Charlton, K.M. Rabies. Boston: Kluwer, 1988. v.2, p.321-333.

7 [8] Champpuis, G. Neonatal immunity and immunization in early age: lessons from 8 veterinary medicine. Vaccine, v.16, n.13, p.1468-1472, 1998.

9 [9] Chase, C.C.L.; Hurley, D.J.; Reber, A.J. Neonatal immune development in the calf 10 and its impact on vaccine response. Vet. Clin. Food Anim., v.24, p.87-104, 2008.

11 [10] Cortese, V.S. Neonatal Immunology. Vet. Clin. Food Anim., v. 25, p. 221-227, 122009.

13 [11] Elizondo-Salazar, J.A.; Heinrichs, A.J. Review: Heat Treating Bovine Colostrum.

14 Profes. Anim. Sci.. v. 24, p 530-538, 2008.

15 [12] Favoretto, S.R.; Carrieri, M.L.; Tino, M.S.; Zanetti, C.R.; Pereira, O.A.C. 16 Simplified fluorescent inhibition microtest for the titration of rabies neutralizing 17 antibodies. Rev. Inst. Med. Trop. São Paulo, v.35, n.2, p.171-175, 1993. 
1 [13] Fulton, R.W.; Briggs, R.E.; Payton, M.E.; Confira, A.W.; Salik, J.T.; Ridpath, J.F.;

2 et al. Maternally derived humoral immunity to bovine viral diarrhea virus (BVDV) 1a,

3 BVDV 1b, BVDV 2, bovine herpesvirus-1, parainfluenza-3 virus bovine respiratory 4 syncytial virus, Mannheimia haemolytica and Pasteurella multocida in beef calves,

5 antibody decline by half-life studies and effect on response to vaccination. Vaccine, $6 \quad$ v.22, p.643-649, 2004.

7 [14] Geronutti, L.M. Vacinação antirrábica em bezerros: resposta imune humoral e 8 interferência de anticorpos colostrais. 2002. 83f. Dissertação (Mestrado) - Faculdade de 9 Medicina Veterinária, Universidade Estadual Paulista, Botucatu.

10 [15] Kotait, I.; Carrieri, M.L.; Takaoka, N.Y. RAIVA: aspectos gerais e clínica. São 11 Paulo: Instituto Pasteur, 2009. Manuais, 8. 49p.

12 [16] Langohr, I.M.; Irigoyen, L.F.; Lemos, R.A.A.; Barros, C.S.L. Aspectos 13 epidemiológicos e clínicos e distribuição das lesões histológicas no encéfalo de bovinos 14 com raiva. Ciênc. Rural, v.33, p.125-131, 2003.

15 [17] Lemos, R.A.A.A.; Brum, K.B.; Mori, A.E.; Bonilha, M.M.; Katayama, K.A.; 16 Angeves, G.M.; et al. Doenças caracterizadas por sintomatologia nervosa em bovinos 17 em Mato Grosso do Sul. In: Barros, C.S.L.; Lemos, R.A.A.; Cavallero, J.C.M. (Eds.). Manual de procedimentos para diagnóstico histopatológico diferencial da encefalopatia espongiforme bovina (BSE). São Paulo: Lemos, 2001. p.31-48. 
1 herbívoros na região Nordeste do Brasil. Pesqui. Vet. Bras., v.25, n.4, p.250-264, 22005.

3 [19] Morein, B.; Abusugra, I.; Blomqvist, G. Immunity in neonates. Vet. Immunol.

4 Imunopathol., v.87, p.207-213, 2002.

5 [20] Mori, A.E.; Lemos, R.A.A.; Kadri, A. Raiva. In: Lemos, R.A.A. (Ed.). Botulismo,

6 meningoencefalite por herpesvirus tipo 5 , poliencefalomalacia e raiva. Campo

7 Grande: UFMS, 2004. p.63-82.

8 [21] Oliveira, A.N.; Andrade, M.C.R.; Silva, M.V.; Moura, W.C.; Contreiras, E.C.

9 Immune response in cattle vaccinated against rabies. Mem. Inst. Oswaldo Cruz, v.95, 10 n.1, p.83-88, 2000.

11 [22] Organization Panamericana de La Salud. Boletín de vigilancia epidemiológica de

12 la rabia en las Américas. Rio de Janeiro: Panaftosa, 2004. v.36, 40p.

13 [23] Piza, A.T.; Pieri, K.M.S.; Lusa, G.M.; Caporale, G.M.M.; Terreran, 14 M.T.;Machado, L.A.;et al. Effect of contents and form of rabies glycoprotein on the 15 potency of rabies vaccination in cattle. Mem. Inst. Oswaldo Cruz, v.97, n.2, p.265$16 \quad 268,2002$.

17 [24] Porter, P. Immunoglobulins in bovine mammary secretions. Quantitatives changes 18 in early lactacion and by the neonatal calf. Immunology, v.23, p.225-229, 1972.

19 [25] Porter, P. Structural and functional characteristics of immunoglobulins of the 20 common domestic especies. Adv. Vet. Sci. Comp. Med., v.23, p.1-21, 1979. 
1 [26] Precausta, P.; Soulebot, J.P.; Bugand, M.; Brun, A.; Chappuis, G. Modelités de

2 production et immunité conférré par un vaccin antirabique inactivé provenant de culture

3 cellulaire. Comp. Immunol. Microbiol. Infect. Dis., v.5, p.217, 1982.

4 [27] Queiroz da Silva, L.H.; Cardoso, T.C.; Perri, S.H.V.; Pinheiro, D.M.; Carvalho, C.

5 Pesquisa de anticorpos antirrábicos em bovinos vacinados da região de Araçatuba, SP.

6 Arq. Inst. Biol., v.70, n.4, p.407-413, 2003.

7 [28] Silva, C.R.; Caporale, G.M.M.; Gonçalves, C.A.; Targueta, M.C.; Comin, F.;

8 Zanetti, R.; et al. Antibody response in cattle after vaccination with inactivated and

9 attenuated rabies vaccines. Rev. Inst. Med. Trop. São Paulo, v.42, n.2, p.95-98, 2000.

10 [29] Smith, J.S.; Yager, P.A.; Baer, G.M. A rapid reproducible test for determining 11 rabies neutralizing antibodies. Bull. WHO,v. 48, n.5, p. 535-541, 1973.

12 [30] Soulebot, J.P.; Précausta, P.; Brum, A.; Champpuis, G.; Jerré, J.; Javre, H.; et al. 13 Prophylaxie de la rage animale (ou vétérinaire) par un vaccin inactivé monovalent ou 14 associé. In: IABS CONGRESS VACCINATIONS IN THE DEVOLOPING 15 COUNTRIES, 15., 1978, La Guadeloup. Anais... La Guadeloup, 1978. p.389.

16 [31] Tizard,I.R. Veterinary Immunology. 7.ed. Philadelphia: W.B. Saunders, 2004. p. $17 \quad 221-233$.

18 [32] Umehara, O.; De Lucca Neto, D.; Moro, E.; Bernardi, F.; Ito, F.H.; Rodrigues,

19 C.A. Rabies virus neutralizing antibody profile in cattle vaccinated with inactivated 20 vaccine adjuvanted with either aluminium hydroxide alone or combined with avridine.

21 Arq. Inst. Biol., v.69, n.1, p.23-28, 2002. 
1 [33] Zimmerman, A.D.; Boots, R.E.; Valli, J.L.; Chase, C.C. Evaluation of protection

2 against virulent bovine viral diarrhea virus type 2 in calves that had maternal antibodies

3 and were vaccinated with a modified-live vaccine. J. Am. Méd. Assoc., v. 228, n. 11, p.

4 1757-1761, 2006.

5 [34] World Health Organization. Expert consultation on rabies. Geneva: World

6 Health Organization, 2008. (Technical Report Series, 840). Disponível em:

7 <http://www.who.int/rabies/epidemiology/en/>. Acesso em: 13 jun. 2009.

8

9

10

11

12 


\section{Guide for Authors}

Please follow these instructions carefully to ensure that the review and publication of your paper is as swift and efficient as possible. These notes may be copied freely.

Submission of manuscripts Online submission of papers The preferred mechanism of submission of manuscripts is electronic, by using the electronic submission tool at http://ees.elsevier.com/jvac. After registration, authors will be asked to upload their aricle and associated artwork. The submission tool will generate a PDF file to be used for the reviewing process. The submission tool generates an automatic reply which incorportates the manuscript number for future correspondence.Full instructions on how to use the online submission tool are available at the above web address.For those authors who cannot submit via EES, please refer to the appropriate Regional Editor to send a hardcopy to in accordance with the instructions below. It would be advised to email the Editor first as he/she may be able to assist with the (technical) submission problem. Authors must include a cover letter that contains the title, authors, a brief outline of the work's originality, desired section of publication, corresponding author's name, address, telephone and fax numbers (including country and city codes), and email address. Vaccine also publishes Review articles (which are usually invited by Reviews Editor), Letters and Reports, Book Reviews and Conference Reports. With the exception of Review articles, all other submissions should be sent to the Editor or one of the Regional Editors. Contributions are normally received on the understanding that they comprise original, unpublished material and are not being submitted for publication elsewhere. Translated material, which has not been published in English, will also be considered. All submissions should be accompanied by a written declaration, signed by all authors, that the paper has not been submitted for consideration elsewhere. Authors are solely responsible for the factual accuracy of their papers. The receipt of manuscript will be acknowledged.Any queries regarding accepted papers, proofs or offprints should be addressed to the Production Office, Vaccine, Elsevier Ltd, Bampfylde Street, Exeter EX1 2AH, UK. Telephone: +44 (1392) 251558. Fax: +44 (1392) 425370. 
Review process All contributions are read by two or more referees to ensure both accuracy and relevance, and revisions to the script may thus be required. On acceptance, contributions are subject to editorial amendment to suit house style. When a manuscript is returned for revision prior to final acceptance, the revised version must be submitted as soon as possible after the author's receipt of the referee's reports. Revised manuscripts returned after four months will be considered as new submissions subject to full re-review.

Suggestions for potential reviewers Authors are invited to provide the names, addresses, phone numbers and e-mail addresses of up to six potential reviewers. It would not be appropriate to nominate individuals that have had any input into the manuscripts submitted or any recent collaboration with the authors. The Editors may or may not take these suggestions into account during the reviewing process.

Copyright The submission of a paper will imply that, if accepted for publication, it will not be published elsewhere in the same form, in any language, without the consent of the Publisher. Before publication, authors are requested to assign copyright to Elsevier Ltd to sanction reprints and photocopies, and to authorize the reprinting of complete issues or volumes according to demand. It is the author's responsibility to obtain written permission to quote material that has appeared in another publication.

Preparation of scripts You should write in clear and concise English. Spelling should follow the Oxford English Dictionary. Authors whose native tongue is not English are assured that inhouse editorial attention to their contributions will improve clarity and acceptability to readers. Please double space all text and number every sheet of paper. Authors are responsible for ensuring that all manuscripts (whether original or revised) are accurately typed before final submission. Manuscripts will be returned to the authors with a set of instructions if they are not presented according to these Notes for Authors. Arrangements of papers You should arrange your contribution in the following order:1. Paper title, author's name, affiliation, full postal address, telephone and fax numbers and e-mail address. Affiliation and addresses of coauthors should be clearly indicated. The title should be short, specific and informative. 2. A selfcontained abstract of approximately 100 words (on a separate sheet of paper), outlining in a single paragraph the aims, scope and conclusions of the paper; three keywords, for indexing purposes; abbreviated article title, for use as a running headline.3. The text, suitably divided under headings.4. Acknowledgements (if any).5. References (double spaced, and following the journal style).6. Appendix (if any). 7. Tables (each on a separate sheet).8. Captions to illustrations (grouped on a separate sheet or sheets).9. Illustrations, each on a separate sheet containing no text and clearly labelled with the journal title, author's name and illustration number. 
Style of text Subdivide your paper in the simplest way possible, consistent with clarity. The text should usually follow the standard sequence of Introduction, Materials and Method, Results and Discussion. Headings and subheadings for different sections of the paper should be clearly indicated and numbered 1., 2., 2.1, etc. Ensure that all figures and tables are mentioned in the text, and that all references are cited in number order. Note that trade names should have an initial capital letter. Units and abbreviations All measurements and data should be given in SI units, or if SI units do not exist, in an internationally accepted unit. If you use any symbol or unit that may not be generally recognized, please include an explanatory footnote the first time it is used, to help the referees, editors and readers. It is also helpful to identify Greek symbols by name in the margin the first time they appear. Abbreviations and acronyms should only be used for unwieldy terms and names which occur frequently in the manuscript. Abbreviations should be used consistently throughout the text, and must be clearly defined in full on first use. Mathematical and technical setting Detailed mathematical discussion should be placed in an appendix. Equations and formulae should be typewritten wherever possible. Equations should be numbered consecutively with Arabic numerals in parentheses on the right hand side of the page. Special symbols should be identified in the margin, and the meaning of all symbols should be explained in the text where they first occur. If you use several symbols, a list of definitions (not necessarily for publication) will help the editor. Type or mark mathematical equations exactly as they should appear in print. Journal style for letter symbols is as follows: variables, italic type (indicated by underlining); constants; roman type; matrices and vectors, bold type (indicated by wavy underlining).Preparation of supplementary data. Elsevier now accepts electronic supplementary material (e-components) to support and enhance your scientific research. Supplementary files offer the Author additional possibilities to publish supporting applications, movies, animation sequences, high-resolution images, background datasets, sound clips and more. Supplementary files supplied will be published online alongside th electronic version of your article in Elsevier Web products, including ScienceDirect: $\square$ http://www.sciencedirect.com. In order to ensure that your submitted material is directly usable, please ensure that data is provided in one of our recommended file formats. Authors should submit the material in electronic format together with the article and supply a concise and descriptive caption for each file. For more detailed instructions please visit our artwork instruction pages at $\mathrm{http}: / /$ www.elsevier.com/artworkinstructions

Tables Tables should be numbered consecutively in Arabic numerals, and given a suitable caption. All table columns should have an explanatory heading, and, where appropriate, units of measurements. Footnotes to tables should be typed below the table, and should be referred to by superscript letters. Avoid the use of vertical rules. Tables should not duplicate results presented elsewhere in the manuscript, e.g. in graphs. 
Illustrations All graphs, photographs, diagrams and other drawings (including chemical structures) should be referred to as Figures, and numbered consecutively in Arabic numerals. All illustrations must be clearly labelled with the journal title, author's name and figure number.

Illustrations should be provided in camera ready form, suitable for reproduction without retouching, and should be either $85 \mathrm{~mm}$ (one column width) or $176 \mathrm{~mm}$ wide (two column width). Wherever possible figures should fit one column and so may be photographically reduced, so please ensure that lines and labeling are sufficiently large to allow for any reduction in size. Please ensure that all artwork complies with these requirements. Please ensure that all illustrations within a paper are consistent in style and quality. A table is usually more effective than a graph or a paragraph of text for recording data. Graphs and line drawings The minimum amount of descriptive text should be used on graphs and drawings; label curves, etc., with single-letter symbols (i.e. a, b, c, etc.) and place descriptive matter in the figure caption. Scale grids should not be used in graphs unless required for actual measurements. Please use a selection of the following symbols on graphs:,$+ x$, (open square), (closed square), (open circle), (closed circle), (closed triangle), (upside down closed triangle). Graph axes should be labelled with the variable written out in full, along the length of the axis, with the unit in parentheses (for example, Length of sample $(\mathrm{mm})$ ). Lower case letters should be used throughout, with an initial capital letter for the first word only. If your illustrations are computer generated, please supply the blackest possible laser output. Photographs Supply four sets of black and white prints. If necessary, a scale should be marked on the photograph. Please note that photocopies of photographs are not acceptable. Colour reproduction is available if the author is willing to bear the additional reproduction and printing costs. Please contact the editorial office for details. A letter confirming the author's willingness to accept these costs should be sent with the revised manuscript. Authors should note that illustrations will not be returned unless specifically requested.

Colour illustrations with Colourful e-Product Submit colour illustrations as original photographs, high-quality computer prints or transparencies, close to the size expected in publication, or as $35 \mathrm{~mm}$ slides. Please make sure the artwork is in an acceptable format (TIFF, EPS, MS Office files) and is at the correct resolution. Polaroid colour prints are not suitable. If, together with your accepted article, you submit usable colour figures then Elsevier will ensure, at no additional charge, that these figures will appear in colour on the web (e.g., Science Direct and other sites) regardless of whether or not these illustrations are reproduced in colour in the printed version. For colour reproduction in print, you will receive information regarding the costs from Elsevier after receipt of your accepted article. For further information on the preparation of electronic artwork, please see ahttp://www.elsevier.com/artworkinstructions [Please note: Because of technical complications which can arise by converting colour figures to "grey scale" (for printed version should you not opt for colour in print) please submit in addition usable black and white prints corresponding to all the colour illustrations.] 
References In the text, references should be numbered consecutively within square brackets (e.g. [1]). If you cite a reference more than once in the text, use the same number each time. References in the reference list should accord with the system in Uniform requirements for manuscripts submitted to biomedical journals (N Engl J Med 1991;34:424-428). Please ensure that references are complete.Examples (journal [1], book [2] and book chapter [3]):[1] Marsano LS, West DJ, Chan I, Hesley TM, Cox J, Hackworth V, Greenberg RN. A two-dose hepatitis B vaccine regimen: proof of priming and memory responses in young adults. Vaccine 1998;16(6):624-29.[2] Sherlock S. Diseases of the Liver and Biliary System. London: Blackwell Scientific Publications, 1981.[3] Katz JM, Lu X, Galphin JC, Clements, JD. Heat-labile enterotoxin from Escherichia coli as an adjuvant for oral influenza vaccination. In: Brown LE, Hampson AW Webster RG, editors. Options for the Control of Influenza III. New York, Elsevier, 1996: 292-97.Please note that all authors should be listed when six or less; when seven or more list only the first six and add et al. Do not include references to personal communications, unpublished data or manuscripts in preparation or submitted for publication.

Proofs Correspondence and proofs for correction will be sent to the first named author unless otherwise indicated. Proofs should be checked carefully. Changes or additions to the edited manuscript cannot be allowed at this stage. Corrected proofs should be returned to the Publisher by airmail, and preferably also by fax, within two days of receipt.

Offprints and reprints The corresponding author at no extra cost, will be provided with a PDF file of the article via e-mail or, alternatively, 25 free paper offprints. The PDF file is a watermarked version of the published article and includes a coversheet with the journal cover image and a disclaimer outlining the terms and conditions of use. Extra copies of offprints, minimum 50 , can be ordered on the form sent out to you.

Author enquiries For enquiries relating to the submission of articles (including electronic submission where available) please visit this journal's homepage at http://www.elsevier.com/locate/vaccine. You can track accepted articles at http://www.elsevier.com/trackarticle and set up e-mail alerts to inform you of when an article's status has changed, as well as copyright information, frequently asked questions and more.Contact details for questions arising after acceptance of an article, especially those relating to proofs, are provided after registration of an article for publication.

Page Charges There are no page charges. 